\title{
Analysis of reactive bromine production and ozone depletion in the Arctic boundary layer using 3-D simulations with GEM-AQ: inference from synoptic-scale patterns
}

\author{
K. Toyota ${ }^{1,2}$, J. C. McConnell ${ }^{1}$, A. Lupu ${ }^{1}$, L. Neary ${ }^{1}{ }^{*}$, C. A. McLinden ${ }^{2}$, A. Richter $^{3}$, R. Kwok ${ }^{4}$, K. Semeniuk ${ }^{1}$, \\ J. W. Kaminski ${ }^{1}$, S.-L. Gong ${ }^{2}$, J. Jarosz ${ }^{1}$, M. P. Chipperfield ${ }^{5}$, and C. E. Sioris ${ }^{2}$ \\ ${ }^{1}$ Department of Earth and Space Science and Engineering, York University, Toronto, Ontario, Canada \\ ${ }^{2}$ Air Quality Research Division, Science and Technology Branch, Environment Canada, Toronto, Ontario, Canada \\ ${ }^{3}$ Institute of Environmental Physics, University of Bremen, Bremen, Germany \\ ${ }^{4}$ Jet Propulsion Laboratory, California Institute of Technology, Pasadena, California, USA \\ ${ }^{5}$ School of Earth and Environment, University of Leeds, Leeds, UK \\ *now at: Belgian Institute for Space Aeronomy (BIRA-IASB), Brussels, Belgium
}

Received: 2 October 2010 - Published in Atmos. Chem. Phys. Discuss.: 5 November 2010

Revised: 26 March 2011 - Accepted: 20 April 2011 - Published: 28 April 2011

\begin{abstract}
Episodes of high bromine levels and surface ozone depletion in the springtime Arctic are simulated by an online air-quality model, GEM-AQ, with gas-phase and heterogeneous reactions of inorganic bromine species and a simple scheme of air-snowpack chemical interactions implemented for this study. Snowpack on sea ice is assumed to be the only source of bromine to the atmosphere and to be capable of converting relatively stable bromine species to photolabile $\mathrm{Br}_{2}$ via air-snowpack interactions. A set of sensitivity model runs are performed for April 2001 at a horizontal resolution of approximately $100 \mathrm{~km} \times 100 \mathrm{~km}$ in the Arctic, to provide insights into the effects of temperature and the age (first-year, FY, versus multi-year, MY) of sea ice on the release of reactive bromine to the atmosphere. The model simulations capture much of the temporal variations in surface ozone mixing ratios as observed at stations in the high Arctic and the synoptic-scale evolution of areas with enhanced $\mathrm{BrO}$ column amount ("BrO clouds") as estimated from satellite observations. The simulated "BrO clouds" are in modestly better agreement with the satellite measurements when the FY sea ice is assumed to be more efficient at releasing reactive bromine to the atmosphere than on the MY sea ice. Surface ozone data from coastal stations used in this study are not sufficient to evaluate unambiguously the difference between the FY sea ice and the MY sea ice as a source of
\end{abstract}

bromine. The results strongly suggest that reactive bromine is released ubiquitously from the snow on the sea ice during the Arctic spring while the timing and location of the bromine release are largely controlled by meteorological factors. It appears that a rapid advection and an enhanced turbulent diffusion associated with strong boundary-layer winds drive transport and dispersion of ozone to the near-surface air over the sea ice, increasing the oxidation rate of bromide $\left(\mathrm{Br}^{-}\right)$in the surface snow. Also, if indeed the surface snowpack does supply most of the reactive bromine in the Arctic boundary layer, it appears to be capable of releasing reactive bromine at temperatures as high as $-10^{\circ} \mathrm{C}$, particularly on the sea ice in the central and eastern Arctic Ocean. Dynamically-induced $\mathrm{BrO}$ column variability in the lowermost stratosphere appears to interfere with the use of satellite $\mathrm{BrO}$ column measurements for interpreting $\mathrm{BrO}$ variability in the lower troposphere but probably not to the extent of totally obscuring "BrO clouds" that originate from the surface snow/ice source of bromine in the high Arctic. A budget analysis of the simulated air-surface exchange of bromine compounds suggests that a "bromine explosion" occurs in the interstitial air of the snowpack and/or is accelerated by heterogeneous reactions on the surface of wind-blown snow in ambient air, both of which are not represented explicitly in our simple model but could have been approximated by a parameter adjustment for the yield of $\mathrm{Br}_{2}$ from the trigger.

Correspondence to: $\mathrm{K}$. Toyota

(kenjiro.toyota@ec.gc.ca) 


\section{Introduction}

During the spring after complete darkness in the winter, boundary-layer air over Arctic sea ice and its surrounding coastal areas experiences a frequent occurrence of ozone depletion events (ODEs) from background levels ( 30$40 \mathrm{nmol} \mathrm{mol}^{-1}$ ) to below $5-10 \mathrm{nmol} \mathrm{mol}^{-1}$ and sometimes even below experimental detection limits $\left(\lesssim 1 \mathrm{nmol} \mathrm{mol}^{-1}\right)$ (Oltmans, 1981; Bottenheim et al., 1986, 2002, 2009; Solberg et al., 1996; Hopper et al., 1998; Tarasick and Bottenheim, 2002). The ODEs are generally accompanied by a significant increase in gaseous and/or particulate bromine concentrations (Barrie et al., 1988; Oltmans et al., 1989; $\mathrm{Li}$ et al., 1994). The detection of BrO radicals as high as $30 \mathrm{pmol} \mathrm{mol}^{-1}$ in the near-surface air provided compelling evidence for bromine radical chemistry that depletes ozone in several days (Hausmann and Platt, 1994; Tuckermann et al., 1997):

$\mathrm{Br}+\mathrm{O}_{3} \rightarrow \mathrm{BrO}+\mathrm{O}_{2}$

$\mathrm{BrO}+\mathrm{BrO} \rightarrow\left\{\begin{array}{l}2 \mathrm{Br}+\mathrm{O}_{2} \\ \mathrm{Br}_{2}+\mathrm{O}_{2}\end{array}\right.$

$\mathrm{Br}_{2}+h v \rightarrow 2 \mathrm{Br}$

The boundary-layer ODEs also take place over sea ice around the Antarctica (Yurganov, 1990; Murayama et al., 1992; Wessel et al., 1998; Tarasick and Bottenheim, 2002), where the increase of IO radicals to about $20 \mathrm{pmol} \mathrm{mol}^{-1}$ along with $\mathrm{BrO}$ radicals indicates a synergistic effect of bromine and iodine radical chemistry on the ozone loss (Kreher et al., 1997; Frieß et al., 2001, 2004; Saiz-Lopez et al., 2007; Schönhardt et al., 2008). In the Arctic, the impact of iodine radical chemistry has been found to be rather limited in spatial scale and in magnitude (Tuckermann et al., 1997; Schönhardt et al., 2008; Mahajan et al., 2010). Satellite measurements have revealed that areas with enhanced $\mathrm{BrO}$ column amount, called "BrO clouds", occur extensively in the polar regions of both hemispheres particularly during the spring (Chance, 1998; Richter et al., 1998; Wagner and Platt, 1998; Wagner et al., 2001). This has been interpreted normally as a consequence of reactive bromine release from a vast area of the polar ice/snow surface, but a recent study by Salawitch et al. (2010) pointed to convolutions from $\mathrm{BrO}$ variability above the near-surface boundary layer, especially that associated with dynamically-induced changes in the $\mathrm{BrO}$ column amount near the tropopause.

Heterogeneous chemistry plays a critical role for the formation of reactive bromine in the polar boundary layer. With a realization that the snowpack retains a significant amount of bromide $\left(\mathrm{Br}^{-}\right)$originated from seawater and accessible from the atmosphere especially when mediated by a wind pumping (McConnell et al., 1992), the following reactions have been proposed as key steps to a net release of bromine from the snowpack to the atmosphere (Tang and McConnell, 1996; Michalowski et al., 2000; Lehrer et al., 2004):

$$
\begin{aligned}
& \mathrm{HOBr}+\mathrm{Br}^{-} \stackrel{\mathrm{H}^{+}}{\rightarrow} \mathrm{Br}_{2}+\mathrm{H}_{2} \mathrm{O} \\
& \mathrm{BrONO}_{2}+\mathrm{Br}^{-} \rightarrow \mathrm{Br}_{2}+\mathrm{NO}_{3}^{-}
\end{aligned}
$$

where $\mathrm{HOBr}$ and $\mathrm{BrONO}_{2}$ are reproduced via gas-phase chemistry in the atmosphere and presumably in the snowpack interstitial air as well, subsequent to the photolysis of $\mathrm{Br}_{2}$ (Reaction R3) and the production of $\mathrm{BrO}$ via Reaction (R1):

$$
\begin{aligned}
& \mathrm{BrO}+\mathrm{HO}_{2} \rightarrow \mathrm{HOBr}+\mathrm{O}_{2} \\
& \mathrm{BrO}+\mathrm{NO}_{2}+\mathrm{M} \rightarrow \mathrm{BrONO}_{2}+\mathrm{M} .
\end{aligned}
$$

These reactions constitute an autocatalytic cycle of releasing bromine from the snowpack to the atmosphere, called "bromine explosion" (Wennberg, 1999), which continues until the production of $\mathrm{HOBr}$ and/or $\mathrm{BrONO}_{2}$ diminishes after ozone is depleted and is then taken over by the deposition of inactive bromine species perhaps in the form of gaseous $\mathrm{HBr}$ and particulate $\mathrm{Br}^{-}$back to the snowpack. The strong surface wind also generates drifting and/or blowing snow particles detached from the surface snowpack and thereby facilitates the bromine explosion via an increased exposure of the saline snow surface to ambient air in the near-surface boundary layer (Jones et al., 2009).

The chemistry of $\mathrm{Br}_{2}$ release from salty snow/ice (Reactions $\mathrm{R} 4-\mathrm{R} 5$ ) often involves $\mathrm{Cl}^{-}$, which is more abundant than $\mathrm{Br}^{-}$in seawater by about 650 times (as mole fraction) and also in the Arctic snowpack typically by 2 to 3 orders of magnitude (Simpson et al., 2005; Millero et al., 2008), to give $\mathrm{BrCl}$ as an initial step:

$$
\begin{aligned}
& \mathrm{HOBr}+\mathrm{Cl}^{-} \stackrel{\mathrm{H}^{+}}{\rightarrow} \mathrm{BrCl}+\mathrm{H}_{2} \mathrm{O} \\
& \mathrm{BrONO}_{2}+\mathrm{Cl}^{-} \rightarrow \mathrm{BrCl}+\mathrm{NO}_{3}^{-}
\end{aligned}
$$

followed by halogen inter-exchange reactions (Adams et al., 2002):

$\mathrm{BrCl}+\mathrm{Br}^{-} \leftrightarrows \mathrm{Br}_{2} \mathrm{Cl}^{-} \leftrightarrows \mathrm{Br}_{2}+\mathrm{Cl}^{-}$

A part of $\mathrm{BrCl}$ is released to ambient air before reacting with $\mathrm{Br}^{-}$in the snowpack and then undergoes photolysis to produce $\mathrm{Cl}$-atoms along with $\mathrm{Br}$-atoms (Michalowski et al., 2000; Foster et al., 2001; Spicer et al., 2002). The Cl-atoms account for a major part of the loss of hydrocarbons observed in the springtime Arctic boundary layer, but are believed to play a marginal role in ozone loss (Jobson et al., 1994; Solberg et al., 1996; Ramacher et al., 1999).

One of the outstanding questions about reactive halogen chemistry in the polar boundary layer is how the release of halogens from the natural saline snow/ice surface is facilitated at temperatures below the freezing point of water and brine. For instance, from the long-term record of 
ozonesonde data obtained at several Arctic stations, Tarasick and Bottenheim (2002) found boundary-layer ODEs (defined by $\left[\mathrm{O}_{3}\right]<10 \mathrm{nmol} \mathrm{mol}^{-1}$ ) only when local air temperatures dropped below $-20^{\circ} \mathrm{C}$, whereas Bottenheim et al. (2009), during "frozen-in" shipboard measurements in the ice-covered Arctic Ocean, observed partially depleted surface ozone levels (ca. $10 \sim 20 \mathrm{nmol} \mathrm{mol}^{-1}$ ) at local air temperatures as high as $-6^{\circ} \mathrm{C}$. Sander et al. (2006) suggested an essential role of low temperature conditions for activating the bromine chemistry in two ways: first, by carbonate precipitation from brine to titrate its alkalinity (more than $80 \%$ of carbonate originally contained in seawater is estimated to precipitate when cooled down to $-8^{\circ} \mathrm{C}$ ) so that the brine can be acidified by a relatively small amount of acidic gas uptake, and second, by shifting the equilibrium constants of Reactions (R10) towards the $\mathrm{Br}_{2}$ formation. Morin et al. (2008), however, argued that the carbonate precipitation should not reduce the alkalinity of brine as proposed by Sander et al. (2006) (see also a follow-up study by Sander and Morin, 2010). At least at temperatures above the freezing point of water, for the release of $\mathrm{Br}_{2}$ and/or $\mathrm{BrCl}$ to occur via uptake of gaseous $\mathrm{HOBr}$, aqueous salt solutions need to be acidified to pHs below 6.5 (Fickert et al., 1999). On the other hand, Adams et al. (2002) experimentally showed that the reactive uptake of $\mathrm{HOBr}$ onto frozen $\mathrm{NaBr} / \mathrm{NaCl}$ solution results in the $\mathrm{Br}_{2}$ and/or $\mathrm{BrCl}$ release below $-20^{\circ} \mathrm{C}$ even if the substrate is alkaline at room temperature before frozen.

Another important question that remains to be fully answered is how halide anions such as $\mathrm{Br}^{-}$are supplied to the surface snow and made accessible from the atmosphere across the polar regions. Fresh, growing sea ice entraps brine, which is expelled from the ice during congelation, and the salinity of brine increases with decreasing temperature (Steffen and DeMaria, 1996; Light et al., 2003). Some brine is also expelled onto the top of sea ice. Under some circumstances, the condensation of water vapor leads to a formation of intricate crystals called "frost flowers", which wick up salinity from the slurry surface of the sea ice and are then covered with drifting snow in several days (Perovich and Richter-Menge, 1994). It has been suggested that the frost flowers themselves, either bound to the sea ice or suspended in the air after wind abrasion, provide a major source of reactive bromine to the polar boundary layer (Rankin et al., 2002; Kaleschke et al., 2004). Kaleschke et al. (2004) proposed an algorithm to diagnose the potential coverage of frost flowers (called "potential frost flower", or PFF) on sea ice across the polar regions by using satellite data of sea ice concentrations and objective analyses of large-scale surface air temperatures. Their algorithm predicts increased PFF values with decreasing surface air temperatures particularly below $-20^{\circ} \mathrm{C}$ for a given formation rate of open/refreezing leads in the sea ice. Simpson et al. (2007a), however, showed that the PFF data obtained by the Kaleschke et al. (2004) algorithm did not provide a good measure for locating the source of reactive bromine on Arctic sea ice to explain the origins of enhanced $\mathrm{BrO}$ columns measured from the ground at Barrow, Alaska. The age of sea ice as to whether it is first-year (FY) or multi-year (MY) can also be retrieved remotely from satellite (e.g., Kwok, 2004). According to Simpson et al. (2007a), the FY sea ice is a better indicator for locating the source region of reactive bromine than the PFF, presumably because salinity is generally higher on the FY sea ice than on the MY sea ice.

Readers may refer to thorough reviews by Simpson et al. (2007b) and Grannas et al. (2007) on a range of issues and findings regarding the ODEs and reactive halogen chemistry in the polar boundary layer as well as photochemistry in the snowpack releasing a variety of compounds to the atmosphere. The springtime bromine chemistry is also important for the geochemical cycle of mercury in the polar regions (see Steffen et al., 2008, for a review). In this study, we focus on the surface source problem with regard to the occurrence of high bromine levels and ODEs in the Arctic spring. By using a three-dimensional online air-quality model that incorporates bromine chemistry, it is shown that the ubiquitous occurrence of reactive bromine release initiated mainly on the FY sea ice accounts for surface ozone variability as observed at Arctic coastal stations and even the evolution of "BrO clouds" as seen from satellite reasonably well, and that they are altogether controlled by synoptic-scale meteorological forcing. We also look at a sensitivity of the simulation results on the choice of temperature below which reactive bromine release from the snow/ice surface is turned on in the model, to provide some insights into chemistry occurring in the snow across the Arctic.

\section{Model description}

GEM-AQ is an online air-quality model that incorporates gas-phase oxidant chemistry and size-resolved multicomponent aerosol modules into a Canadian weather forecast model, GEM (Global Environmental Multiscale model). It has been used for simulating the regional-scale transport and microphysical evolution of aerosols released from forest fires (O'Neill et al., 2006), the global distributions of HCN in the upper troposphere (Lupu et al., 2009), and the formation and transport of ozone in the lower troposphere during the summer 2006 heat wave in Europe (Struzewska and Kaminski, 2008). The model has been evaluated also from a perspective of global tropospheric chemistry (Kaminski et al., 2008). Unless otherwise noted, the present model configuration is the same as described in Kaminski et al. (2008).

\subsection{Numerical configuration}

An important feature of the host GEM model is that it allows global simulations with variable resolution grids by zooming a region of interest (Côté et al., 1998). In this study, we run the model employing a global variable grid with a reasonably 
Table 1. Gas-phase, heterogeneous (on aerosols), and photolysis reactions of bromine species added to GEM-AQ for this study. ${ }^{\mathrm{a}, \mathrm{b}}$

\begin{tabular}{|c|c|c|c|}
\hline No. & Reaction & Rate constant ${ }^{\mathrm{c}}$ & Reference \\
\hline \multicolumn{4}{|c|}{ Gas-phase reactions } \\
\hline G119 & $\mathrm{Br}+\mathrm{O}_{3} \rightarrow \mathrm{BrO}\left(+\mathrm{O}_{2}\right)$ & $k=1.7 \times 10^{-11} \exp (-800 / T)$ & 1 \\
\hline G120 & $\mathrm{BrO}+\mathrm{BrO} \rightarrow \mathrm{Br}+\mathrm{Br}\left(+\mathrm{O}_{2}\right)$ & $k=2.7 \times 10^{-12}$ & 1 \\
\hline G121 & $\mathrm{BrO}+\mathrm{BrO} \rightarrow \mathrm{Br}_{2}\left(+\mathrm{O}_{2}\right)$ & $k=2.9 \times 10^{-14} \exp (840 / T)$ & 1 \\
\hline G122 & $\mathrm{BrO}+\mathrm{NO} \rightarrow \mathrm{Br}+\mathrm{NO}_{2}$ & $k=8.7 \times 10^{-12} \exp (260 / T)$ & 1 \\
\hline G123 & $\mathrm{Br}+\mathrm{HO}_{2} \rightarrow \mathrm{HBr}\left(+\mathrm{O}_{2}\right)$ & $k=7.7 \times 10^{-12} \exp (-450 / T)$ & 1 \\
\hline G124 & $\mathrm{Br}+\mathrm{HCHO} \stackrel{\mathrm{O}_{2}}{\rightarrow} \mathrm{HBr}+\mathrm{CO}+\mathrm{HO}_{2}$ & $k=7.7 \times 10^{-12} \exp (-580 / T)$ & 2 \\
\hline G125 & $\mathrm{Br}+\mathrm{ALD} 2 \stackrel{\mathrm{O}_{2}}{\rightarrow} \mathrm{HBr}+\mathrm{MCO}_{3}$ & $k=1.8 \times 10^{-11} \exp (-460 / T)$ & 2 \\
\hline G126 & $\mathrm{OH}+\mathrm{HBr} \rightarrow \mathrm{Br}\left(+\mathrm{H}_{2} \mathrm{O}\right)$ & $k=5.5 \times 10^{-12} \exp (205 / T)$ & 1 \\
\hline G127 & $\mathrm{BrO}+\mathrm{NO}_{2}+\mathrm{M} \rightarrow \mathrm{BrONO}_{2}+\mathrm{M}$ & $\begin{array}{l}k_{0}=4.7 \times 10^{-31}(T / 300)^{-3.1}[\mathrm{M}] \\
k_{\infty}=1.8 \times 10^{-11}, F_{c}=0.4\end{array}$ & $1^{\mathrm{d}}$ \\
\hline G128 & $\mathrm{BrO}+\mathrm{HO}_{2} \rightarrow \mathrm{HOBr}\left(+\mathrm{O}_{2}\right)$ & $k=4.5 \times 10^{-12} \exp (500 / T)$ & 1 \\
\hline G129 & $\begin{array}{l}\mathrm{BrO}+\mathrm{MO}_{2} \stackrel{\mathrm{O}_{2}}{\rightarrow} \mathrm{HCHO}+0.75 \\
\times \mathrm{HOBr}+0.25 \times \mathrm{Br}+0.25 \times \mathrm{HO}_{2}\end{array}$ & $k=5.7 \times 10^{-12}$ & 3 \\
\hline \multicolumn{4}{|c|}{ Heterogeneous reactions on aerosols } \\
\hline G130 & $\mathrm{HOBr} \rightarrow 0.5 \times \mathrm{Br}_{2}$ & $\gamma=0.1$ & see Note ${ }^{\mathrm{e}}$ \\
\hline G131 & $\mathrm{BrONO}_{2} \rightarrow \mathrm{HOBr}+\mathrm{HNO}_{3}$ & $\gamma=0.1$ & see Note \\
\hline G132 & $\mathrm{HBr} \rightarrow 0.5 \times \mathrm{Br}_{2}$ & $\gamma=0.1$ & see Note ${ }^{\mathrm{e}}$ \\
\hline \multicolumn{4}{|c|}{ Photolysis reactions } \\
\hline P20 & $\mathrm{BrO}+\mathrm{h} v \rightarrow \mathrm{Br}+\mathrm{O}$ & & see Note $^{f}$ \\
\hline $\mathrm{P} 21$ & $\mathrm{Br}_{2}+\mathrm{h} v \rightarrow \mathrm{Br}+\mathrm{Br}$ & & see Note ${ }^{\mathrm{f}}$ \\
\hline $\mathrm{P} 22$ & $\mathrm{HOBr}+\mathrm{h} v \rightarrow \mathrm{Br}+\mathrm{OH}$ & & see Note $^{\mathrm{f}}$ \\
\hline P23 & $\mathrm{BrONO}_{2}+\mathrm{h} v \rightarrow \mathrm{Br}+\mathrm{NO}_{3}$ & & see Note ${ }^{f}$ \\
\hline
\end{tabular}

References: 1 Atkinson et al. (2007); 2 Atkinson et al. (2006); 3 IUPAC (2005).

a See Kaminski et al. (2008) for the list of other reactions included in GEM-AQ.

${ }^{b} \mathrm{ALD} 2=\mathrm{CH}_{3} \mathrm{CHO}$ and higher aldehydes, assumed to react as $\mathrm{CH}_{3} \mathrm{CHO} ; \mathrm{MCO}_{3}=\mathrm{CH}_{3} \mathrm{CO}_{3} ;$ and $\mathrm{MO}_{2}=\mathrm{CH}_{3} \mathrm{O}_{2}$.

${ }^{c}$ The unit of the rate constants for gas-phase reactions (G119-129) is $\mathrm{cm}^{3}$ molecule ${ }^{-1} \mathrm{~s}^{-1}$.

${ }^{d}$ See Atkinson et al. (2007) for the formulation of the pseudo-second-order rate constant of the termolecular reaction (G127).

${ }^{\mathrm{e}}$ Heterogeneous reactions on the aerosol surface where the first-order rate constants (in s ${ }^{-1}$ ) are calculated by the modified Fuchs-Sutugin equation as described in Gong et al. (2003) and by using an estimated reaction probability $(\gamma=0.1)$. However, the HBr loss rate via Reaction (G132) and the sum of the HOBr loss rate via Reaction (G130) and the $\mathrm{BrONO}_{2}$ loss rate via Reaction $(\mathrm{G} 131)$ are diagnosed before the numerical integration of chemical tendency equations and, if the former is greater than the latter (i.e., $k_{\mathrm{G} 132}[\mathrm{HBr}]>$ $\left.k_{\mathrm{G} 130}[\mathrm{HOBr}]+k_{\mathrm{G} 131}\left[\mathrm{BrONO}_{2}\right]\right)$, the rate constant for Reaction (G132) is scaled down so as to equalize the two diagnosed quantities.

${ }^{\mathrm{f}}$ Absorption cross sections and quantum yields as adopted by the MESSy/JVAL submodel (Jöckel et al., 2006) and based largely on DeMore et al. (1997).

high resolution over the Arctic Ocean and surrounding subarctic regions. It has $191 \times 150$ horizontal grid cells in total, among which $90 \times 90$ grid cells around the North Pole comprise a uniform core at the $0.88^{\circ} \times 0.88^{\circ}$ (approximately $100 \mathrm{~km} \times 100 \mathrm{~km}$ ) resolution and remaining grid cells spread outside the core by a stretching factor of 1.04 per grid southwards. The vertical grid consists of 28 levels and extends from the ground/sea surface to $10 \mathrm{hPa}$ in a hybrid p- $\sigma$ coordinate, containing 8 layers in the lowest $2 \mathrm{~km}$. The model accounts for large-scale advection, turbulent diffusion, convective transport, emissions, dry and wet deposition, chemical reactions and aerosol microphysics. Each sub-process is integrated at a time step of $1800 \mathrm{~s}$.

\subsection{Gas-phase and heterogeneous aerosol chemistry}

GEM-AQ has incorporated a chemical mechanism for gasphase oxidants modified from the Acid Deposition and Oxidant Model (ADOM) mechanism (Stockwell and Lurmann, 1989), which is originally designed for regional air-quality simulations, to permit extended applications to background tropospheric chemistry (Kaminski et al., 2008). The heterogeneous hydrolysis of $\mathrm{N}_{2} \mathrm{O}_{5}$ on aerosols has been also included, for which Canadian Aerosol Module, CAM (Gong et al., 2003), can provide online spatial distributions of five components of size-resolved aerosols, viz. sea salt (produced on the ice-free ocean), sulfate, black carbon, organic carbon, and dust. 
For this study, we add gas-phase chemistry and simplified heterogeneous aerosol chemistry of six inorganic bromine species, viz. $\mathrm{Br}, \mathrm{BrO}, \mathrm{Br}_{2}, \mathrm{HOBr}, \mathrm{BrONO}_{2}$ and $\mathrm{HBr}$ (Table 1). Chlorine chemistry is not included in the model. As mentioned in the Note e of Table 1 , the $\mathrm{Br}_{2}$ production in Reaction (G132) is assumed to be limited by the concurrent uptake of $\mathrm{HOBr}$ and $\mathrm{BrONO}_{2}$ onto aerosols so that the firstorder rate constant of $\mathrm{HBr}$ loss for Reaction (G132) is adjusted at every time step by diagnosing the availability of $\mathrm{HOBr}$ and $\mathrm{BrONO}_{2}$ from the gas phase. This adjustment procedure, taken together with a product assignment for Reaction (G130), serves as a numerically efficient means of approximating the competitive formation of $\mathrm{Br}_{2}$ and $\mathrm{BrCl}$ via Reaction (R10) in our simple scheme of bromine chemistry but without chlorine chemistry.

Among the five aerosol components that can be handled by CAM, only sulfate and sea salt are switched on in our present model runs for numerical efficiency and relevance to Arctic bromine chemistry (e.g., Fan and Jacob, 1992). The sea-salt aerosols are assumed to be unimportant as a source of halogens (e.g., Lehrer et al., 1997) and only to provide their surface for facilitating heterogeneous reactions along with the sulfate aerosols (cf. Vogt et al., 1996; Toyota et al., 2004; Yang et al., 2005). Simulated concentrations of sulfate and sea-salt aerosols are briefly evaluated against ground-level observations from selected Arctic sites (see Sect. S2 in the Supplement).

Zhao et al. (2008) developed another version of GEMAQ by taking a multiphase chemistry module from Sander et al. (2005) to simulate reactive halogen release from seasalt aerosols generated by a wind abrasion of frost flowers. It should be noted that the reaction scheme for halogen chemistry and the numerical approach employed in this study are somewhat different from those employed by Zhao et al. (2008).

\subsection{Emission, deposition, and air-snow/ice surface interactions of reactive bromine species}

We use a parameterization for the dry deposition of gaseous compounds to quantify the sink, and the source as explained below, of inorganic bromine species on various types of surface. GEM-AQ calculates dry deposition velocities by a multiple-resistance approach with aerodynamic, quasilaminar layer and bulk surface resistances acting in series (Wesely, 1989; Zhang et al., 2002). The surface resistance for each compound is obtained by parametric functions of an effective Henry's law at neutral $\mathrm{pH}$ and an estimated oxidative reactivity employing a semi-empirical scaling of these physicochemical properties from those for $\mathrm{SO}_{2}$ and $\mathrm{O}_{3}$ (Table 2). Except on the snow/ice-covered surface, dry deposition is assumed to remove $\mathrm{HBr}, \mathrm{HOBr}, \mathrm{BrONO}_{2}$ and $\mathrm{Br}_{2}$ irreversibly from the atmosphere. On the sea ice and snow/icecovered land surfaces, the surface resistance is reduced to zero for $\mathrm{HOBr}, \mathrm{BrONO}_{2}$ and $\mathrm{HBr}$. As a result, their dry de-
Table 2. Effective Henry's law constants $\left(H^{*}\right)$ at neutral $\mathrm{pH}$ and oxidative reactivity parameters $\left(f_{0}\right)$ for calculating the dry deposition velocities of inorganic bromine species except on the snow/ice covered surface.

\begin{tabular}{lcc}
\hline Species & $H^{*}\left[\mathrm{Matm}^{-1}\right]$ & $f_{0}$ \\
\hline $\mathrm{Br}_{2}$ & $8 \times 10^{-1}\left(\mathrm{see}^{\mathrm{a}}\right)$ & 1 \\
$\mathrm{HOBr}$ & $6 \times 10^{3}\left(\mathrm{see}^{\mathrm{b}}\right)$ & 1 \\
$\mathrm{BrONO}_{2}$ & $2 \times 10^{16}\left(\mathrm{see}^{\mathrm{c}}\right)$ & 1 \\
$\mathrm{HBr}$ & $2 \times 10^{16}\left(\mathrm{see}^{\mathrm{d}}\right)$ & 0 \\
\hline
\end{tabular}

\footnotetext{
a Taken from Bartlett and Margerum (1999).

b Taken from Frenzel et al. (1998).

c Assumed to be the same as the value for $\mathrm{HBr}$.

d Calculated based on Brimblecombe and Clegg $(1988,1989)$ and Lax $(1969)$.
}

position velocities are controlled mainly by the aerodynamic resistance and can be as large as about $1 \mathrm{~cm} \mathrm{~s}^{-1}$ when windy but otherwise orders of magnitude smaller in the statically stable Arctic boundary layer. In addition to the dry deposition, $\mathrm{HBr}$ is assumed to undergo a wet deposition via impaction scavenging in precipitation at a first-order rate constant $\left(3.89 \times 10^{-4} \mathrm{~s}^{-1}\right.$ per $\mathrm{mm} \mathrm{h}^{-1}$ of precipitation) as employed in GEM-AQ for $\mathrm{HNO}_{3}$ (Langner et al., 1998).

The dry deposition of $\mathrm{Br}_{2}$ is assumed not to occur on the snow/ice covered surface; instead, $\mathrm{Br}_{2}$ is emitted to the atmosphere at a rate prescribed from the dry deposition fluxes of $\mathrm{HOBr}, \mathrm{BrONO}_{2}, \mathrm{HBr}$ and $\mathrm{O}_{3}$ (Fig. 1). This approach is similar to the one employed by Lehrer et al. (2004) in their one-dimensional model study. The capacity of the $\mathrm{Br}_{2}$ emission is assumed to vary between the FY and MY sea-ice surfaces and the snow-covered land surface as described below. At first, following the Simpson et al. (2007a) study, we assume that the FY sea ice is more efficient at releasing reactive bromine from its overlying snowpack than the MY sea ice. To evaluate this assumption, however, we conduct another set of model runs in which the reactive bromine release on the MY sea ice is assumed to be as efficient as on the FY sea ice.

The snowpack on the FY sea ice is assumed to retain an inexhaustible storage of $\mathrm{Br}^{-}$so that the total dry deposition flux of $\mathrm{HOBr}$ and $\mathrm{BrONO}_{2}$ is fully converted to the flux of $\mathrm{Br}_{2}$ back to the atmosphere regardless of concurrent $\mathrm{HBr}$ deposition. Thus, as long as chemistry in the near-surface air favors the photochemical formation of $\mathrm{HOBr}$ and $\mathrm{BrONO}_{2}$ over that of $\mathrm{HBr}$, the atmospheric loading of bromine increases autocatalytically via the "bromine explosion".

On the MY sea ice, the supply of $\mathrm{Br}^{-}$is assumed to be limited by the dry deposition of $\mathrm{HBr}$ from the atmosphere, owing to a substantial salinity decrease during summer melt(s) in previous year(s) (Eicken et al., 2002). Also, the formation of open and refreezing leads as a fresh source of sea salt and/or brine is less likely to occur than in the FY sea ice that is more vulnerable to a tensile force arising from 


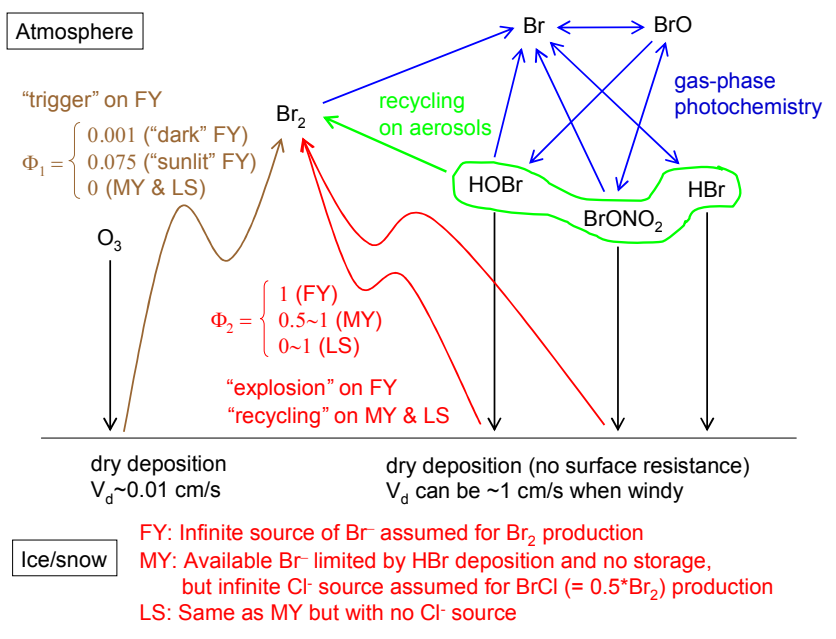

Fig. 1. A schematic of the basic scenario for bromine chemistry in the atmosphere and air-ice/snow interactions of reactive bromine species in the present simulations. FY, MY and LS denote the snowpack on the FY sea ice, the MY sea ice and the land surface, respectively. Presented values for the molar yields $\left(\Phi_{1}\right.$ and $\left.\Phi_{2}\right)$ of $\mathrm{Br}_{2}$ from the dry deposition of $\mathrm{O}_{3}, \mathrm{HOBr}$ and $\mathrm{BrONO}_{2}$ are valid for the model runs $3-5$, whereas the values are somewhat different for other model runs (see Table 3).

surface wind drag and so forth (Richter-Menge and Jones, 1993; Sammonds et al., 1998; Kwok, 2006). The total dry deposition flux of $\mathrm{HOBr}$ and $\mathrm{BrONO}_{2}$, if it is not more than the concurrent deposition flux of $\mathrm{HBr}$, is fully converted to the $\mathrm{Br}_{2}$ emission flux. However, if the deposition flux of $\mathrm{HOBr}$ and $\mathrm{BrONO}_{2}$ exceeds that of $\mathrm{HBr}$, the excess deposition of $\mathrm{HOBr}$ and $\mathrm{BrONO}_{2}$ is converted to $\mathrm{Br}_{2}$ at the $50 \%$ molar yield assuming that $\mathrm{BrCl}$ is released instead of $\mathrm{Br}_{2}$ to the atmosphere by consuming virtually inexhaustible $\mathrm{Cl}^{-}$in the snowpack (e.g., Simpson et al., 2005). This formulation allows for the recycling of up to $100 \%$ of the atmospheric bromine reservoirs entering the snow/ice surface back into the atmosphere instantaneously as $\mathrm{Br}_{2}$. But, in reality, the process would be more complex in that an unused portion of $\mathrm{Br}^{-}$deposited on the snow would likely have a finite residence time and be emitted later as $\mathrm{Br}_{2}$. This is not pursued in the present study. We will show, however, that the scenario described above tends to work somewhat better in simulating the "BrO clouds" across the Arctic than assuming the same efficiency for the release of $\mathrm{Br}_{2}$ from both the FY and MY sea ice sustained equally by an inexhaustible storage of $\mathrm{Br}^{-}$ in the snowpack (Runs 3-5 versus Runs 6-8, see Table 3).

The snow-covered land surface is also assumed to emit $\mathrm{Br}_{2}$ back into the atmosphere but with less efficiency than the snowpack on the MY sea ice. In addition, the terrestrial snowpack is assumed to store no $\mathrm{Cl}^{-}$and $\mathrm{Br}^{-}$so that the $\mathrm{Br}_{2}$ emission flux is determined by taking a smaller flux from either the dry deposition of $\mathrm{HBr}$ or the total dry deposition of $\mathrm{HOBr}$ and $\mathrm{BrONO}_{2}$. Consequently, the recycled fraction of bromine can vary from $\sim 0 \%$ to $100 \%$. As before for the MY sea ice, this overly simplified assumption ignores the observed presence of $\mathrm{Cl}^{-}$and $\mathrm{Br}^{-}$in the terrestrial snowpack as well as the measurements of $\mathrm{BrCl}$ in ambient surface air near the Arctic Ocean (e.g., Foster et al., 2001; Simpson et al., 2005). At a horizontal scale of our model grid $(\approx 100 \mathrm{~km} \times 100 \mathrm{~km})$, however, it is not very unreasonable to assume the absence of $\mathrm{Cl}^{-}$for halogen re-activation in the snowpack over land, since more than two orders of magnitude decrease in the snowpack $\mathrm{Cl}^{-}$concentration has been observed within $150 \mathrm{~km}$ from the coastline in Alaska (Douglas and Sturm, 2004). Also, the snowpack measurements of $\mathrm{Br}^{-}$by Simpson et al. (2005) imply that the air-snow exchange of bromine diminishes towards inland by an order of magnitude or more within a few hundreds kilometers from the coast of the Arctic Ocean. At the timescale of our interest (perhaps longer than 2-3 days) for bromine release from the snow and subsequent ODEs, a boundary-layer air mass would travel farther than that distance in many cases (e.g., Bottenheim and Chan, 2006).

Bromine explosion and recycling processes cannot be initiated without a trigger. For this, more than a few mechanisms have been proposed, including the photolysis of $\mathrm{CHBr}_{3}$ of biogenic origin (Tang and McConnell, 1996), the reactive uptake of ozone onto the $\mathrm{Br}^{-}$-containing ice surface to release $\mathrm{Br}_{2}$ (Oum et al., 1998) and the oxidation of $\mathrm{Br}^{-}$by aqueous-phase $\mathrm{OH}$ radicals and other radical chain reaction products in the brine (Mozurkewich, 1995). Since there are too many unknowns to simulate these processes across the Arctic in a three-dimensional model, we choose to parameterize the trigger simply by associating the loss of ozone via dry deposition to the snow/ice surface with the $\mathrm{Br}_{2}$ emission back into the atmosphere. In this study, the surface resistance of ozone to the snow/ice surface is increased to $10^{4} \mathrm{~s} \mathrm{~m}^{-1}$ (Helmig et al., 2007b) and thus its dry deposition velocity on the snowpack remains close to $0.01 \mathrm{~cm} \mathrm{~s}^{-1}$ under a variety of atmospheric conditions. In Runs $2-5$ the trigger is placed on the FY sea ice only, whereas in Runs 6-8 the trigger is placed on the MY sea ice as well (Table 3). The trigger strength is assumed to be enhanced under sunlight. This is represented by changing the molar yield $\left(\Phi_{1}\right)$ of $\mathrm{Br}_{2}$ against the ozone loss via dry deposition with the solar zenith angle (SZA).

One of the simulation scenarios assumes that the dry deposition flux of ozone is converted to the $\mathrm{Br}_{2}$ emission flux at $\Phi_{1}=10^{-3}$ regardless of SZA on the FY sea ice (Run 2, see Table 3). This is to represent the $\mathrm{Br}_{2}$ formation via reactive uptake of ozone onto frozen seawater in the dark (Oum et al., 1998; Wren et al., 2010). Theoretically, this leads to a build up of $\mathrm{Br}_{2}$ at about $4 \mathrm{pmol} \mathrm{mol}^{-1}$, which is within the measured range in the Arctic surface air during the polar night (Foster et al., 2001), in the $400 \mathrm{~m}$ deep boundary layer solely as a result of dry deposition of ozone at $40 \mathrm{nmol} \mathrm{mol}^{-1}$ over 5 days. It turns out, however, that $\Phi_{1}$ must be much larger for our model to simulate ODEs realistically as observed at stations in the high Arctic (see Sect. 3.1). We find 

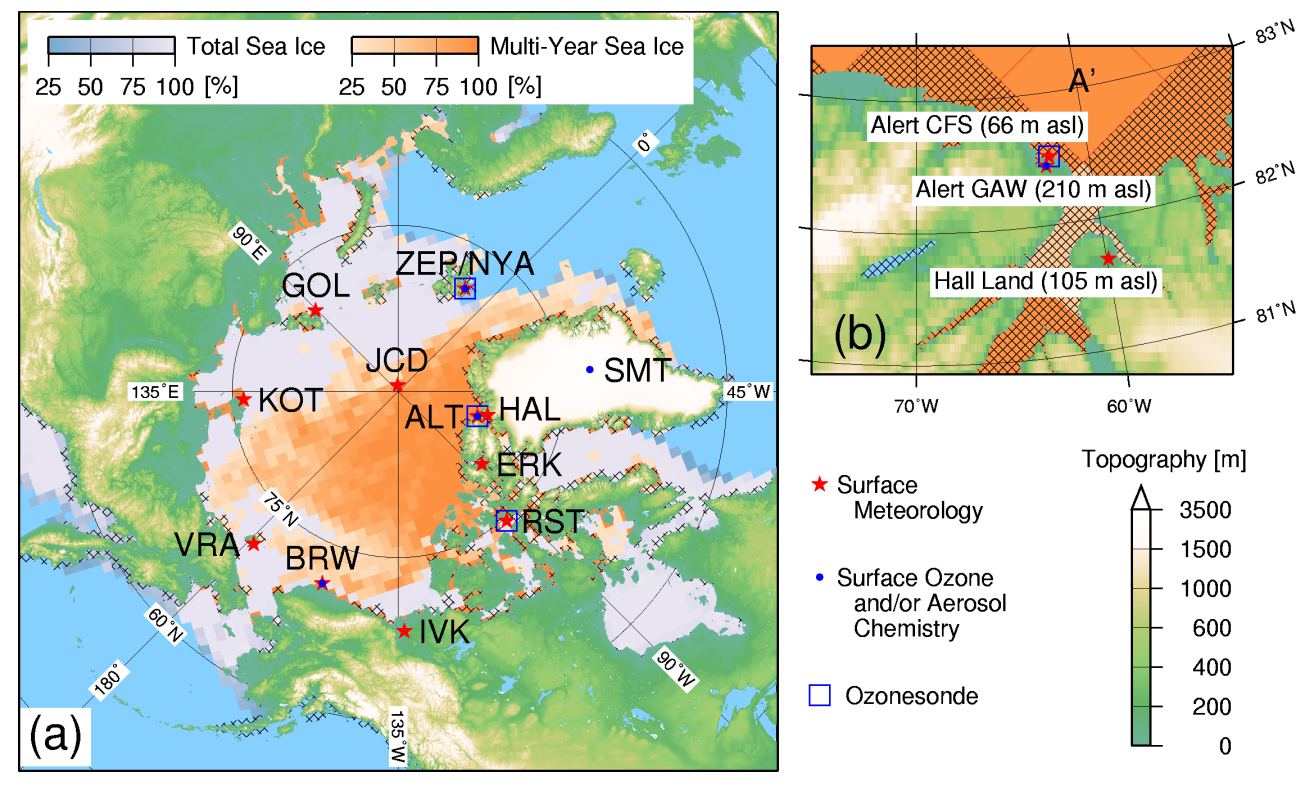

Fig. 2. (a) A circumpolar map showing the location of observation sites for surface meteorology (red stars), surface ozone and aerosol chemistry (blue dots) and ozonesonde sounding (blue open squares) used for evaluating the model simulations. ALT: the Canadian Forces Station (CFS) and the Global Atmosphere Watch (GAW) station at Alert, Ellesmere Island, Canada (66 and $210 \mathrm{~m}$ a.s.1., respectively); BRW: Barrow NOAA/ESRL Observatory, Alaska, USA (8 m a.s.1.); ERK: Eureka, Ellesmere Island, Canada (10 m a.s.1.); GOL: Ostrov Golomjannyj, Russia (8 m a.s.l.); HAL: Hall Land, Greenland (105 m a.s.1.); IVK: Inuvik, Canada (68 m a.s.1.); JCD: J-CAD 3 drifting buoy deployed near the North Pole; KOT: Ostrov Kotelnyj, Russia (8 m a.s.l.); NYA: Ny Ålesund, Svalbard, Norway (18 m a.s.1.); RST: Resolute, Cornwallis Island, Canada (67 m a.s.1.); SMT: Summit, Greenland (3238 m a.s.1.); VRA: Ostrov Vrangelja, Russia (5 ma.s.1.); and ZEP: Zeppelin, Svalbard, Norway (474 m a.s.1.). Also shown are the areas of higher than the $25 \%$ sea-ice concentration from the CMC analyses (light purple shading) overlaid with the areas of higher than the $25 \%$ multiyear sea-ice concentration from the QuikSCAT data (orange shading) for 15 April 2001. Both of the sea ice data are regridded to the horizontal resolution of the model. In the cross-hatched grid cells, snowpack on the sea ice is assumed to act in the same manner as the terrestrial snowpack for the air-ice/snow interactions of bromine in the model because the grid-mean terrain height exceeds $50 \mathrm{~m}$ a.s.l. (see text); (b) A regional map focusing on the area around the Alert CFS and GAW sites in Ellesmere Island, Canada and Hall Land in Greenland. For evaluating simulated ozone mixing ratios at Alert, we also use the model output at the grid cell $\mathrm{A}^{\prime}$ adjacent to the nearest grid cell for the Alert CFS and GAW sites.

that boundary-layer ODEs and $\mathrm{BrO}$ columns can be simulated quite reasonably by increasing $\Phi_{1}$ to $0.05 \sim 0.1$ under sunlight. Hence $\Phi_{1}=0.075$ is assumed for $\mathrm{SZA} \leq 85^{\circ}$ as our baseline (Runs 3-8, see Table 3). We will discuss implications of this fitted value later.

To map the concentrations of MY sea ice on a daily basis for the model, we use a retrieval from the QuikSCAT satellite by scatterometer signals at $13.4 \mathrm{GHz}\left(K_{u}\right.$ band) (Kwok, 2004). The FY sea ice concentrations are calculated by subtracting the MY sea ice concentrations from the total (sea, inland-water and glacier) ice concentrations available daily as part of a global data assimilation at Canadian Meteorological Centre (CMC) (Gauthier et al., 1999) with ice fractions for inland-water and glacier excluded by using land-use category data (Fig. 2). CMC's sea ice analyses are largely based on the Special Sensor Microwave/Imager (SSM/I) satellite data (Steffen et al., 1992). If grid-mean terrain height exceeds $50 \mathrm{~m}$ (hatched areas in Fig. 2), the fractional coverage of sea ice in a grid cell is ignored and the snowpack is assumed to exist exclusively over land to avoid an unrealistic upward migration of reactive bromine in the stably stratified atmosphere.

As mentioned in the introduction, low temperature conditions are believed to be associated somehow with reactive halogen release in the polar boundary layer. In their observational study, Pöhler et al. (2010) concluded that snowpack in the Amundsen Gulf (in the Canadian Arctic) released reactive bromine to the atmosphere when surface air temperature was below $-15{ }^{\circ} \mathrm{C}$ and the rate of bromine release increased linearly with decreasing temperature down to $-24^{\circ} \mathrm{C}$. Based on this, we allow the release of $\mathrm{Br}_{2}$ from the snowpack only where surface air temperature is at and below arbitrarily chosen "critical temperature" $\left(T_{\mathrm{c}}\right)$. We then vary $T_{\mathrm{c}}$ between $-10^{\circ} \mathrm{C}$ and $-20^{\circ} \mathrm{C}$ to study a sensitivity of simulated results on its choice (see Table 3). The snowpack is assumed not to release $\mathrm{Br}_{2}$ but simply to act as a sink for atmospheric bromine where the surface air temperature is above $T_{\mathrm{c}}$. At present, the retrieval of MY sea ice from the QuikSCAT becomes unreliable at surface air temperatures above $-10^{\circ} \mathrm{C}$ due to unmodeled changes in snow and ice properties (Kwok 
Table 3. Description of model runs: "critical temperature" $\left(T_{\mathrm{c}}\right)$ at and below which the snowpack acquires a capability of releasing $\mathrm{Br}_{2}(2 \mathrm{nd}$ column), the type of underlying sea ice where the trigger involving $\mathrm{O}_{3}$ and the bromine explosion involving $\mathrm{HOBr}$ and $\mathrm{BrONO}_{2}$ are assumed to occur (3rd column), and the molar yield $\left(\Phi_{1}\right)$ of $\mathrm{Br}_{2}$ against the loss of $\mathrm{O}_{3}$ via dry deposition for the semi-empirical trigger (4th column).

\begin{tabular}{llll}
\hline Run \# & $T_{\mathrm{c}}$ & Trigger and bromine explosion & $\Phi_{1}$ \\
\hline 1 & \multicolumn{1}{l}{ No bromine release from the snowpack, viz. no bromine chemistry in the atmosphere } \\
2 & $-10^{\circ} \mathrm{C}$ & On FY sea ice only & 0.001 regardless of SZA \\
3 & $-10^{\circ} \mathrm{C}$ & On FY sea ice only & 0.001 for $\mathrm{SZA}>85^{\circ}, 0.075$ for $\mathrm{SZA} \leq 85^{\circ}$ \\
4 & $-15^{\circ} \mathrm{C}$ & On FY sea ice only & 0.001 for $\mathrm{SZA}>85^{\circ}, 0.075$ for $\mathrm{SZA} \leq 85^{\circ}$ \\
5 & $-20^{\circ} \mathrm{C}$ & On FY sea ice only & 0.001 for $\mathrm{SZA}>85^{\circ}, 0.075$ for $\mathrm{SZA} \leq 85^{\circ}$ \\
6 & $-10^{\circ} \mathrm{C}$ & On both FY \& MY sea ice & 0.001 for $\mathrm{SZA}>85^{\circ}, 0.075$ for $\mathrm{SZA} \leq 85^{\circ}$ \\
7 & $-15^{\circ} \mathrm{C}$ & On both FY \& MY sea ice & 0.001 for SZA $>85^{\circ}, 0.075$ for $\mathrm{SZA} \leq 85^{\circ}$ \\
8 & $-20^{\circ} \mathrm{C}$ & On both FY \& MY sea ice & 0.001 for SZA $>85^{\circ}, 0.075$ for $\mathrm{SZA} \leq 85^{\circ}$ \\
\hline
\end{tabular}

et al., 1999). Hence we do not explore the sensitivity of our model results on $T_{\mathrm{c}}$ beyond $-10^{\circ} \mathrm{C}$.

Emissions of aldehydes and nitrogen oxides are known to occur prevalently from the photodegradation of impurities in the snowpack (Grannas et al., 2007) and can be of some importance for perturbing reactive halogen chemistry in the Arctic boundary layer (e.g., Piot and von Glasow, 2008). This issue is not pursued in the present study, since spatial and temporal variations are not characterized adequately yet for the emissions of aldehydes and nitrogen oxides from the snowpack across the Arctic. Our preliminary tests showed that releasing $\mathrm{HCHO}$ from all the snow/ice-covered surface in the model at $4 \times 10^{9}$ molecule $\mathrm{cm}^{-2} \mathrm{~s}^{-1}$, as employed by Michalowski et al. (2000) in their box model study, increased surface ozone mixing ratios at Alert and Barrow during ODEs from below $1 \mathrm{nmol} \mathrm{mol}{ }^{-1}$ to above $5 \mathrm{nmol} \mathrm{mol}^{-1}$ in many cases. On the other hand, $\mathrm{NO}_{2}$ emissions from all the snow/ice-covered surface at $4 \times 10^{8}$ molecule $\mathrm{cm}^{-2} \mathrm{~s}^{-1}$ (Michalowski et al., 2000) showed apparently less impacts on our surface ozone simulation.

\subsection{Simulation period and meteorological constraint}

The GEM-AQ simulation is conducted in a series of 24h free forecast segments from 06:00 UTC 15 March 2001 to 06:00 UTC 2 May 2001, for which 6-h trial fields of the CMC global analyses (Gauthier et al., 1999) are used for re-initializing meteorological and surface boundary conditions. Initial chemical and aerosol fields at 06:00 UTC 15 March 2001 are taken from an archive of global GEMAQ simulation performed without bromine chemistry for the years 2001-2005 spun up from January 2000 (Kaminski et al., 2008). Initial mixing ratios of bromine species are set to zero but, as will be seen later, a spin-up period of about 15 days appears long enough for simulating reactive bromine production and ozone depletion in the Arctic boundary layer. Therefore model results are analyzed for the entire April in 2001.

Simulated surface meteorology is evaluated using automated meteorological observations available from across the
Arctic during the simulated period (see Sect. S1 of the Supplement). The model appears to capture synoptic disturbances as observed reasonably well at sites located within relatively smooth topography such as Barrow, whereas local effects are often pronounced and are not resolved well by the model at sites located between steep subgrid-scale mountains such as Alert. In the latter case, the evaluation of simulated tracer concentrations is compromised and short-term variability on the timescale of less than a day becomes rather meaningless.

\section{Results and discussion}

Table 3 summarizes scenarios for model runs discussed in this study. Run 1 is to simulate a reference case without bromine chemistry, whereas Runs $2-8$ are intended to test different scenarios for the surface source of bromine. Simulated results will be evaluated first by using surface ozone and ozonesonde data obtained routinely at several Arctic sites (Fig. 2). We will then look at day-to-day changes in simulated $\mathrm{BrO}$ column densities and compare them with data derived from satellite measurements.

\subsection{Ground-level mixing ratios and vertical profiles of ozone}

We first tuned the molar yield $\left(\Phi_{1}\right)$ of $\mathrm{Br}_{2}$ for a trigger reaction associated with the dry deposition of ozone, which is one of the most critical empirical parameters introduced in our model (see Sect. 2.3). For this, we used hourly data of surface ozone measurements at Alert, Barrow and Zeppelin where the link between springtime ODEs and reactive bromine chemistry has been established by previous field studies (Simpson et al., 2007b). As indicated from statistical metrics (correlation coefficient, $R$; mean bias, MB; and root mean squared error, RMSE) in Table 4, agreement between simulated and observed surface ozone mixing ratios at these three sites improves when simulated with the adjusted $\Phi_{1}$ value $(=0.075)$ as compared to simulations 
(a) Alert (Ellesmere Island, Canada): $82.50^{\circ} \mathrm{N}, 62.30^{\circ} \mathrm{W}, 210 \mathrm{~m}$ a.s.I.
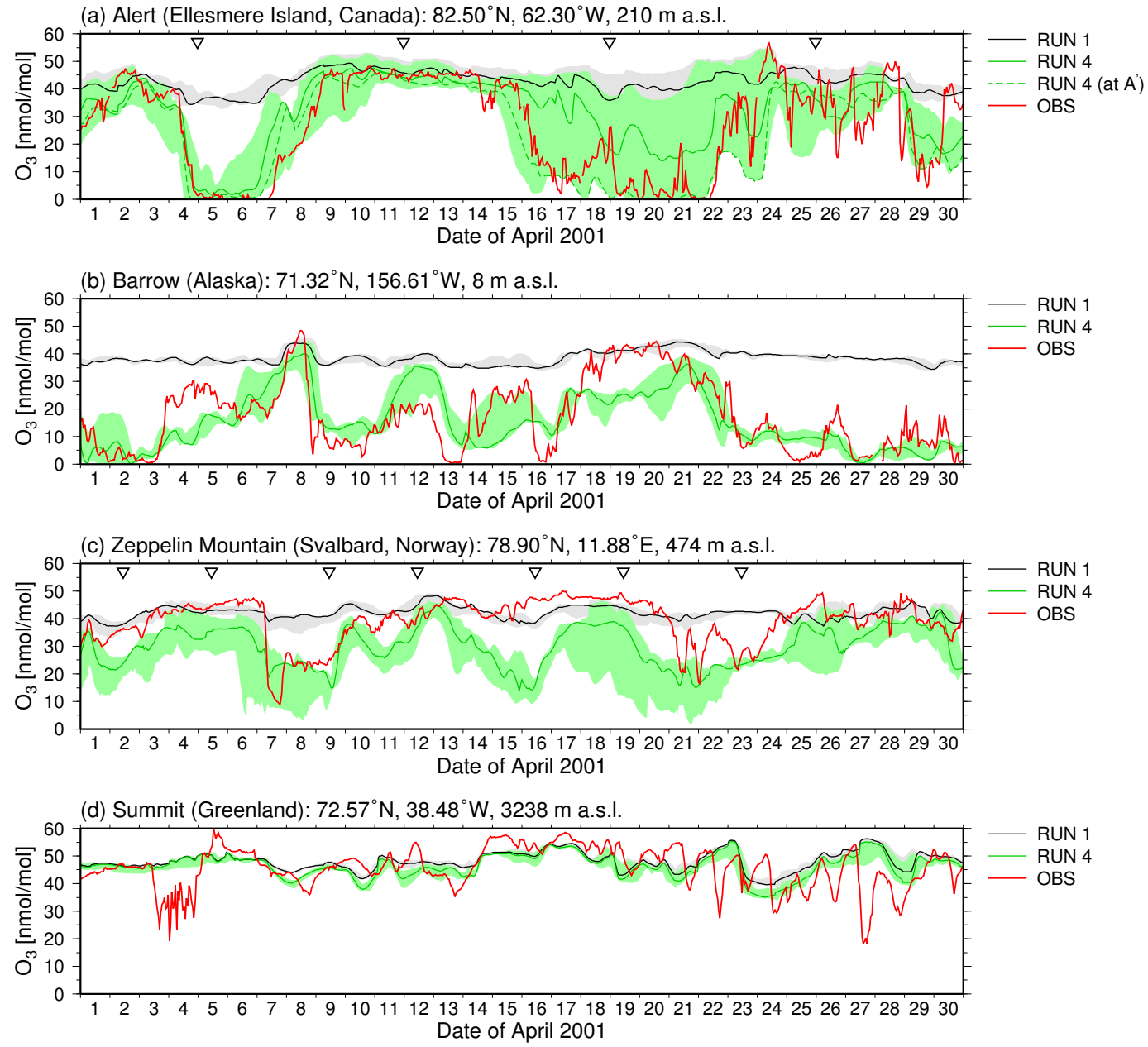

Fig. 3. (a) Comparison of surface ozone mixing ratios simulated in Run 1 (black line) and Run 4 (green lines) with observations at Alert GAW station during April 2001. The solid lines represent simulated time series at the nearest grid cell at the lowest model level, while the range of the simulated values across the nearest and surrounding eight grid cells is indicated by gray and light green shadings (for Run 1 and Run 4, respectively). The red lines, disconnected where missing data points exist, represent hourly observational data. For the simulated time series from Run 4, we also include the values at a neighboring grid cell to the north of Alert (location $\mathrm{A}^{\prime}$ in Fig. 2b) at the third lowest vertical level of the model ( $\sim 170$ m a.s.l.) represented by the green dashed line; (b) the same as (a) but at Barrow; (c) the same as (b) but at Zeppelin, where the simulated values at the nearest and surrounding grid cells are taken from the model vertical levels closest to the station level (474 m a.s.1.); and (d) the same as (b) but at Summit. Inverted triangles in (a) and (c) indicate the launching time of ozonesonde at Alert CFS near the Alert GAW station and at Ny Ålesund near Zeppelin, respectively (see Fig. 4).

without bromine chemistry (Run 1) and with a much smaller $\Phi_{1}$ value (=0.001, Run 2). At Alert and Barrow, the surface ozone mixing ratios simulated in Run 2 are almost the same as simulated in Run 1 and significantly higher than observed particularly during the ODEs. At Zeppelin, the values of MB and RMSE are smaller when simulated without bromine chemistry (Run 1) than with bromine release from the snowpack by using the adjusted $\Phi_{1}$ value (Runs 3-8). However, this is most likely caused by problems other than simulated bromine release as discussed later. Note also that the value of $R$ improves from 0.34 up to 0.58 at Zeppelin by introducing bromine release from the snowpack in the model.
Figure $3 a-c$ shows the time series of surface ozone mixing ratios simulated at Alert, Barrow and Zeppelin, respectively, for Run 1 (without bromine chemistry) and Run 4 (with $T_{\mathrm{c}}=-15^{\circ} \mathrm{C}$ and $\mathrm{FY}$ sea ice is assumed more efficient at bromine release than MY sea ice) plotted along with hourly observational data from corresponding stations. Variations in simulated surface ozone mixing ratios across the nearest and eight neighboring grid cells are also indicated for each simulated time series. The variability is getting especially large at Alert because of inhomogeneous grid-mean terrain heights from 0 to $1215 \mathrm{~m}$ a.s.l. The site elevation of Alert GAW station (Fig. 2b), at which the surface ozone data were obtained, is $210 \mathrm{~m}$ a.s.1., whereas the grid-mean terrain height 
(a) Alert (Ellesmere Island, Canada)
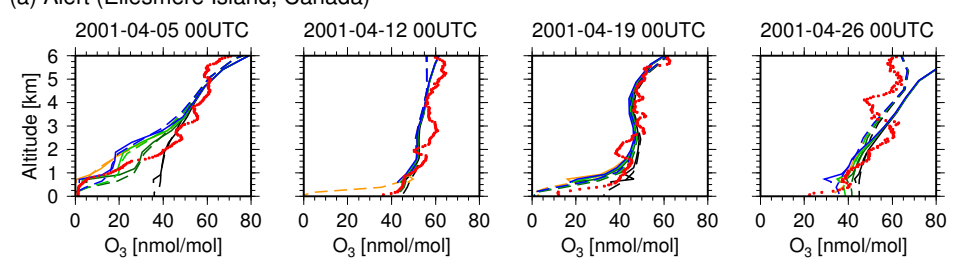

(b) Resolute (Cornwallis Island, Canada)
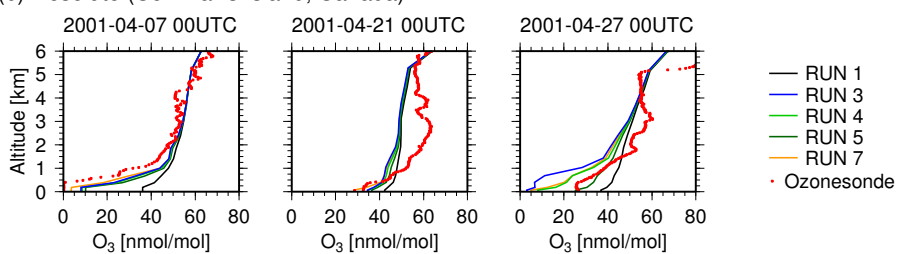

(c) Ny Ålesund (Svalbard, Norway)
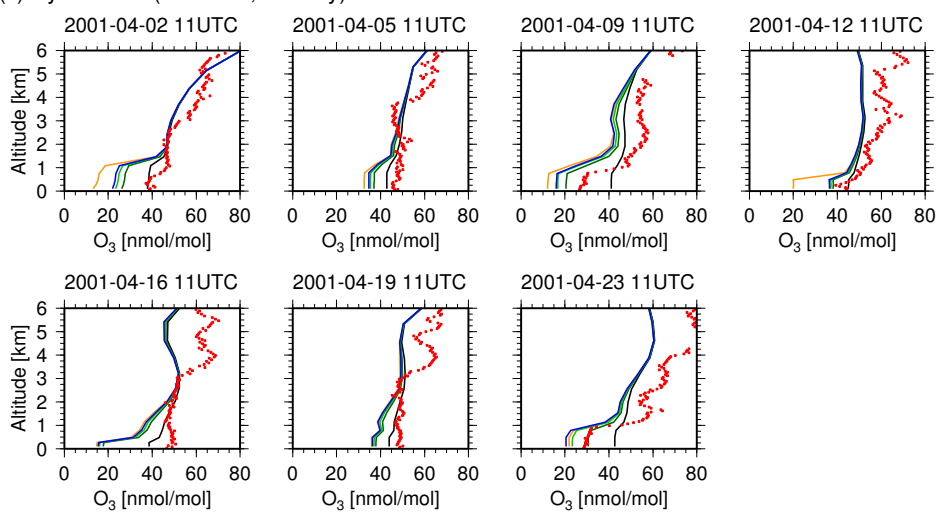

Fig. 4. (a) Comparison of simulated ozone profiles between 0-6 kma.s.l. for Run 1 (black lines), Run 3 (blue lines), Run 4 (light green lines), Run 5 (dark green lines) and Run 7 (orange lines) with observed profiles by ozonesonde (red dots) at Alert CFS. Solid lines are the simulated ozone mixing ratios at the nearest grid cell (with a grid-mean terrain height of $565 \mathrm{~m}$ a.s.l.) whereas dashed lines are those at one of the neighboring grid cells (location $\mathrm{A}^{\prime}$ in Fig. 2b) with a grid-mean terrain height of $0 \mathrm{~m}$ a.s.1.; (b) the same as (a) but at Resolute. Simulated profiles are shown for the nearest grid cell only (solid lines); and (c) the same as (b) but at Ny Ålesund.

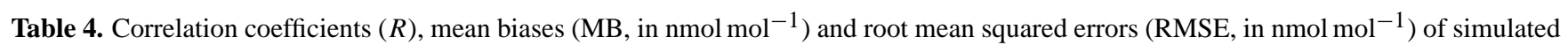
surface ozone mixing ratios against hourly observations at Alert, Barrow, Zeppelin and Summit for all the model runs. The simulated values are taken from the lowest model level, except for Zeppelin where the fourth vertical model level ( $\sim 70 \mathrm{~m}$ a.s.1.) is chosen to match the altitude of the station. The nearest grid cell for Alert has a grid-mean terrain height of $565 \mathrm{~m}$ a.s.1., which is significantly higher than the actual height of surface ozone measurements ( $210 \mathrm{~m}$ a.s.1.); therefore, the statistical metrics are also presented for the third lowest vertical level ( 170 m a.s.l.) at one of the neighboring grid cells (location $\mathrm{A}^{\prime}$ in Fig.2b).

\begin{tabular}{|c|c|c|c|c|c|c|c|c|c|c|c|c|c|c|c|}
\hline \multirow[b]{3}{*}{ Run \# } & \multicolumn{6}{|c|}{ Alert } & \multicolumn{3}{|c|}{ Barrow } & \multicolumn{3}{|c|}{ Zeppelin } & \multicolumn{3}{|c|}{ Summit } \\
\hline & \multicolumn{3}{|c|}{ Nearest Grid Cell } & \multicolumn{3}{|c|}{ Location $\mathrm{A}^{\prime}$} & \multicolumn{3}{|c|}{ Nearest Grid Cell } & \multicolumn{3}{|c|}{ Nearest Grid Cell } & \multicolumn{3}{|c|}{ Nearest Grid Cell } \\
\hline & $R$ & MB & RMSE & $R$ & MB & RMSE & $R$ & MB & RMSE & $R$ & MB & RMSE & $R$ & MB & RMSE \\
\hline 1 & 0.66 & +16.0 & 21.8 & 0.78 & +13.7 & 19.5 & 0.56 & +21.0 & 24.0 & 0.34 & +3.0 & 8.2 & 0.22 & +2.4 & 7.9 \\
\hline 2 & 0.68 & +15.4 & 21.2 & 0.77 & +12.9 & 18.7 & 0.62 & +19.6 & 22.5 & 0.35 & +2.3 & 7.9 & 0.23 & +2.3 & 7.8 \\
\hline 3 & 0.78 & +3.5 & 11.1 & 0.85 & -3.9 & 10.0 & 0.66 & -6.3 & 11.5 & 0.58 & -10.5 & 12.7 & 0.27 & +0.1 & 7.7 \\
\hline 4 & 0.79 & +4.9 & 11.6 & 0.86 & -2.8 & 9.3 & 0.68 & -1.8 & 9.6 & 0.55 & -9.1 & 11.7 & 0.26 & +0.8 & 7.6 \\
\hline 5 & 0.76 & +7.5 & 13.5 & 0.86 & +0.1 & 8.9 & 0.57 & +5.1 & 11.9 & 0.45 & -6.4 & 9.9 & 0.25 & +1.3 & 7.7 \\
\hline 6 & 0.75 & -0.3 & 11.3 & 0.55 & -14.0 & 20.6 & 0.67 & -9.0 & 13.0 & 0.55 & -14.0 & 16.0 & 0.27 & -0.2 & 7.7 \\
\hline 7 & 0.74 & +0.7 & 11.4 & 0.46 & -14.7 & 22.1 & 0.64 & -4.9 & 11.1 & 0.50 & -13.0 & 15.5 & 0.26 & +0.5 & 7.6 \\
\hline 8 & 0.73 & +2.4 & 11.8 & 0.46 & -13.8 & 21.7 & 0.53 & +1.2 & 11.3 & 0.41 & -10.6 & 13.8 & 0.25 & +1.1 & 7.7 \\
\hline
\end{tabular}


is $565 \mathrm{~m}$ a.s.l. at the nearest grid cell of the model. Such a difference in height can be an important source of discrepancy between simulated and observed ozone mixing ratios in the stably stratified boundary layer prevailing in the high Arctic. The vertical extent of boundary-layer ODEs has been observed to vary between episodes from less than $100 \mathrm{~m}$ to as thick as $2000 \mathrm{~m}$ at and around Alert (Anlauf et al., 1994; Hopper et al., 1998; Bottenheim et al., 2002). Since one of the neighboring grid cells (location $\mathrm{A}^{\prime}$ in Fig. 2b) does not contain mountains (but is located entirely on the ocean covered mostly with MY sea ice), simulated ozone mixing ratios at the third lowest vertical level $(\sim 170 \mathrm{~m}$ a.s.l.) from this neighboring grid cell are examined closely as well as at the lowest vertical level from the nearest grid cell. For the same reason, we look at simulated ozone mixing ratios for the nearest grid cell at the fourth lowest vertical level when compared with surface ozone data obtained at Zeppelin located on the crest of a mountain ( $474 \mathrm{~m}$ a.s.1.) unresolved by our model grid. Correlation coefficients between simulated and observed hourly ozone mixing ratios at Alert $(R=0.79$ at the nearest grid cell and $R=0.86$ at location $\left.\mathrm{A}^{\prime}\right)$, Barrow $(R=0.68)$ and Zeppelin $(R=0.55)$ are satisfactorily high for Run 4 with a general improvement from Run 1 (Table 4). Combined with much improved MB and RMSE values for Alert and Barrow, this result indicates that the model is quite reasonably simulating the location and timing of reactive bromine release from the surface snowpack and subsequent ozone loss across the Arctic during the simulated period.

Ozonesonde data from across the Arctic provide additional insights into our simulations. In Fig. $4 \mathrm{a}-\mathrm{c}$, we compare observed and simulated ozone profiles between 0-6 km a.s.l. at Alert CFS, Resolute and Ny Ålesund, respectively. Unfortunately, no ozonesonde data were reported for April 2001 from Barrow, where we find the most tractable meteorology, among the coastal stations studied here, being less susceptible to topography (see Sect. S1 of the Supplement) and where the simulated variability in surface ozone levels is reasonable (see above).

At Alert CFS (66 ma.s.1.), located only $6 \mathrm{~km}$ away from the Alert GAW station (see Fig. 2b), two out of the four ozone soundings in April 2001 were obtained during major ODEs lasting longer than 2 days. On 5 April, observed ozone mixing ratios were below $5 \mathrm{nmol} \mathrm{mol}^{-1}$ from the ground up to $684 \mathrm{~m}$ a.s.l. and then gradually increased with altitude to reach $40 \mathrm{nmol} \mathrm{mol}^{-1}$ at $2 \mathrm{~km}$ a.s.l. On 19 April, the vertical extent of the ozone-depleted layer was much smaller, with $12 \mathrm{nmol} \mathrm{mol}^{-1}$ from the ground up to $183 \mathrm{~m}$ a.s.l. and then increased sharply to $36 \mathrm{nmol} \mathrm{mol}^{-1}$ at $519 \mathrm{~m}$ a.s.l. These changes in the observed ozone profiles are simulated quite well when bromine chemistry is included in the model, although the ozone mixing ratios are underpredicted notably between $1-3 \mathrm{~km}$ a.s.l. on 5 April. According to the wind data from the ozonesonde and from the model, air mass origins on 5 April were vastly different between the ground level and above $1 \mathrm{~km}$ a.s.l.; near the ground level the air came mainly from the north while at $1 \mathrm{~km}$ a.s.l. and higher the air came from the south (not shown). As discussed in Sect. 3.2, the model appears to have a tendency to overestimate the release of reactive bromine in Baffin Bay and the narrows between Greenland and Ellesmere Island located to the south of Alert. At Resolute, located about $1100 \mathrm{~km}$ to the southwest of Alert, the observed profile on 7 April showed a near-complete ozone depletion $\left(\mathrm{O}_{3}<1 \mathrm{nmol} \mathrm{mol}^{-1}\right)$ below $400 \mathrm{~m}$ a.s.l. but had increased to $40 \mathrm{nmol} \mathrm{mol}^{-1}$ by $1.2 \mathrm{~km}$ a.s.l. This profile is simulated quite reasonably by the model with bromine chemistry. Other two ozonesonde profiles from Resolute in April 2001 exhibited an indication of minor ODEs with a decrease in boundary-layer ozone mixing ratios towards the ground level. Although ozone profiles in these two cases are not simulated as well in detail as the profile for 7 April, but the model with bromine chemistry does yield decreasing ozone mixing ratios towards the ground level in a more consistent manner than the model without bromine chemistry. Finally, simulated ozone profiles at Ny Ålesund are also in reasonable agreement with observed profiles especially with regard to the vertical extent of boundary-layer air partially depleted in ozone; however, the model often underpredicts ozone mixing ratios not only in the boundary layer but also in the free troposphere.

Changing $T_{\mathrm{c}}$ from $-15^{\circ} \mathrm{C}$ to either $-10^{\circ} \mathrm{C}$ (Run 3) or $-20^{\circ} \mathrm{C}$ (Run 5) does not drastically impact the simulated surface ozone mixing ratios at Alert. However, the impacts are quite significant at Barrow and Zeppelin. Especially at Barrow, all the statistical metrics indicate a better model performance with $T_{\mathrm{c}}=-15^{\circ} \mathrm{C}$ than with other $T_{\mathrm{c}}$ values (Table 4). Figure 5 shows the simulated time series of surface ozone mixing ratios for Runs 3 and 5 along with hourly observational data at Barrow. Run 3, assuming $T_{\mathrm{c}}=-10^{\circ} \mathrm{C}$, captures the observed ODEs nearly as well as Run 4, while resulting in too much ozone depletion during some of the periods when surface ozone at Barrow actually recovered to $30 \mathrm{nmol} \mathrm{mol}^{-1}$ or higher (e.g., 14-15 April, 21-23 April). On the other hand, with $T_{\mathrm{c}}=-20^{\circ} \mathrm{C}$ (Run 5), the model simulates the decrease in surface ozone levels barely as intense as observed at Barrow after early April. These results are consistent with a recent observational study by Pöhler et al. (2010), in which they concluded that reactive bromine was released from the snow/ice surface to the atmosphere most likely at surface air temperatures below $-15^{\circ} \mathrm{C}$ in the Amundsen Gulf.

At Zeppelin, the values of $R$ suggest a better model performance in Runs 3 and $4\left(T_{\mathrm{c}}=-10^{\circ} \mathrm{C}\right.$ or $\left.-15^{\circ} \mathrm{C}\right)$ than in Run $5\left(T_{\mathrm{c}}=-20^{\circ} \mathrm{C}\right)$, but trends in the MB and RMSE values are somewhat contradictory (Table 4). As shown in Fig. 3c, the model underpredicts the ozone mixing ratios almost all the time in Run 4 and simulates a false occurrence of a surface ozone dip during 14-16 April. Nonetheless, two episodes of relatively low ozone mixing ratios between 10 30 $\mathrm{nmol} \mathrm{mol}^{-1}$ during 7-9 April and 21-23 April are 


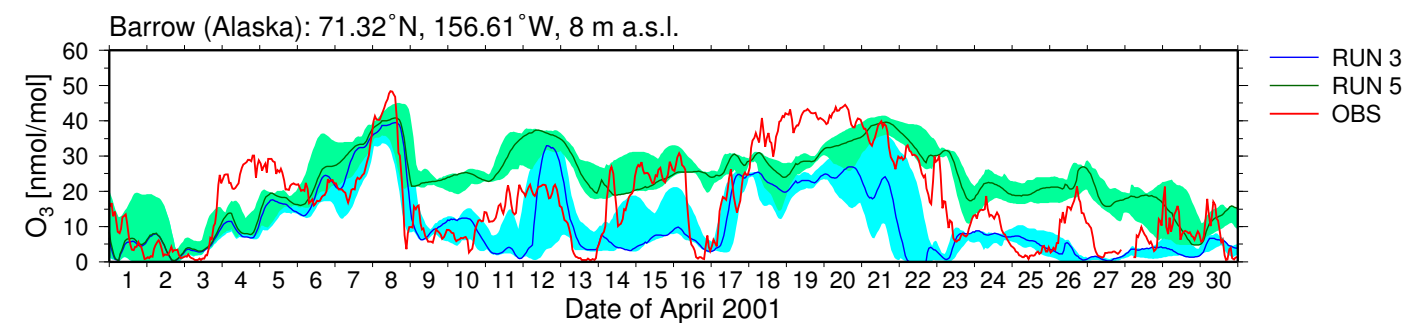

Fig. 5. The same as Fig. $3 b$ but for simulated surface ozone mixing ratios at the nearest and surrounding grid cells to Barrow from Run 3 (blue line and shading) and Run 5 (green line and shading).

(a) RUN 3

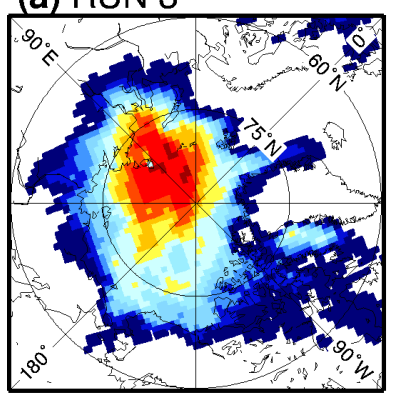

(d) RUN 6

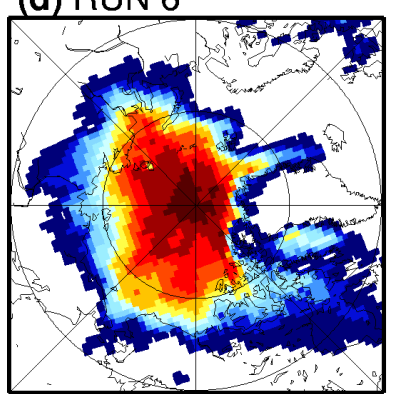

(b) RUN 4

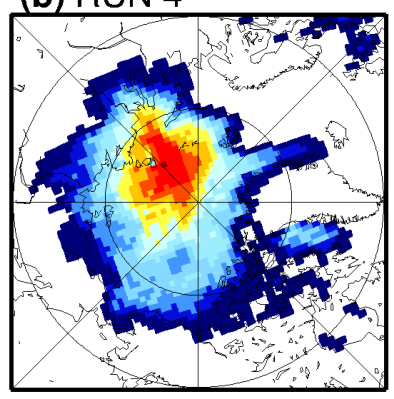

(e) RUN 7

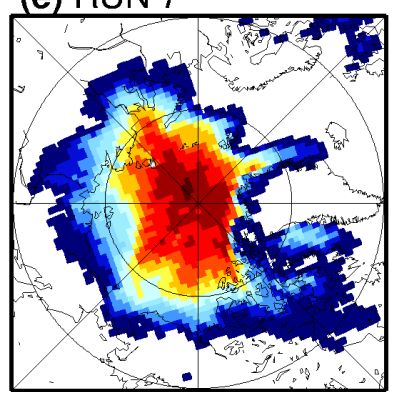

(c) RUN 5

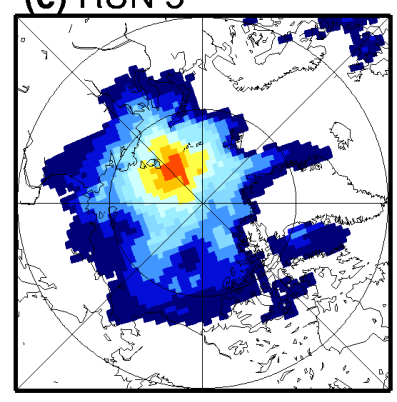

(f) RUN 8

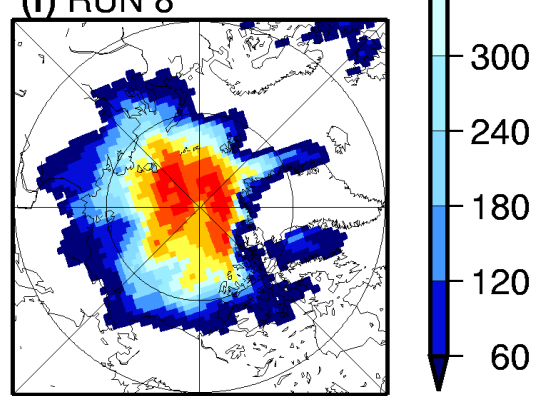

[hours]

A 660

$-600$

$-540$

$-480$

$-420$

$-360$

300

240

80

120

60

Fig. 6. Total hours of simulated episodes with surface ozone mixing ratios below $5 \mathrm{nmol} \mathrm{mol}^{-1}$ at each grid cell during April 2001: (a) Run 3 , (b) Run 4, (c) Run 5, (d) Run 6, (e) Run 7, and (f) Run 8.

reproduced fairly well. As noted before, simulated ozone profiles within and above the boundary layer at Ny Ålesund, located in the same grid cell of the model as Zeppelin, point to a possibility that some of the underpredicted surface ozone mixing ratios at Zeppelin could be attributed to the low bias in background ozone levels simulated by our model (Fig. 4c). In addition, simulated sulfate aerosol concentrations are higher by a factor of 5-10 than daily measurements at Zeppelin (see Sect. S2 of the Supplement). Consequently, the partitioning of inorganic bromine around Zeppelin could be shifted unrealistically towards photolabile and radical species via heterogeneous aerosol reactions even if a source of bromine from the snow/ice surface was simulated reasonably well in the model.

We have started our model runs by assuming that the snowpack is more efficient at releasing reactive bromine on the FY sea ice than on the MY sea ice as indicated by Simp- son et al. (2007a). To evaluate this assumption, sensitivity experiments were performed in which the reactive bromine release occurs on the MY sea ice as efficiently as on the FY sea ice (Runs 6-8, see Table 3). These model runs yielded more persistent ODEs over a vast area on the Canadian/Alaskan side of the Arctic Ocean mainly covered with the MY sea ice (Fig. 6a-f). The changes from Runs 3-5 to Runs 6-8 are so significant that our model scenarios could have been evaluated quite convincingly perhaps if several drifting buoys equipped with a system for continuous surface ozone measurements had been deployed across the Arctic Ocean (e.g., Knepp et al., 2010). This is not the case for April 2001, but we do see substantial changes in the simulated ozone mixing ratios at a neighboring grid cell to the north of Alert (location $\mathrm{A}^{\prime}$, see Fig. 2b). If simply compared with ground-level ozone mixing ratios observed at Alert GAW station (Fig. 7) and with ozonesonde data from Alert CFS (Fig. 4a, particularly 


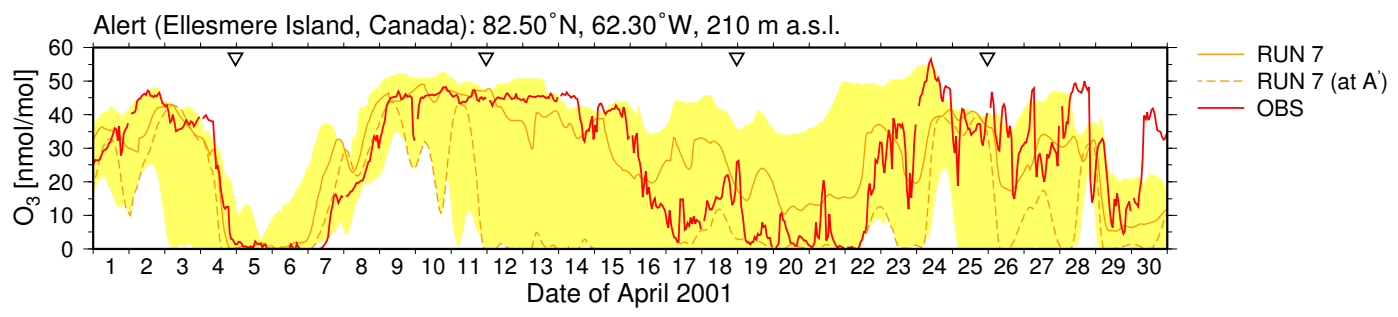

Fig. 7. The same as Fig. 3a but for simulated surface ozone mixing ratios at the nearest and surrounding grid cells to Alert from Run 7 (orange solid/dashed lines and yellow shading).

on 12 April 2001), the near-surface ozone mixing ratios at location $\mathrm{A}^{\prime}$ are significantly underpredicted most of the time in Run 7 and therefore look unsatisfactory as compared to Run 4 (Fig. 3a). The values of $R$ for simulated ozone at location $\mathrm{A}^{\prime}$ are notably reduced for all the $T_{\mathrm{c}}$ ranges tested in Runs 6-8 $(R=0.46 \sim 0.55)$ from Runs 3-5 $(R=0.85 \sim$ $0.86)$ and even lower than that $(R=0.78)$ obtained in Run 1 where bromine chemistry is switched off (Table 4). On the other hand, previous field studies have found that ODEs on ice floes only 5 to $160 \mathrm{~km}$ apart from Alert are obviously more persistent than observed at the coastal stations nearby (Hopper and Hart, 1994; Hopper et al., 1998; Morin et al., 2005). It has also been reported that surface snowpack on the MY sea ice can be substantially enriched in $\mathrm{Br}^{-}$by late March near Alert (Ariya et al., 1999; Toom-Sauntry and Barrie, 2002). This could arise from the airborne transport of gaseous and particulate bromine released from open and/or refrozen leads located nearby or even from the ones located rather distantly if bromine deposited to the snowpack is reemitted to the atmosphere successively (Simpson et al., 2005; Piot and von Glasow, 2008). It is therefore possible that the ozone mixing ratios at location $\mathrm{A}^{\prime}$ are simulated more realistically in Runs 6-8 (i.e., with no distinction between the FY and MY sea ice surfaces for bromine release) than in Runs 35. This, however, cannot be assessed unambiguously owing to a lack of field ozone measurements on ice floes near Alert during the simulated period. Surface ozone and ozonesonde data from other Arctic sites used in this study do not allow us to draw a definitive conclusion about this issue.

We also looked at surface ozone data from Summit, Greenland (3238 ma.s.1.) to evaluate if the simulated ozone levels were significantly biased or not in the Arctic free troposphere, with an expectation of minimal impacts due to reactive bromine released on the sea ice. Summit is located above a typical height range where the impacts of bromine chemistry on ozone profiles are apparent in our model runs at Alert, Resolute and Ny Ålesund (Fig. 4a-c). Indeed, the surface ozone mixing ratios simulated at Summit do not change very much between our model runs. Also, relatively small MB and RMSE values to the observed mixing ratios (Table 4) provide some assurance of model credibility for simulating background ozone levels around the site. The values of
$R$, however, are generally low $(R<0.3)$ in all the model runs because of a poor capability of the model to reproduce a large daytime decrease (sometimes by more than $10 \mathrm{nmol} \mathrm{mol}^{-1}$ ) observed particularly after 20 April 2001 (Fig. 3d). The reason for this discrepancy is not clear. At Summit, Helmig et al. (2002) observed a daytime ozone decrease of similar magnitude occasionally during June 2000. A strong ozone sink in the local snowpack was also indicated from ozone measurements in the interstitial air during another field study at Summit (Helmig et al., 2007a). To reconcile the in-situ measurements of $\mathrm{HO}_{\mathrm{x}}$ radicals at Summit during summer 2003 with a box model simulation, Sjostedt et al. (2007) speculated an involvement of iodine and bromine photochemistry most notably when air mass had been transported from the marine boundary layer (not necessarily over sea ice) with local drifting snow promoting the heterogeneous reactions of halogens. More recent field data covered in-snow bromide and ambient $\mathrm{BrO}$ radical measurements and showed that the bromine photochemistry can be quite active in the interstitial air of the snowpack and in the ambient air above the snow at Summit in the summer, but not to the extent of causing a large daytime decrease in ozone as observed during April 2001 (Dibb et al., 2010; Thomas et al., 2010). On the other hand, Dibb et al. (2007) measured enhanced concentrations of dust mineral components in the surface snowpack at Summit particularly between 23-26 April 2001, originating most likely from Asian dust storms. As has been shown experimentally, certain dust minerals can promote the oxidation of halides into photolabile molecular halogens via heterogeneous surface reactions (Sadanaga et al., 2001; Anastasio and Mozurkewich, 2002).

Finally, it is worth noting results from another version of GEM-AQ by Zhao et al. (2008), which covered the same simulation period as ours. They assumed that frost flowers are abraded by a wind to produce airborne sea-salt particles as a source of reactive halogens in the Arctic boundary layer. The locations of the frost flowers were determined based on the PFF data by Kaleschke et al. (2004). It appears that surface ozone mixing ratios at Alert, Barrow and Zeppelin were depleted much too frequently in the Zhao et al. (2008) model at least during April 2001 (see Fig. 3 in their paper), indicating either that frost flowers are not important as a source 
of reactive bromine or inaccuracy in the PFF algorithm employed by Kaleschke et al. (2004). Alternatively, the source term for wind-blown frost flowers by Zhao et al. (2008) could have been improved simply by scaling it down with some additional constraints presently unknown. By design, the PFF algorithm calculates an upper limit for the occurrence of real frost flowers one could observe in the field.

\subsection{Spatial and temporal evolutions of BrO columns}

Space-borne measurements of $\mathrm{BrO}$ columns provide a useful means of evaluating our simulations particularly over sea ice where reactive bromine is actively released to the atmosphere. Here we use tropospheric $\mathrm{BrO}$ vertical column densities (VCDs) derived from a combination of total $\mathrm{BrO}$ columns measured by the Global Ozone Monitoring Experiment (GOME) instrument and $\mathrm{BrO}$ columns above the tropopause simulated by a stratospheric chemical transport model (Richter, 2006).

GOME is a UV/visible spectrometer on board the ERS2 satellite. Slant column densities (SCDs) of atmospheric trace species are retrieved by applying a differential optical absorption algorithm to the measured spectra of sunlight scattered/reflected back from the earth's atmosphere in nearnadir $\left( \pm 32^{\circ}\right)$ viewing geometry. For $\mathrm{BrO}$, the spectral fitting window in the $345-359 \mathrm{~nm}$ wavelength region measured at $0.2 \mathrm{~nm}$ resolution was used (Richter et al., 2002). The BrO SCDs were then converted to VCDs by using air mass factors (AMFs) for an assumed stratospheric $\mathrm{BrO}$ profile with mixing ratios linearly increasing from 20 to $30 \mathrm{~km}$ and constant above $30 \mathrm{~km}$ (Richter et al., 1998). Data obtained where $\mathrm{SZA}>80^{\circ}$ were discarded because retrieval sensitivity is shifted towards stratospheric $\mathrm{BrO}$ rather than tropospheric $\mathrm{BrO}$. To obtain the tropospheric $\mathrm{BrO}$ columns, stratospheric $\mathrm{BrO}$ SCDs were subtracted from the total BrO SCDs by using output from the SLIMCAT middle-atmosphere chemical transport model (Chipperfield, 1999) at a horizontal resolution of $7.5^{\circ} \times 7.5^{\circ}$. The model was driven by assimilated meteorology to address day-to-day changes in stratospheric dynamics and transport. The tropopause level was defined either by the potential temperature of $380 \mathrm{~K}$ or by the potential vorticity of $2 \mathrm{PVU}$ (potential vorticity unit, $=10^{-6} \mathrm{~K} \mathrm{~m}^{2} \mathrm{~kg}^{-1} \mathrm{~s}^{-1}$ ). The version of SLIMCAT used here had a total inorganic bromine $\left(\mathrm{Br}_{\mathrm{y}}\right)$ loading in the stratosphere at $21 \mathrm{pmol} \mathrm{mol}^{-1}$ with a source gas represented by $\mathrm{CH}_{3} \mathrm{Br}$ only (Chipperfield et al., 2005), which, however, most likely underrepresents $\mathrm{BrO}$ columns in the lowermost stratosphere as discussed later. Daily tropospheric $\mathrm{BrO}$ VCDs thus obtained were gridded at $0.5^{\circ} \times 0.5^{\circ}$. Hereafter, we call this product the GOME-SLIMCAT tropospheric $\mathrm{BrO}$ VCDs.

For the evaluation of simulated $\mathrm{BrO}$ columns, we account for a varying sensitivity of the GOME measurements to altitude where $\mathrm{BrO}$ is actually located, surface reflectivity (albedo) and SZA. As described in Appendix A, the simu- lated $\mathrm{BrO}$ columns are first converted to apparent slant column densities (ASCDs) by applying clear-sky box AMFs and are then divided by geometric AMFs, which approximate the stratospheric AMFs used for the GOME BrO retrieval. This gives what we call the adapted vertical column densities (AVCDs). To synchronize loosely with GOME's overpass in the Arctic region, the model-derived AVCDs are sampled only from $0-1 \mathrm{pm}$ local time slices over $24 \mathrm{~h}$ for daily comparison with the GOME-SLIMCAT tropospheric BrO VCDs.

Figure 8a-d shows the GOME-SLIMCAT tropospheric BrO VCDs and the BrO AVCDs simulated by GEM-AQ in Runs 3-5 for each day between 15-22 April 2001. During this period, "BrO clouds" emerged, evolved to spatial scales of greater than $1000 \mathrm{~km}$, and then diminished at timescales of about 2 to 4 days. Over the eastern and central Arctic Ocean off the coast of Siberia, an arc-shaped "BrO cloud", which appears to have been initiated on 15 April, matured between 16-17 April. Another event took place a few days later in the same area of the Arctic Ocean. A comma-shaped "BrO cloud" that matured on 20 April appears to have been initiated on 19 April near the Siberian coast around $135^{\circ} \mathrm{E}$ and then moved westward to reach Barents Sea on 22 April while being deformed and diminished. The shape of the "BrO clouds" in these two prominent cases are best simulated in Run 3, in which $T_{\mathrm{c}}=-10^{\circ} \mathrm{C}$ is assumed (Fig. 8b). As shown by the surface air temperature and wind fields at 12:00 UTC for each day during the same period (Fig. 9a), these events were characterized by relatively "warm" temperatures sometimes as high as $-10^{\circ} \mathrm{C}$ associated with air mass transport from the south. It also appears that strong boundary-layer winds resulted in a break-up of surface inversions to raise the surface temperatures further. If we assume that bromine release from the snowpack is terminated at surface temperatures above $-15^{\circ} \mathrm{C}$, the model does not yield the source of bromine at the right time and in the right place so that the "BrO clouds" begin to lose a resemblance in their shape as compared to the GOME-SLIMCAT data (Fig. 8c). If $T_{\mathrm{c}}=-20^{\circ} \mathrm{C}$ is assumed, the "BrO clouds" in their maturity on 16-17 April and on 20 April disappear totally in the model (Fig. 8d). On the other side of the Arctic, a region that covers Hudson Bay and a southern part of the Canadian Arctic Archipelago also exhibited a frequent occurrence of " $\mathrm{BrO}$ clouds" during 15-22 April 2001. These events were also characterized by strong surface winds associated with synoptic disturbances, but surface temperatures did not increase so obviously as in the eastern Arctic cases described above because of air mass transport mainly from the north (Fig. 9a). Again, the "BrO clouds" do not emerge as can be seen in the GOME-SLIMCAT data when $T_{\mathrm{c}}=-20^{\circ} \mathrm{C}$ is assumed in the model.

Figure 10a-f shows the scatter plots of GOME-SLIMCAT $\mathrm{BrO}$ VCDs versus $\mathrm{BrO}$ AVCDs simulated in Runs 3-8, respectively, sampled only to the north of $55^{\circ} \mathrm{N}$ and for $\mathrm{SZA} \leq 80^{\circ}$ for the entire April 2001. This confirms that the evolution of "BrO clouds" is best simulated in our 
(a) GOME-SLIMCAT Tropospheric BrO VCD
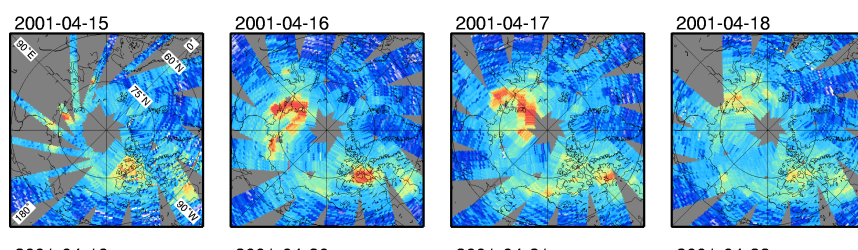

2001-04-19 2001-04-20
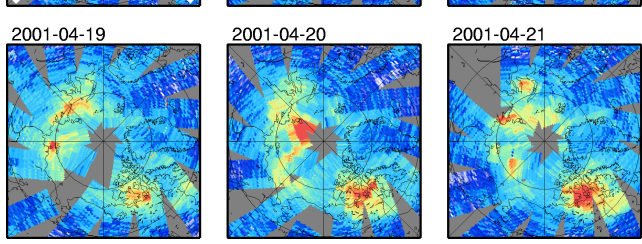

2001-04-22

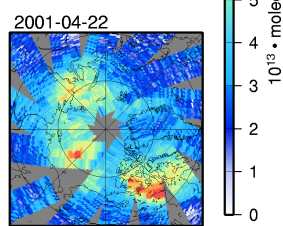

(b) GEM-AQ BrO AVCD (RUN 3: $T_{c}=-10^{\circ} \mathrm{C}$, Net Bromine Release From FY Sea Ice Only)
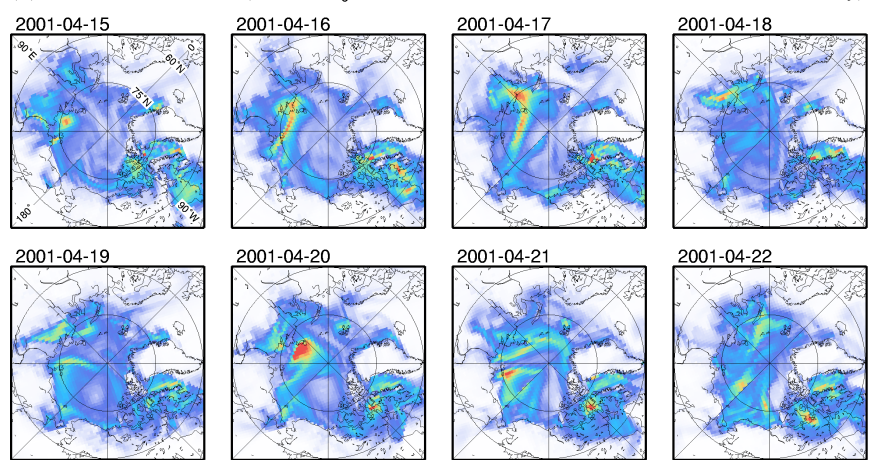

2001-04-22
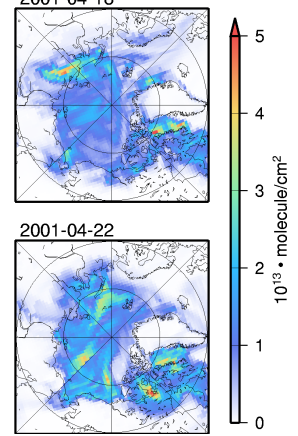

(c) GEM-AQ BrO AVCD (RUN 4: $T_{\mathrm{c}}=-15^{\circ} \mathrm{C}$, Net Bromine Release From FY Sea Ice Only)
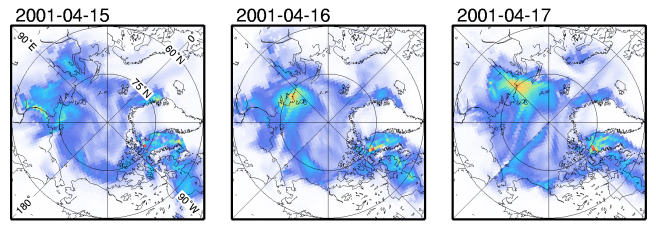

2001-04-19

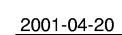

2001-04-21
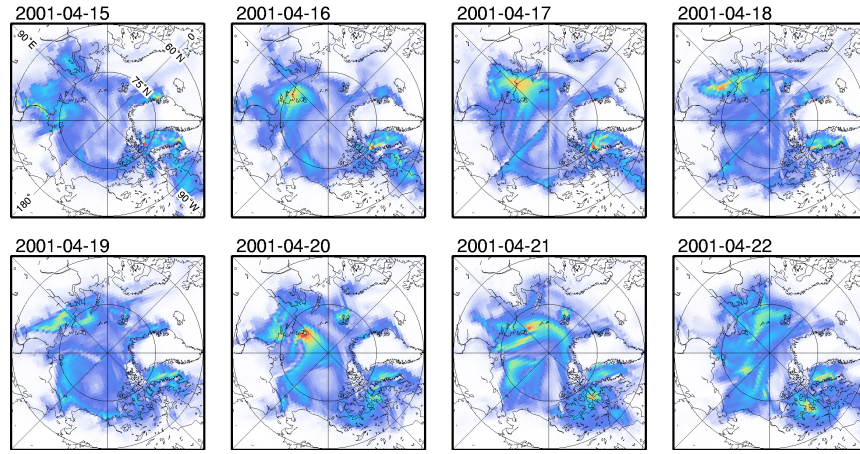

2001-04-22
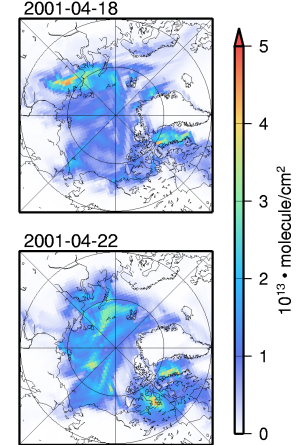

(d) GEM-AQ BrO AVCD (RUN 5: $T_{\mathrm{c}}=-20^{\circ} \mathrm{C}$, Net Bromine Release From FY Sea Ice Only)
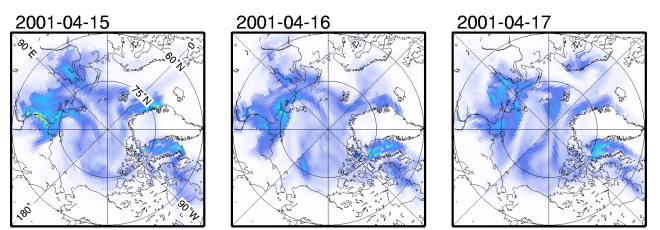

2001-04-19

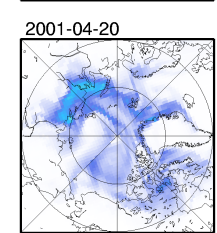

2001-04-21
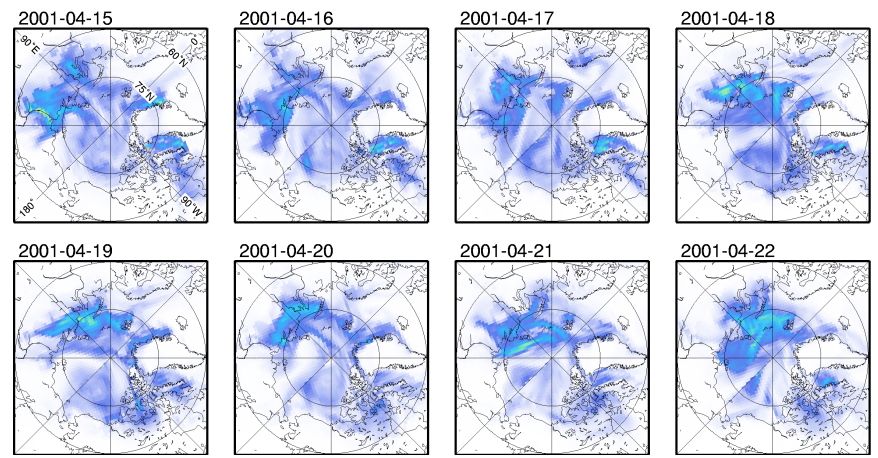

2001-04-22
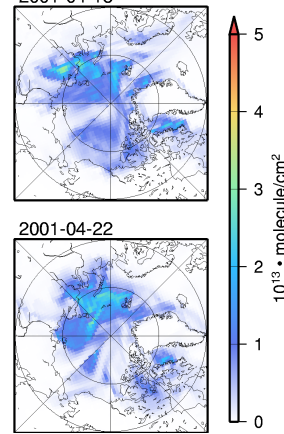

Fig. 8. (a) GOME-SLIMCAT tropospheric BrO VCDs (in molecule $\mathrm{cm}^{-2}$ ) for each day between 15-22 April 2001; (b) The same as (a) but for BrO AVCDs (in molecule $\mathrm{cm}^{-2}$ ) simulated by GEM-AQ in Run 3; (c) The same as (b) but simulated in Run 4; and (d) The same as (b) but simulated in Run 5. Note different color scales used for the GOME-SLIMCAT BrO VCDs and the GEM-AQ BrO AVCDs. 
(a) GEM Surface Meteorology
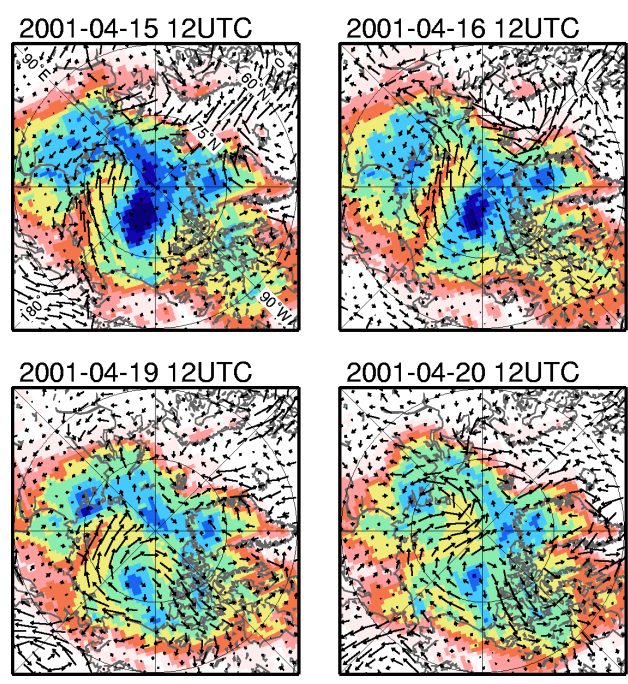

2001-04-20 12UTC

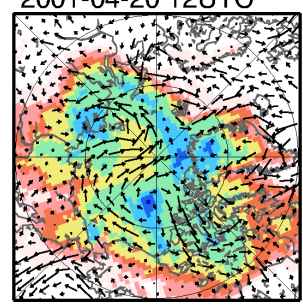

(b) GEM-AQ Surface Ozone (RUN 4)
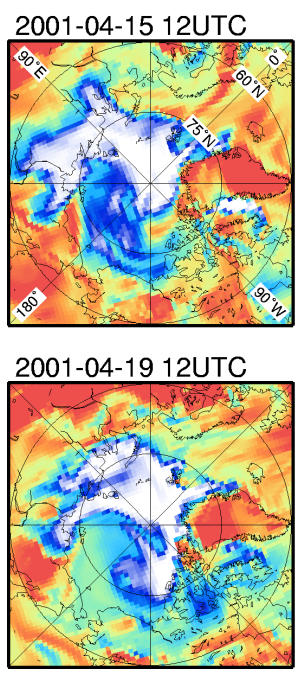
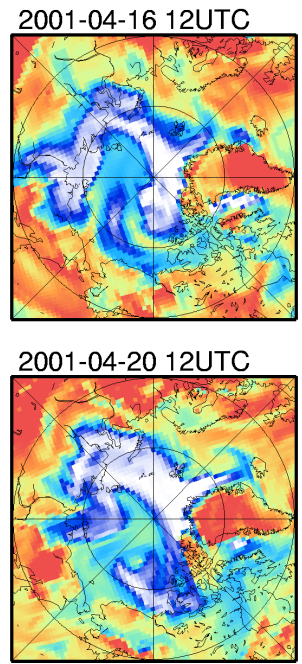
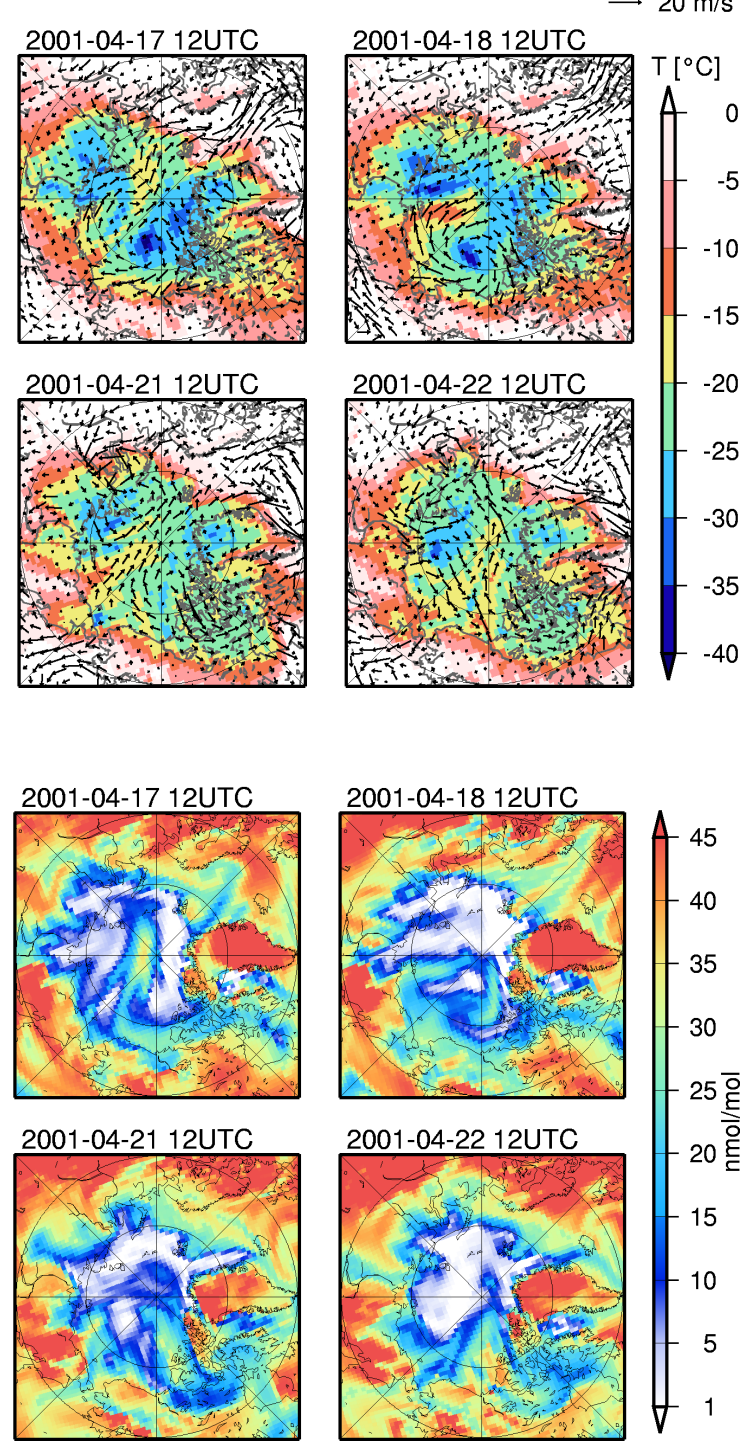
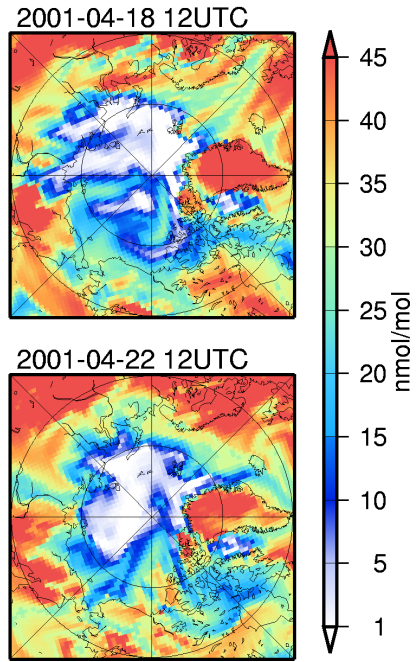

Fig. 9. (a) Surface air temperatures (color shade, in ${ }^{\circ} \mathrm{C}$ ) and wind vectors (arrow length for the wind speed of $20 \mathrm{~m} \mathrm{~s}^{-1}$ is indicated in the top right corner) at 12:00 UTC each day between 15-22 April 2001 simulated by the model; and (b) The same as (a) but for surface ozone mixing ratios (in nmol mol${ }^{-1}$ ) simulated in Run 4 .

model with $T_{\mathrm{c}}=-10^{\circ} \mathrm{C}$, somewhat underrepresented if simulated with $T_{\mathrm{c}}=-15^{\circ} \mathrm{C}$ and significantly undermined with $T_{\mathrm{c}}=-20^{\circ} \mathrm{C}$. Implications of this result will be discussed in Sect. 3.4. Next, agreement between the model and the GOME-SLIMCAT data is modestly better when bromine release is assumed to be more efficient on the FY sea ice than on the MY sea ice for $T_{\mathrm{c}}=-15 \sim-10^{\circ} \mathrm{C}$. As discussed previously when evaluating the boundary-layer ozone simulations, the potential of reactive bromine release to the atmosphere may not be very different in reality between the FY sea ice and the MY sea ice as assumed in Runs 3-5, because bromide would also likely be enriched in the surface snow widely on the MY sea ice (and in the coastal snow surface) in the spring as a result of the airborne transport of bromine involving successive re-emissions across the icecovered ocean from original sources such as refreezing leads (Ariya et al., 1999; Toom-Sauntry and Barrie, 2002; Simpson et al., 2005). Nevertheless, the improvement in the simulated $\mathrm{BrO}$ columns from Runs 6-7 to Runs 3-4 suggests that some advantageous physical and/or chemical mechanisms exist on the FY sea ice for an enhanced bromine release to the atmosphere.

We note that, even in Run 3 which simulates the morphological evolutions of "BrO clouds" most successfully, 
$T_{\mathrm{c}}=-10^{\circ} \mathrm{C}$

(a) RUN 3

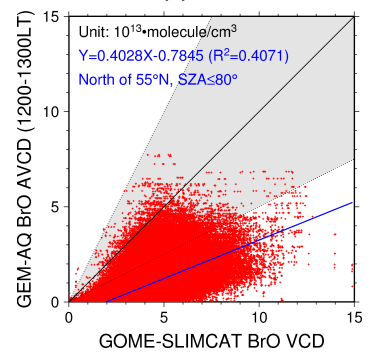

(d) RUN 6

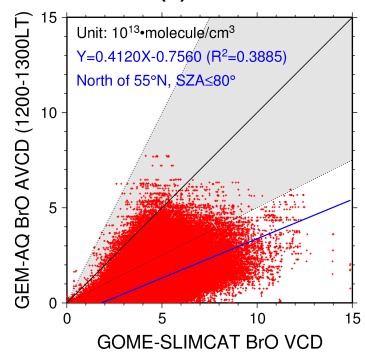

$T_{\mathrm{c}}=-\mathbf{1 5}^{\circ} \mathrm{C}$

(b) RUN 4

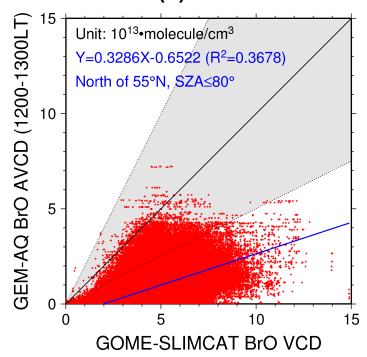

(e) RUN 7

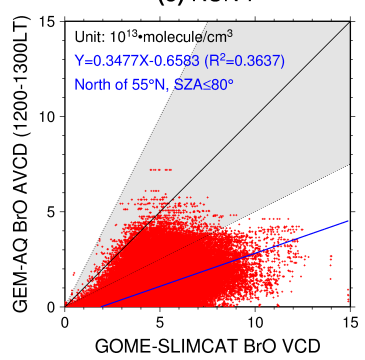

$T_{\mathrm{c}}=-20^{\circ} \mathrm{C}$

(c) RUN 5

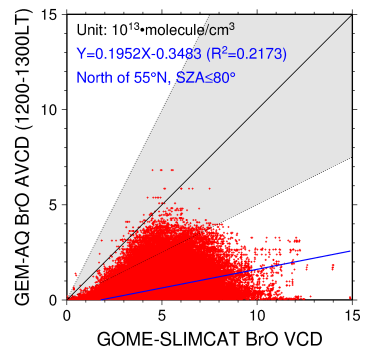

Net Bromine

Release From

FY Sea Ice

Only

Fig. 10. Scatter plots of GEM-AQ BrO AVCDs versus GOME-SLIMCAT tropospheric BrO VCDs to the north of $55^{\circ} \mathrm{N}$ and for $\mathrm{SZA} \leq 80^{\circ}$ during 1-30 April 2001. The GEM-AQ output (at the resolution of $0.88^{\circ} \times 0.88^{\circ}$ in the Arctic core) is regridded to $0.5^{\circ} \times 0.5^{\circ}$ used for the GOME-SLIMCAT dataset: (a) Run 3, (b) Run 4, (c) Run 5, (d) Run 6, (e) Run 7, and (f) Run 8.

the simulated BrO AVCDs are smaller than the GOMESLIMCAT tropospheric BrO VCDs quite often by more than a factor of two. This is puzzling, because we ignore the effect of ice/water cloud cover that can mask the "BrO clouds" underneath. Therefore the BrO AVCDs from the model should be considered as an upper limit when looking at the events of increased bromine concentrations in the boundary layer. Over the bright snow/ice surface, a multiple-scattering of photons between the clouds and the surface would allow space-borne sensors to retain a considerable sensitivity to $\mathrm{BrO}$ below the cloud layer(s) but most likely to a lesser extent than in the clear sky without the clouds (e.g., Vasilkov et al., 2010). Given that the boundary-layer ozone variations are simulated reasonably well across the Arctic (see Sect. 3.1), it is not very useful to force the model results towards higher $\mathrm{BrO}$ concentrations by further adjusting the empirical parameters associated with bromine release from the snowpack. Also, there is an offset between the loss of ozone and the production of $\mathrm{BrO}$ in the boundary layer (e.g., Hausmann and Platt, 1994) so that increasing the rate of reactive bromine release does not necessarily lead to higher $\mathrm{BrO}$ concentrations in the model. We will return to this issue in Sect. 3.3.

Despite the general tendency for $\mathrm{BrO}$ columns in the model simulations to be underpredicted, some regions of the Arctic, including Baffin Bay, often exhibit BrO column values in excess of observations and/or a false occurrence of simulated "BrO clouds" (see Fig. 8a-c). Flushing with meltwater is believed to be a primary mechanism to reduce salin- ity in the sea ice and the overlying snowpack in the summer (Holt and Digby, 1985; Eicken et al., 2002). In Barents Sea, Baffin Bay and Greenland Sea, melt-onset may occur as early as March to April with an interannual variability of more than a month (Drobot and Anderson, 2001a,b; Stroeve et al., 2006). Thus, in those areas, even on the FY sea ice the content of bromide may not be high enough in the surface snow for the formation of "BrO clouds". This appears to be linked to the underpredicted ozone mixing ratios by the model between 1-3 km a.s.l. (with an indication of air mass transport from the south) as compared to the ozonesonde data from Alert CFS on 5 April 2001 (see Sect. 3.1 and Fig. 4a). Rather too frequent ODEs simulated at Zeppelin could also be attributed to the early melt-onset, but there are other probable reasons noted in Sect. 3.1 for the poor capability of the model in simulating ODEs at Zeppelin.

Figure $9 \mathrm{~b}$ shows surface ozone mixing ratios simulated in Run 4 at 12:00 UTC for each day between 15-22 April 2001. More than half of the ice-covered sea surface in the Arctic is simulated to be overlaid with surface air containing less than $20 \mathrm{nmol} \mathrm{mol}^{-1}$ of ozone. This is consistent with three-dimensional model studies by Zeng et al. (2003, 2006), in which they inferred the 3 to 5 day mean "tropospheric" BrO columns from the GOME data and allocated all the column amounts in the lowest $300-400 \mathrm{~m}$ of the Arctic boundary layer for simulating the ODEs. In our model, surface ozone recovers to (near-) background levels $\left(>20 \mathrm{nmol} \mathrm{mol}^{-1}\right.$ ) where strong boundary-layer winds mediate a vertical and horizontal transport of ozone-rich air at 
synoptic scales as suggested previously from field observations (Gong et al., 1997; Hopper et al., 1998; Strong et al., 2002; Jacobi et al., 2010). High surface ozone levels and strong surface winds are both conducive in our model to the efficient release of reactive bromine from the surface snow, because the bromine release is triggered by ozone at greater rates, while the bromine explosion is promoted by a greater partitioning of $\mathrm{HOBr}$ (and $\mathrm{BrONO}_{2}$ to a lesser extent) for a given amount of total inorganic bromine (e.g., Tang and McConnell, 1996), and the dry deposition velocities of $\mathrm{HOBr}$ and $\mathrm{BrONO}_{2}$ increase substantially by a shear-induced turbulence in the otherwise statically stable boundary layer. The reasonable agreement between the simulated evolutions of "BrO clouds" and the GOME-SLIMCAT data indicates that, at least in April, a potential source of bromine to the atmosphere exists ubiquitously on the ice-covered ocean (especially in areas covered with the FY sea ice) across the Arctic and that the timing and location of bromine release are controlled mainly by a meteorological forcing on ozone transport and surface wind speed. The photochemical processing and movement of air mass containing " $\mathrm{BrO}$ clouds" will be smeared significantly if averaged over 3-5 days as was done by Zeng et al. (2003, 2006). This may explain why their correlation coefficients between simulated and observed surface ozone mixing ratios were somewhat smaller ( $R=0.52 \sim 0.59$ at Alert and $R=0.58 \sim 0.67$ at Barrow for the spring 2000) than our present results (see Table 4).

Under the influence of common mechanisms such as a downward diffusion near the surface and a horizontal advection from the south, the transport of ozone and sensible heat often appears to be correlated in the springtime Arctic boundary layer. Thus, on the ice-covered ocean across the Arctic, a simulated recovery of the ozone mixing ratio tends to be collocated with an increase in surface air temperature (Fig. 9a-b). This also means that the release of bromine to the atmosphere is simulated to occur at greater rates where the surface temperature is relatively high, sometimes as high as a prescribed upper limit for the bromine release from the snow in our model (e.g., $-10^{\circ} \mathrm{C}$ for Runs 3 and 6). On the other hand, a coincidence of ODEs and decreasing temperatures has been often observed at Arctic coastal sites such as Alert and Zeppelin (Bottenheim et al., 1990; Solberg et al., 1996; Tarasick and Bottenheim, 2002). Can we reconcile such observations with the behavior of our model?

Bottenheim and Chan (2006) suggested that a majority of ODEs at Alert and Zeppelin could have been initiated over sea ice several days upwind along trajectories across the central Arctic Ocean. Our model runs are not designed to reveal a link between specific "BrO clouds" and ODEs at downwind locations unambiguously. Such a link, however, is indicated for some cases from backward trajectories calculated by the $\mathrm{CMC}$ trajectory model using three-dimensional wind data from an operational GEM model (see Sect. S3 in the Supplement for details). For example, the arc-shaped "BrO cloud" that matured off the coast of Siberia during 16-
17 April 2001 appears to have been an origin of the ODE at Alert on 20 April 2001 whereas the comma-shaped "BrO cloud" that matured on 20 April 2001 appears to have carried air partially depleted in ozone to Zeppelin a few days later. Air masses depleted in ozone, once warmed adiabatically via vertical mixing while bromine chemistry is activated, can be cooled down by more than $10 \mathrm{~K}$ in a day or two as a result of infrared radiative cooling during the transport in the stable boundary layer if the underlying ice surface does not contain a lot of open/refrozen leads (Curry, 1983; Piot and von Glasow, 2008). Thus, some of the coincidence of ODEs and decreasing temperatures in the Arctic spring may reflect a long transit time after ozone is destroyed at upwind locations rather than a measure of low temperature conditions required for activating bromine chemistry.

\subsection{Additional BrO unaccounted for in the model}

So far, we have examined the simulated BrO AVCDs without any offset applied when compared with the GOMESLIMCAT tropospheric BrO VCDs. But it is probably reasonable to assume the presence of background $\mathrm{BrO}$ levels on the order of $1 \times 10^{13}$ molecule $\mathrm{cm}^{-2}$ (or about $0.5 \sim 1 \mathrm{pmol} \mathrm{mol}^{-1}$ ) in the Arctic troposphere arising from sources neglected in our model runs such as the photodegradation of organic bromine and volatilization from sea-salt aerosols (Fitzenberger et al., 2000; Yang et al., 2005; Hendrick et al., 2007). The background BrO levels in the free troposphere can be underpredicted also because a moist convection over open leads and polynyas in the sea ice is underrepresented in large-scale meteorological models but would likely carry reactive bromine compounds as well as moisture upwards from the near-surface boundary layer quite efficiently (McElroy et al., 1999; Salawitch et al., 2010).

In addition, the $\mathrm{BrO}$ concentrations in the lowermost stratosphere are most likely underestimated by the SLIMCAT model used here because Chipperfield et al. (2005) did not account for very short-lived (VSL) organic bromine compounds such as $\mathrm{CH}_{2} \mathrm{Br}_{2}$ and $\mathrm{CHBr}_{3}$ but represented the decomposition of organic source gases solely by $\mathrm{CH}_{3} \mathrm{Br}+\mathrm{OH} / h v$. The "mean age of air", or an average time spent by air parcels after entering the stratosphere, is about 6 to 24 months in the Arctic lowermost stratosphere (e.g., Chipperfield, 2006), so that a fraction of $\mathrm{CH}_{3} \mathrm{Br}$ already decomposed into inorganic bromine may change significantly with altitude (Dvortsov et al., 1999). On the other hand, two main VSL organic bromine compounds, $\mathrm{CHBr}_{3}$ and $\mathrm{CH}_{2} \mathrm{Br}_{2}$, have photochemical lifetimes of around 30 days and 6 months, respectively, and are believed to enter the stratosphere in the tropics via deep convective transport as well as relatively slow large-scale upwelling motion in the tropical troposphere (Hossaini et al., 2010). It is therefore reasonable to assume that these VSL organic bromine compounds are totally converted to inorganic bromine by the time air is mixed to high latitudes in the stratosphere. Most recent 

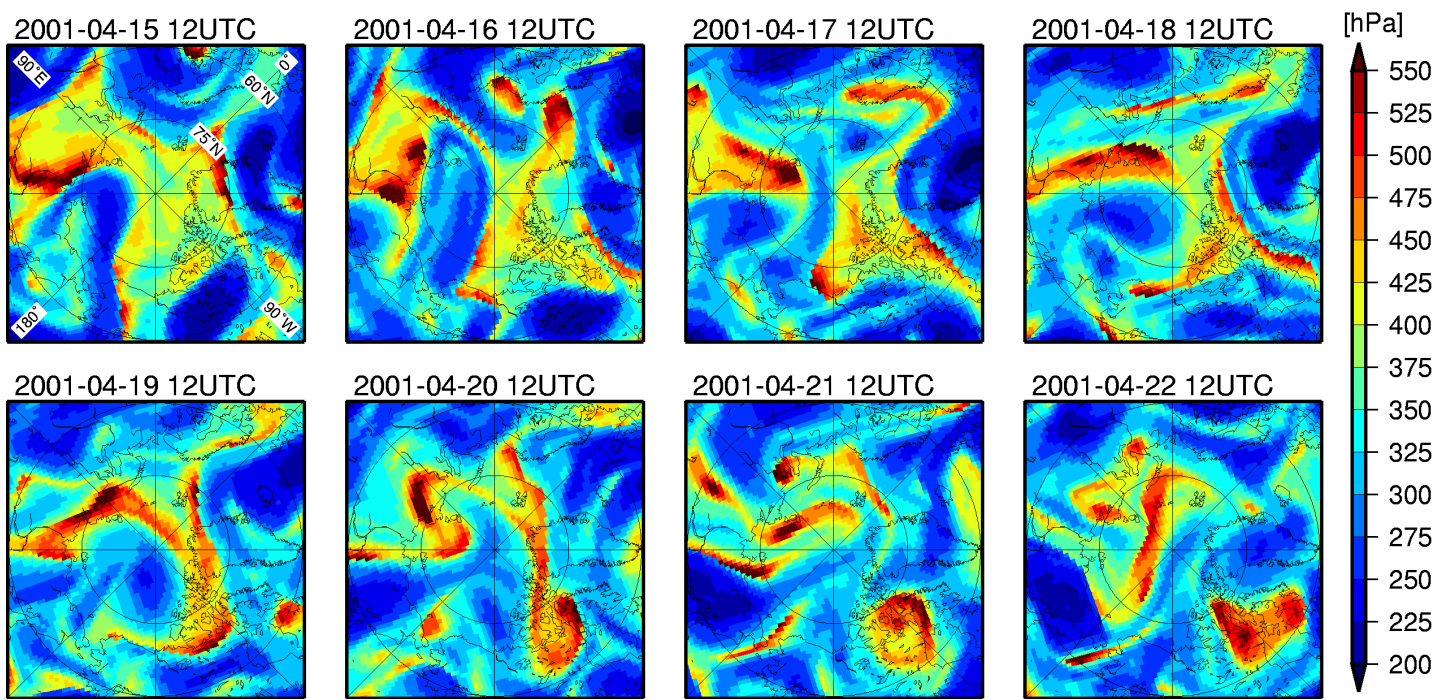

Fig. 11. Dynamical tropopause pressure levels (in hPa) defined by the 2 PVU surface at 12:00 UTC for each day between 15-22 April 2001 simulated by the GEM model.

stratospheric chemical transport models (including the upgraded version of SLIMCAT) assume a contribution of VSL organic bromine compounds to the stratospheric $\mathrm{Br}_{\mathrm{y}}$ loading in the range of $4 \sim 10 \mathrm{pmol} \mathrm{mol}^{-1}$ to reconcile simulated $\mathrm{BrO}$ levels with measurements from various platforms (e.g., Feng et al., 2007; Theys et al., 2009; Liang et al., 2010; Salawitch et al., 2005, 2010; Sioris et al., 2006; McLinden et al., 2010). There are also possible numerical issues with offline transport models and the use of analyzed winds (e.g., Schoeberl et al., 2003; Monge-Sanz et al., 2007). This may result in a significant underprediction of the mean age-of-air in the extra-tropical lower stratosphere and therefore degrade the simulation of $\mathrm{Br}_{\mathrm{y}}$ profiles, resulting in lower predicted $\mathrm{Br}_{\mathrm{y}}$.

As shown in Fig. 11 by changes in dynamical tropopause levels (defined here by the 2 PVU surface) at 12:00 UTC for each day between 15-22 April 2001 simulated in the GEM model, the vertical displacement of the tropopause is strongly associated with synoptic disturbances controlling surface meteorology. Among the most striking is the collocation of lowered tropopause levels down to about $500 \mathrm{hPa}$ encompassing from Canadian Arctic Archipelago to Hudson Bay with high BrO VCD values in the GOME-SLIMCAT data (Fig. 8a) during 20-22 April. Depending on the amount of stratospheric $\mathrm{Br}_{\mathrm{y}}$ originating from VSL organic bromine compounds, such dynamical variability in the lowermost stratosphere could account for a significant part of variability in total $\mathrm{BrO}$ columns even in the springtime Arctic (Salawitch et al., 2010). For instance, a constant $\mathrm{BrO}$ mixing ratio at $3 \mathrm{pmol} \mathrm{mol}^{-1}$ between $200-500 \mathrm{hPa}$ levels (which correspond to a range of variations in the dynamical tropopause level shown in Fig. 11) will translate to a $\mathrm{BrO}$ column of $1.9 \times 10^{13}$ molecule $\mathrm{cm}^{-2}$. Together with the tropospheric $\mathrm{BrO}$ background, this could help reconcile the $\mathrm{BrO}$ columns simulated by the GEM-AQ model towards a better agreement with the GOME-SLIMCAT data. According to photochemical box model calculations (McLinden et al., 2010), about $50 \%$ of $\mathrm{Br}_{\mathrm{y}}$ exists as $\mathrm{BrO}$ in the Arctic lowermost stratosphere in the middle of the day during this time of the year. Thus, $3 \mathrm{pmol} \mathrm{mol}^{-1}$ of extra $\mathrm{BrO}$ between $200-500 \mathrm{hPa}$ is equivalent to adding $6 \mathrm{pmol} \mathrm{mol}^{-1}$ of stratospheric $\mathrm{Br}_{\mathrm{y}}$ (either originating from VSL organic bromine compounds or accommodating numerical issues with tracer transport) to what was simulated by the SLIMCAT model from Chipperfield et al. (2005), well within the uncertainty range quoted above.

Here we show how BrO columns simulated by GEM-AQ (Run 3) can be corrected by adding extra $\mathrm{BrO}$ in the troposphere and/or in the lowermost stratosphere to reconcile with the GOME-SLIMCAT data. First, adding the extra $1 \mathrm{pmol} \mathrm{mol}^{-1}$ of background $\mathrm{BrO}$ in the entire troposphere (from the Earth surface up to the dynamical tropopause) removes an offset for the linear regression between GEMAQ BrO AVCDs and GOME-SLIMCAT tropospheric BrO VCDs (Fig. 12a), but slightly reduces the correlation coefficient between the two quantities. Next, adding the extra $0.5 \mathrm{pmol} \mathrm{mol}^{-1}$ of background $\mathrm{BrO}$ in the entire troposphere and $1 \mathrm{pmol} \mathrm{mol}^{-1}$ of $\mathrm{BrO}$ from the dynamical tropopause up to the $100 \mathrm{hPa}$ level removes the offset for the linear regression and also slightly improves the correlation coefficient. Adding the extra $0.5 \mathrm{pmol} \mathrm{mol}^{-1}$ of background $\mathrm{BrO}$ in the entire troposphere and $3 \mathrm{pmol} \mathrm{mol}^{-1}$ of $\mathrm{BrO}$ from the dynamical tropopause up to the $200 \mathrm{hPa}$ level improves the correlation coefficient to 0.71 and, moreover, the slope of the linear regression is increased from 0.40 to 0.58 . This reconciliation procedure works quite well over wide areas from middle to high latitudes of the Northern Hemisphere 

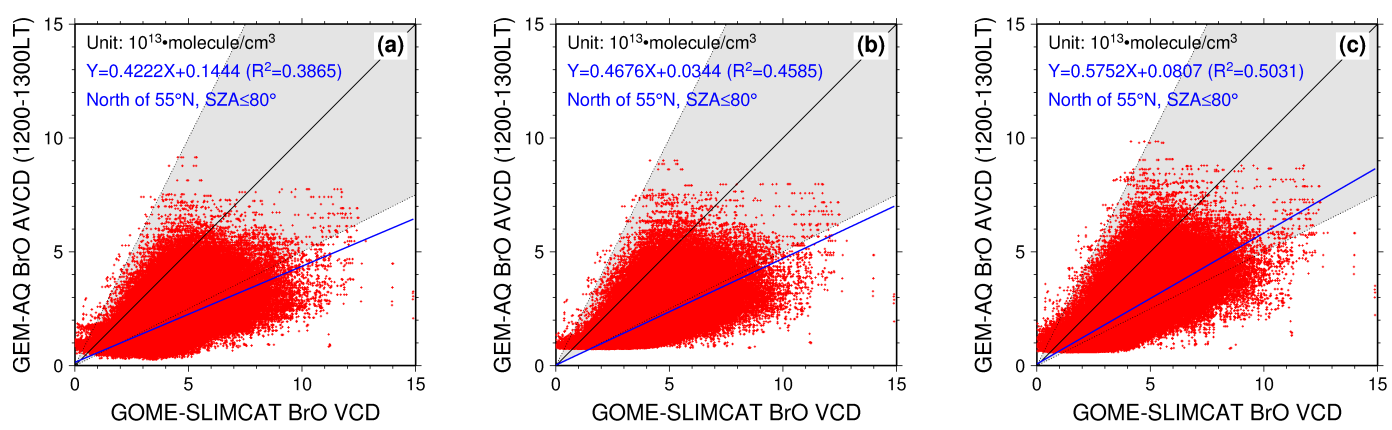

Fig. 12. The same as Fig. 10 but GEM-AQ BrO AVCDs from Run 3 are recalculated by adding extra BrO to the original model output: (a) $1 \mathrm{pmol} \mathrm{mol}^{-1}$ from the surface up to GEM's dynamical tropopause; (b) $0.5 \mathrm{pmol} \mathrm{mol}^{-1}$ from the surface up to GEM's dynamical tropopause and $1 \mathrm{pmol} \mathrm{mol}^{-1}$ from the dynamical tropopause up to the $100 \mathrm{hPa}$ level; and (c) $0.5 \mathrm{pmol} \mathrm{mol}^{-1}$ from the surface up to GEM's dynamical tropopause and $3 \mathrm{pmol} \mathrm{mol}^{-1}$ from the dynamical tropopause up to the $200 \mathrm{hPa}$ level.

(see Figs. 13-14). But the conclusion that "BrO clouds" are boundary-layer phenomena still appears robust particularly over the eastern and central Arctic Ocean, because the horizontal structure of the vertical tropopause displacement (Fig. 11) does not necessarily agree with that of the enhanced $\mathrm{BrO}$ VCDs in the GOME-SLIMCAT data (Fig. 8a).

\subsection{Potential influences from temperature and acidity on bromine activation in the polar boundary layer}

Our model simulations are consonant with the idea that reactive bromine is released from the saline snow/ice surface apparently at temperatures as high as $-10 \sim-15^{\circ} \mathrm{C}$, or possibly even higher, over an extensive area across the springtime Arctic. However, the issue is not clear cut as there are results which suggest that a heterogeneous bromine activation in the polar boundary layer is favored at lower temperatures. For example, the concentrations of $\mathrm{Br}^{-}$relative to $\mathrm{Cl}^{-}$are increased in freezing salt solutions especially below $-20^{\circ} \mathrm{C}$ due to the precipitation of $\mathrm{NaCl} \cdot 2 \mathrm{H}_{2} \mathrm{O}$ and $\mathrm{MgCl}_{2} \cdot 12 \mathrm{H}_{2} \mathrm{O}$ (Koop et al., 2000; Morin et al., 2008). Also, the equilibrium constants of Reactions (R10) would shift towards a formation of $\mathrm{Br}_{2}$ as suggested by Sander et al. (2006). Carbonate precipitation from a freezing brine (Dieckmann et al., 2010; Sander and Morin, 2010) leads to a decrease in total alkalinity of the brine, increasing a likelihood of acid-assisted bromine release from the saline snow. For the recycling of gaseous bromine reservoirs into photolabile species, colder temperatures appear to increase the capacity of aerosols to accommodate reactants from the gas phase (Piot and von Glasow, 2008). However, in the latter case, if the aerosol substrate retains a liquid water content as large as cloud water droplets, it may rather end up deactivating bromine chemistry by a dilution of reactants in the condensed phase after taken up from the gas phase (Piot and von Glasow, 2008). In this context we note the occurrence of mixed-phase clouds is very common in the Arctic boundary layer. Their liquid water fraction increases, in general, notably with tempera- ture between $-30 \sim-10^{\circ} \mathrm{C}$ (e.g., Shupe et al., 2006) and thus the bromine activation process by any of these mechanisms would be offset. In favor of a mechanism that is active at warmer temperatures, we note that photolysis of dissolved impurities such as $\mathrm{H}_{2} \mathrm{O}_{2}, \mathrm{NO}_{3}^{-}$and unknown organic chromophores leads to an in-snow formation of $\mathrm{OH}$ radicals (e.g., Anastasio and Jordan, 2004; Anastasio et al., 2007). These may subsequently produce $\mathrm{Br}_{2}$ in the $\mathrm{Br}^{-}$-containing snow especially if it is acidic (e.g., Abbatt et al., 2010). Laboratory experiments have shown that such photolytic reactions will proceed at greater yields of the products, viz. $\mathrm{OH}$ and $\mathrm{Br}_{2}$, with increasing temperature in the frozen solutions ( $\mathrm{Chu}$ and Anastasio, 2003, 2005; Abbatt et al., 2010). Thus, depending on which physical and chemical mechanisms actually exert a major influence on the activation of bromine chemistry, reactive bromine release from the snow and subsequent ozone depletion in the atmospheric boundary layer will respond to changing temperature and acidity conditions quite differently.

In the end our scheme is semi-empirical while attempting to incorporate the main observational features of bromine release, viz. it is valid across the entire Arctic, can be active up to $-10^{\circ} \mathrm{C}$ or higher (e.g., Bottenheim et al., 2009), and appears to be limited by the disappearance of ozone (e.g., Impey et al., 1997; Morin et al., 2005). By employing a simple scheme that is controlled and limited by an uptake of $\mathrm{O}_{3}$, $\mathrm{HOBr}$ and $\mathrm{BrONO}_{2}$ to the snow surface via dry deposition from the atmosphere, it is possible that the model fortuitously approximated the whole processes of greater complexity occurring in reality. However, the reasonable success of our simulation with regard to a synoptic-scale variability in the lower-tropospheric concentrations of $\mathrm{BrO}$ and $\mathrm{O}_{3}$ suggests that it has captured some of the features of the complex processes occurring during the evolution of bromine and the destruction of ozone.

Oum et al. (1998) conducted laboratory experiments for a reactive ozone uptake on the frozen salt solution at $\mathrm{pH} 8$ for temperatures between $-5 \sim-1{ }^{\circ} \mathrm{C}$. The rate of the $\mathrm{Br}_{2}$ 
(a) RUN 3

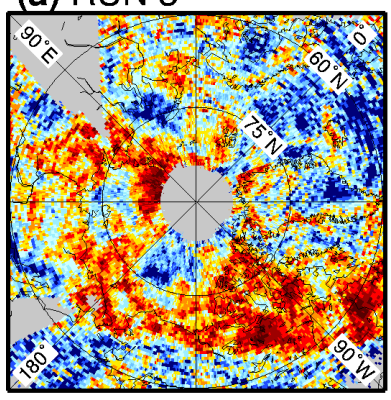

\section{(d) RUN 6}

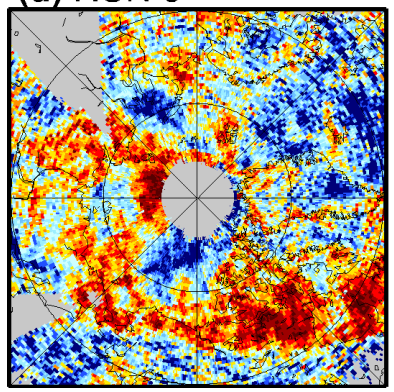

(b) RUN 4

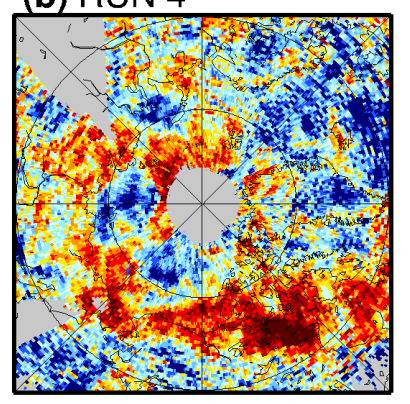

(e) RUN 7

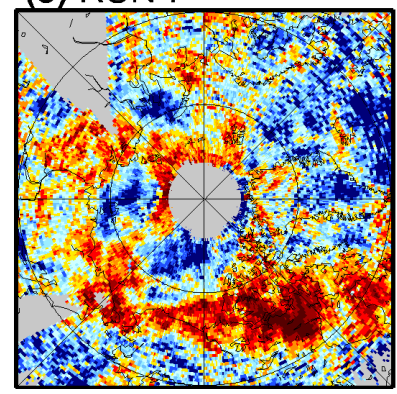

(c) RUN 5

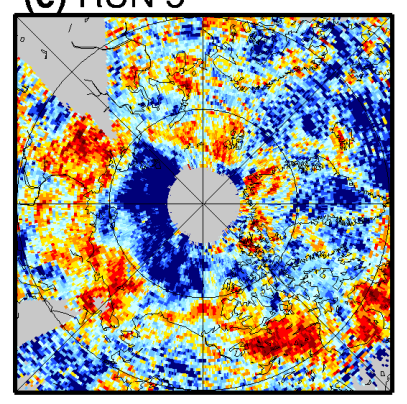

\section{(f) RUN 8}

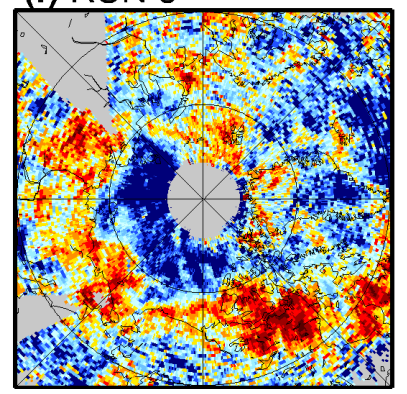

$R$

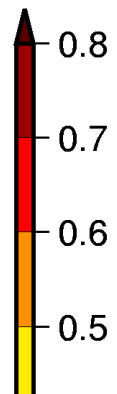

$-0.4$

$-0.3$

$-0.2$

$-0.1$

Fig. 13. Spatial distributions of temporal correlation coefficients between GEM-AQ BrO AVCDs and GOME-SLIMCAT tropospheric BrO VCDs in April 2001: (a) Run 3, (b) Run 4, (c) Run 5, (d) Run 6, (e) Run 7, and (f) Run 8. The GEM-AQ output (at the resolution of $0.88^{\circ} \times 0.88^{\circ}$ in the Arctic core) is regridded to $0.5^{\circ} \times 0.5^{\circ}$ used for the GOME-SLIMCAT dataset. Shaded by gray where the number of samples is less than 16 .

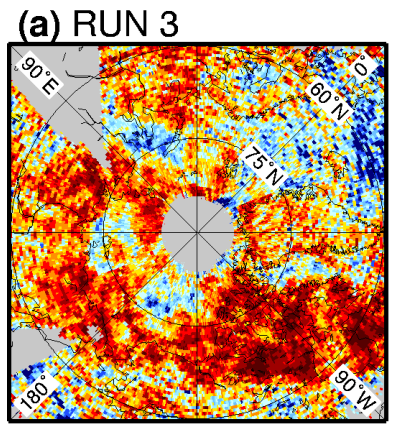

\section{(d) RUN 6}

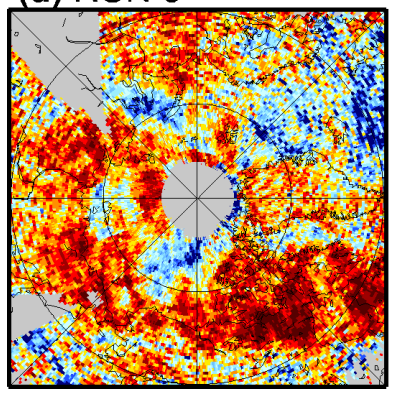

(b) RUN 4

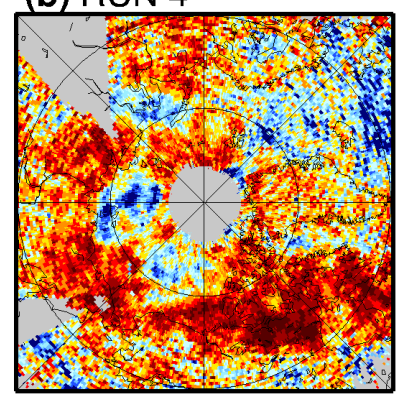

(e) RUN 7

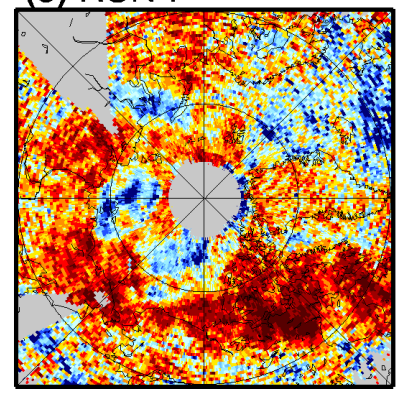

(c) RUN 5
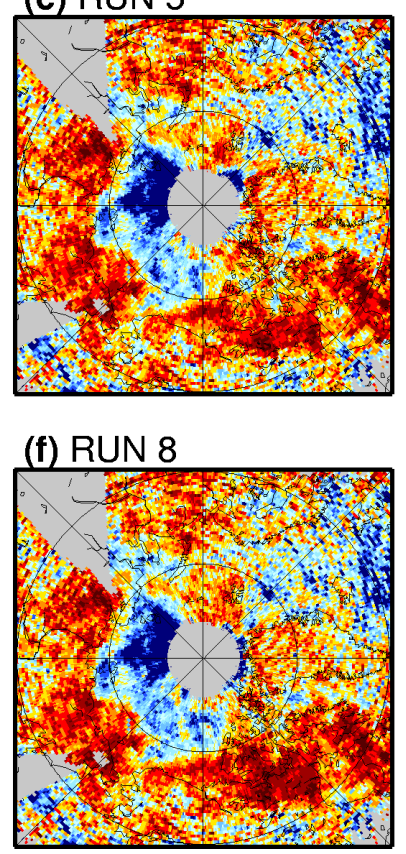

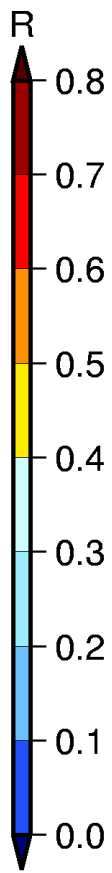

Fig. 14. The same as Fig. 13 but for GEM-AQ BrO AVCDs recalculated by adding extra BrO to the original model output, viz. $0.5 \mathrm{pmol} \mathrm{mol}^{-1}$ from the surface up to GEM's dynamical tropopause and $3 \mathrm{pmol} \mathrm{mol}^{-1}$ from the dynamical tropopause up to the $200 \mathrm{hPa}$ level. 
(a) Net $\mathrm{Br}_{\mathrm{y}}$ Exchange

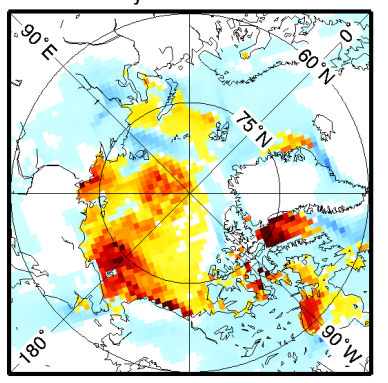

(d) Net $e+f$

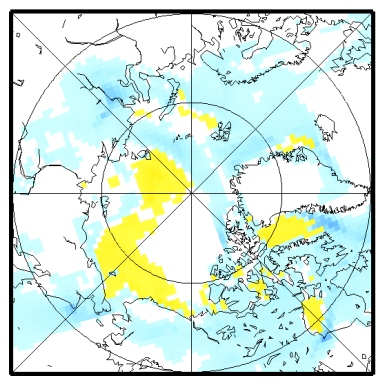

(b) $\mathrm{O}_{3} \rightarrow \mathrm{Br}_{2}$

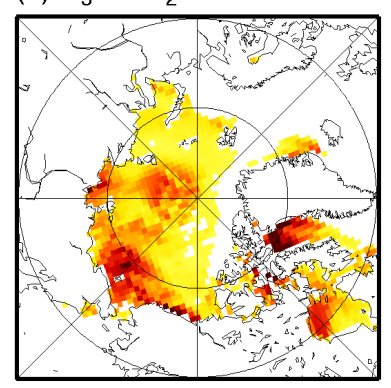

(e) $\mathrm{HOBr} / \mathrm{BrONO}_{2} \rightarrow \mathrm{Br}_{2}$

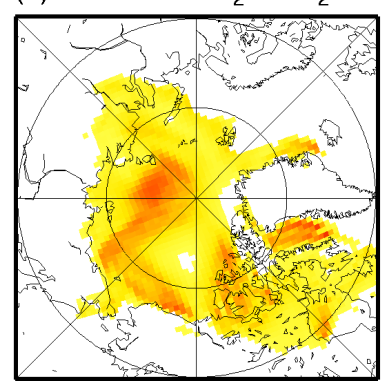

(c) Wet Deposition of $\mathrm{HBr}$

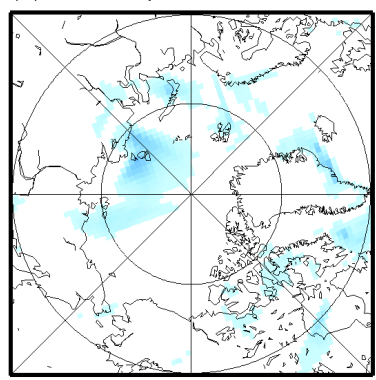

(f) Dry Deposition of $\mathrm{Br}_{\mathrm{y}}$

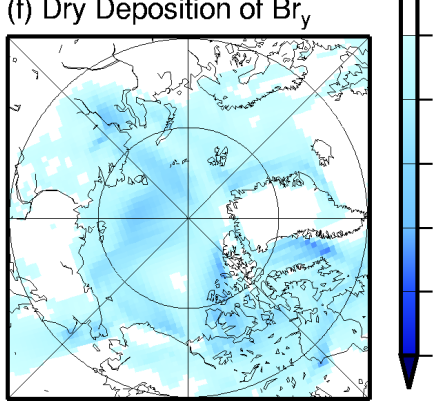

5.0

4.0

3.0

2.0 중

0.1 틍

-0.1 है

-1.0 융

$-2.0 \stackrel{\circ}{\circ}$

$-3.0$

$-4.0$

$-5.0$

Fig. 15. The net air-surface exchange rate of bromine integrated over $24 \mathrm{~h}$ between 00:00-24:00 UTC on 20 April 2001 as simulated in Run 3 and the separate contribution of each operating mechanism: (a) the total net exchange of all the inorganic bromine species; (b) $\mathrm{Br}_{2}$ release via dry deposition of ozone on the FY sea ice; (c) wet deposition of $\mathrm{HBr}$ integrated over the atmospheric column; (d) the net rate of air-surface bromine exchange via "explosion" chemistry as represented by the sum of (e) and (f); (e) $\mathrm{Br}_{2}$ release via dry deposition of $\mathrm{HOBr}$ and $\mathrm{BrONO}_{2}$; and (f) dry deposition of all the inorganic bromine species. Positive values represent a net release to the atmosphere whereas negative values represent a net loss from the atmosphere (in atom $(\mathrm{Br}) \mathrm{cm}^{-2} \mathrm{day}^{-1}$ ).

release estimated from their experimental result was apparently not high enough to explain the abundance of reactive bromine observed in the field, although it could effectively trigger the "bromine explosion". Oldridge and Abbatt (2011) found a significant increase in the reactive uptake coefficient $(\gamma)$ of ozone onto a frozen salt solution at $\mathrm{pH} 5.6$ by raising temperature from $-40{ }^{\circ} \mathrm{C}$ to $-15^{\circ} \mathrm{C}$. The $\gamma$ value close to the higher end of what Oldridge and Abbatt reported had been obtained by Wren et al. (2010) for the heterogeneous surface reaction of ozone on a non-acidified frozen $\mathrm{NaBr}$ solution at $-20^{\circ} \mathrm{C}$. The latter authors showed that the reaction proceeds apparently at a similar rate at $-10^{\circ} \mathrm{C}$ as well. However, the $\gamma$ values on the order of $10^{-8}$ as derived in these studies again indicate that the heterogeneous surface reaction of ozone by itself is unlikely to account for a buildup of reactive bromine fast enough as observed in the field. Clearly, as discussed later in Sect. 3.5, the semi-empirical reactive uptake of ozone on the snow surface in our model is a proxy for other more complex processes which can be parameterized as functions of the surface ozone level.

For the reactive uptake of $\mathrm{HOBr}$ onto frozen salt solutions, previous laboratory experiments have been conducted only at temperatures between $-43 \sim-20^{\circ} \mathrm{C}$ (Kirchner et al., 1997; Huff and Abbatt, 2002; Adams et al., 2002). At these temperatures, acidity is not required for the release of $\mathrm{Br}_{2}$ and/or $\mathrm{BrCl}$ to take place efficiently via $\mathrm{HOBr}$ uptake on the frozen sea-salt solution unlike at room temperature (Fickert et al., 1999). For the reactive uptake of $\mathrm{BrONO}_{2}$, experimental studies have not been conducted at the temperature and substrate conditions pertinent to polar snowpack. Bulk solutions melted from Arctic snowfall and snowpack have been found to be moderately acidic during the springtime (Gjessing, 1977; Semb et al., 1984; Cho et al., 2002; Toom-Sauntry and Barrie, 2002; Douglas and Sturm, 2004), reflecting the long-range transport of sulfur and nitrogen oxides of anthropogenic origin. It thus seems that an alkaline brine on the snowpack will often be acidified to levels necessary for reactive bromine release via the mechanism studied by Fickert et al. (1999). In the springtime Arctic boundary layer, acidic gases and aerosols are transported mainly from Eurasia (e.g., Christensen, 1997). If the bromine release from the saline snow is prone to proceed via acid-assisted reactions with increasing temperature, it may explain the potential regional difference in activity implied from our model runs; the model performed best where the temperature threshold for bromine release was relaxed and raised to $T_{\mathrm{c}}=-10^{\circ} \mathrm{C}$ (Run 3) for simulating $\mathrm{BrO}$ columns particularly over the eastern and central Arctic Ocean, while surface ozone at Barrow was simulated somewhat better where $T_{\mathrm{c}}=-15^{\circ} \mathrm{C}$ was assumed (Run 4). 
Since the volume and chemical composition of a liquidlike layer at the surface of frozen salt solutions change substantially with temperature (e.g., Cho et al., 2002; Abbatt, 2003), it is desirable to perform laboratory experiments consistently to explore if any changes occur in the reactive uptake coefficient and product yields of each heterogeneous reaction of interest over wide ranges of substrate temperature and acidity conditions for characterizing the chemistry of halogens in the polar boundary layer.

\subsection{Budget analysis of the parameterized mechanisms for air-surface bromine exchange}

As discussed in Sect. 3.2, reactive bromine release from the snow/ice surface is strongly influenced by changing meteorological conditions. Figure 15a shows the net surface flux of $\mathrm{Br}_{\mathrm{y}}$ integrated over $24 \mathrm{~h}$ on 20 April 2001 as simulated in Run 3. The maximum net surface-to-air flux of $\mathrm{Br}_{\mathrm{y}}$ was simulated to reach greater than $4 \times 10^{13}$ atom $(\mathrm{Br}) \mathrm{cm}^{-2}$ day $^{-1}$ in the eastern and central Arctic Ocean as well as in between Canadian Arctic Archipelago, contributing to a build up of "BrO clouds" located in those areas on the same day (Fig. 8a-b). Note, however, that the net surface-to-air $\mathrm{Br}_{\mathrm{y}}$ flux was most likely overestimated in Baffin Bay (see Sect. 3.3). A breakdown of the total net flux from each contributing mechanism (Fig. 15b-f) points to a revealing result from our simulation. Contrary to our original expectation, the ozone trigger (Fig. 15b) contributed primarily to a build up of atmospheric bromine whereas the bromine explosion caused by $\mathrm{HOBr}$ and $\mathrm{BrONO}_{2}$ (Fig. 15e) was of secondary importance in the simulation. Thus the tuning parameter for the ozone trigger ( $\Phi_{1}=0.075$, see Sect. 2.3$)$ seems to be a reasonable measure of the complex processes that actually occur at (or near) the air-snow interface in the Arctic environment.

Sander et al. (2006) suggested that wind-abraded grains from the saline snowpack (drifting/blowing snow) would serve as a major salinity source to the polar boundary layer which would then lead to the bromine explosion and ODEs. Such a process seems consistent with ground-based optical measurements at Neumayer station, Antarctica by Frieß et al. (2004). They found enhanced overhead BrO columns often occurring simultaneously with enhanced slant columns of $\mathrm{O}_{2}$ dimer (as an indicator of aerosol multiple scattering). Jones et al. (2009) also reported a compelling case where blowing snow was most likely involved in the occurrence of high BrO column and surface ozone depletion from groundbased observations at Halley station, Antarctica. Also in the Arctic, the occurrence of ODEs is sometimes accompanied by increased concentrations of sea-salt aerosols (e.g., Hopper and Hart, 1994). However, as has been pointed out frequently (e.g., McConnell et al., 1992), the concentrations of bromine in either gaseous or particulate form are generally far in excess of what could be expected from sea-salt composition (or sodium) in aerosols during the Arctic spring at least near coastal/island sites such as Alert, Barrow and $\mathrm{Ny}$ Ålesund (Berg et al., 1983; Sturges and Barrie, 1988; Oltmans et al., 1989; Barrie et al., 1994; Impey et al., 1997; Lehrer et al., 1997). This indicates that a source other than airborne sea-salt aerosols should account for most of the reactive bromine observed in the air. Nonetheless, Yang et al. $(2008,2010)$ implemented an algorithm to simulate gaseous bromine release from sea-salt aerosols that originate from a sublimation of wind-blown snow after detached from saline snowpack in their three-dimensional tropospheric chemical transport model with bromine chemistry. They concluded that the amount of bromine originating from the wind-blown snow could be abundant enough to account for the occurrence of "BrO clouds" in the springtime Arctic boundary layer. A key assumption by Yang et al. was that $\mathrm{Br}^{-}$is depleted relative to $\mathrm{Na}^{+}$in the snow-derived sea-salt aerosols to provide a source of gaseous bromine. This, however, is contradictory to aerosol chemistry observations in the Arctic cited above, implying that the aerosols had, de facto, already been "seeded" with bromine sufficient to cause the gaseous "BrO clouds" in the Yang et al. model. It still seems that the bromine release occurs directly from the wind-blown snow before sublimation, as suggested by Jones et al. (2009). The inclusion of this process could have raised simulated $\mathrm{BrO}$ columns particularly when windy in our model to give a further improvement in the correlation and the slope of linear regression between simulated and measured $\mathrm{BrO}$ columns discussed in Sect. 3.3. In our present setup, the wind-induced enhancement of the efficiency for bromine release from the snow occurs mainly by an increase in dry deposition velocities for $\mathrm{HOBr}$ and $\mathrm{BrONO}_{2}$ as a result of decrease in aerodynamic resistance. However, its effect on the overall bromine release from the snow is probably not large enough to approximate the process associated with blowing/drifting snow.

On the other hand, if the bromine explosion takes place in the interstitial air of the snowpack, it can produce a large amount of $\mathrm{Br}_{2}$ while ozone imported from the overlying atmosphere is lost via gas-phase bromine chemistry. This process appears likely to be happening because ozone destruction in the interstitial air, often enhanced by sunlight, has been inferred from ozone measurements in the polar snowpack (Peterson and Honrath, 2001; Albert et al., 2002; Helmig et al., 2007a). Our air-snowpack interaction scheme implicitly expresses such a linkage by relating the dry deposition of ozone onto the snow surface to the release of $\mathrm{Br}_{2}$ into the atmosphere. We note that the molar yield of $\mathrm{Br}_{2}$ released to the atmosphere per mole of $\mathrm{O}_{3}$ imported from the ambient air and destroyed via gas-phase bromine chemistry in the interstitial air of snowpack could be as high as $100 \%$, if all the $\mathrm{BrO}$ radicals formed via Reaction (R1) undergo subsequent reactions only to form $\mathrm{HOBr}$ and $\mathrm{BrONO}_{2}$ in the gas phase, heterogeneously converted to $\mathrm{Br}_{2}$ (Reactions R4-R5) and finally released to the atmosphere. The molar yield of $\mathrm{Br}_{2}$ could be even higher if there is a photochemical ozone production in the interstitial air as a result of 
$\mathrm{NO}_{2}$ and/or HONO release via $\mathrm{NO}_{3}^{-}$photolysis in the snowpack surface (e.g., Grannas et al., 2007), but it would more likely be smaller than $100 \%$ considering a possibility of alternative reaction pathways such as the self-reaction of $\mathrm{BrO}$ (Reaction R2) to destroy ozone catalytically and the formation of $\mathrm{HBr}$ followed by its uptake to the ice surface before $\mathrm{Br}_{2}$ is exported to the overlying ambient air. The pumping of air into and out of the snowpack is expected to increase with surface wind speed (e.g., Cunningham and Waddington, 1993), perhaps facilitating the $\mathrm{Br}_{2}$ release from the snowpack if it is associated indeed with the ozone loss in the interstitial air. While such a wind-speed dependence is virtually absent for the ozone trigger in our semi-empirical scheme, photochemistry in the snowpack interstitial air could thus have a strong connection to the evolution of bromine in the polar boundary layer.

In summary, given the agreement of the simulations with observations and the nature of the semi-empirical ozone trigger in our model, it seems quite plausible to assume that bromine release and ozone destruction in the near-surface ambient air loaded with wind-blown snow and/or in the snowpack interstitial air are approximately collocated. A dependence on the wind speed associated with these processes would likely be underrepresented in our present model configuration. This could be another reason for rather too low BrO columns simulated by our model, even after applying the offset to correct possible contributions from $\mathrm{BrO}$ near the tropopause, as compared to the GOME-SLIMCAT data (see Sect. 3.2-3.3).

\section{Conclusions}

Gas-phase and heterogeneous bromine chemistry and a simple scheme of air-snowpack chemical interactions have been implemented in an online air-quality model, GEM-AQ, to simulate the production of reactive bromine species and the destruction of ozone in the springtime Arctic boundary layer. A comparison of model runs with observations for April 2001 suggests that $\mathrm{Br}^{-}$was retained in the snowpack ubiquitously on sea ice across the high Arctic and that it was accessible to the overlying ambient air and led to the release of reactive bromine gases such as $\mathrm{Br}_{2}$. The timing and location of the bromine release appeared to be controlled mainly by the horizontal and vertical transport of ozone-rich air masses, which facilitate the oxidation of $\mathrm{Br}^{-}$in the snowpack perhaps via secondary oxidants (such as $\mathrm{HOBr}$ ) formed in chain reactions involving ozone. Such transport events normally result from synoptic disturbances, which also break up the surface temperature inversion and raise temperatures at the air-snowpack interface. The results indicate that the snowpack could be actively releasing bromine at temperatures as high as $-10 \sim-15^{\circ} \mathrm{C}$ or possibly even higher. This, however, does not necessarily preclude the importance of lower temperature conditions for the Arctic bromine chem- istry, because some pre-conditioning processes such as a brine expulsion on the top of refreezing leads may occur only below $-20^{\circ} \mathrm{C}$ (Martin et al., 1996). While the opening and refreezing of leads and the concomitant brine expulsion onto the sea ice are probably the most active in the winter, this activity seems to be significant also during the spring (Fett et al., 1994). The overall process, viz. from the brine expulsion on the sea ice to the bromine release into the atmosphere, may be occurring at ambient temperatures changing extensively even at the timescale of synoptic disturbances. The present model study also corroborates conclusions from other recent studies that indicated a critical role of transport processes associated with synoptic disturbances in the occurrence of high tropospheric $\mathrm{BrO}$ column events in the Arctic (Begoin et al., 2010) and in the Antarctic (Jones et al., 2010) using the variability in the observed ozone and $\mathrm{BrO}$ levels.

In our scheme of air-snow chemical interactions, the majority of bromine input to the atmosphere occurs via a semiempirically formulated coupling between $\mathrm{Br}_{2}$ release and the dry deposition of ozone on the snow/ice surface. The success of this parameterization in capturing much of the synoptic behavior of $\mathrm{BrO}$ indicates that it is necessary to scrutinize the chemical and physical, presumably multiple-step, processes involved in the transformation of $\mathrm{Br}^{-}$at the snow/ice surface into volatile gaseous bromine species. We speculate that the pumping of ambient air into and out of the snowpack (e.g., McConnell et al., 1992) and the blowing/drifting snow lofted from the surface (e.g., Sander et al., 2006) are both playing a role especially under the strong surface wind.

The evaluation of our model scenarios indicated the likelihood that physical and/or chemical conditions on the FY sea ice are more advantageous for $\mathrm{Br}_{2}$ release relative to the conditions on the MY sea ice. While the FY sea ice is certainly more prone to the formation of open and refrozen leads as a source of salinity than the MY sea ice (e.g., Kwok, 2006), the chemically labile nature of bromine assists its transport over an extended distance via successive depositions and re-emissions between the atmosphere and the surface snow (Simpson et al., 2005). Clearly, a better understanding of the "life cycle" of bromine in the polar ocean-atmosphereseaice-snowpack system will increase our capacity to simulate bromine chemistry in the high-latitude boundary layer after polar sunrise towards the beginning of the summer and also to predict how it will change under a different climate in the future (e.g., Voulgarakis et al., 2009).

In this study, we did not deal with the chemistry of chlorine and iodine. While they appear rather unimportant for ozone budget in the springtime Arctic boundary layer, it may not necessarily be the case under the future climate. Even under the present climate, reactive chlorine chemistry is known to be very important for the loss of hydrocarbons (but not ozone) in the springtime polar boundary layer. However, quite often chlorine activation is neither collocated nor synchronized with bromine activation and the mechanism is quite uncertain (e.g., Impey et al., 1997; Tuckermann et al., 
1997). The rare occurrence of high IO levels in the springtime Arctic is probably related to a small source strength of organic iodine compounds of marine biogenic origin (Mahajan et al., 2010). However, it is not known whether this will remain the same under the future climate with a significantly reduced thickness of sea ice and the predominance of the FY sea ice (Overland and Wang, 2007; Wang and Overland, 2009). There is also a suggestion that iodide $\left(\mathrm{I}^{-}\right)$could catalyze the release of bromine and chlorine from sea-salt solutions in certain conditions (Enami et al., 2007). Hence it is potentially important to understand the source and the chemistry of chlorine, bromine and iodine altogether to project the future of the chemical environment in the Arctic boundary layer.

\section{Appendix A}

\section{Air mass factors applied to simulated $\mathrm{BrO}$ profiles}

Vertically-resolved, or box, air mass factors $\left(\mathrm{AMF}_{\mathrm{b}}\right)$ are calculated using the VECTOR (VECTor Orders-of-scattering Radiative transfer) model (McLinden et al., 2002, 2006). VECTOR accounts for the diurnal variation in $\mathrm{BrO}$ concentrations along the incoming solar beam, an effect that becomes important as twilight is approached, and was found to agree well with other models in an AMF-intercomparison study (Wagner et al., 2007). The $\mathrm{AMF}_{\mathrm{b}}$ values are calculated by successively perturbing the $\mathrm{BrO}$ concentration in a layer and assessing its impact on the $350 \mathrm{~nm}$ nadir radiance.

A background atmosphere for 15 April at $65^{\circ} \mathrm{N}$ is employed. The profile is a combination of a photochemical box model-calculated stratospheric $\mathrm{BrO}$ profile (McLinden et al., 2000, 2010), and $1 \mathrm{pmol} \mathrm{mol}^{-1} \mathrm{BrO}$ in the troposphere. The use of a single $\mathrm{BrO}$ profile is justified as the AMFs are vertically resolved and hence independent of the profile shape, and also because $\mathrm{BrO}$ is optically thin. A background level of stratospheric sulfate aerosol at the optical depth of 0.02 and a tropospheric aerosol profile with a number density profile constant in altitude at the optical depth of 0.2 (Tomasi et al., 2007) are assumed. Based on this, a look-up table is generated as a function of altitude (1 km increments), surface albedo ( 0.2 increments), and solar zenith angle ( 13 between $0^{\circ}$ and $90^{\circ}$, with the majority between $75^{\circ}$ and $90^{\circ}$ ). A viewing zenith angle $\left(\theta_{\mathrm{v}}\right)$ is set to $0^{\circ}$ (pure nadir geometry). Multilinear interpolation is used to determine the $\mathrm{AMF}_{\mathrm{b}}$ for a given altitude $(z)$, surface albedo $(\alpha$, taken from broadband albedo for solar radiation in the GEM model), and solar zenith angle $\left(\theta_{\mathrm{s}}\right)$.

Model apparent slant column densities (ASCDs) are then calculated by vertically integrating the $\mathrm{BrO}$ number densities, weighted with the appropriate $\mathrm{AMF}_{\mathrm{b}}$. Finally, these ASCDs are converted to adapted vertical column densities
(AVCDs) by dividing them with geometric AMFs $\left(\mathrm{AMF}_{\mathrm{g}}\right)$ :

$[\mathrm{BrO} A V C D]=\frac{\int n_{\mathrm{BrO}}(z) \mathrm{AMF}_{\mathrm{b}}\left(z, \alpha, \theta_{\mathrm{s}}\right) d z}{\operatorname{AMF}_{\mathrm{g}}\left(\theta_{\mathrm{v}}, \theta_{\mathrm{s}}\right)}$

where $n_{\mathrm{BrO}}$ is a vertical profile of simulated $\mathrm{BrO}$ number densities in molecule $\mathrm{cm}^{-3}$ and $\mathrm{AMF}_{\mathrm{g}}$ is given by

$\operatorname{AMF}_{\mathrm{g}}\left(\theta_{\mathrm{v}}, \theta_{\mathrm{s}}\right)=\frac{1}{\cos \left(\theta_{\mathrm{v}}\right)}+\frac{1}{\cos \left(\theta_{\mathrm{s}}\right)}$

with $\theta_{\mathrm{v}}=0^{\circ}$ assumed again. This $\mathrm{AMF}_{\mathrm{g}}$ approximates column-integrated AMFs for a purely stratospheric $\mathrm{BrO}$ profile used for the GOME-SLIMCAT tropospheric BrO VCD dataset within $15 \%$ for $\theta_{\mathrm{s}} \leq 80^{\circ}$.

Supplement related to this article is available online at:
http://www.atmos-chem-phys.net/11/3949/2011/
acp-11-3949-2011-supplement.pdf.

Acknowledgements. We thank A. Hussain and M. Neish for their assistance with computer programing for GEM-AQ, E. Chan of Environment Canada for providing surface ozone data from Alert, A. Platt of Environment Canada for the maintenance of meteorological equipments at Alert GAW station, and A.G. Hjellbrekke of Norwegian Institute for Air Research for providing meteorological data from Zeppelin. Surface ozone data for Barrow and Summit were obtained from NOAA/ESRL Global Monitoring Division (http://www.esrl.noaa.gov/gmd/) and for Zeppelin from the EMEP Chemical Coordinating Centre at Norwegian Institute of Air Research (http://tarantula.nilu.no/projects/ccc/emepdata.html). Ozonesonde data were obtained from World Ozone and Ultraviolet Radiation Data Centre (http://exp-studies.tor.ec.gc.ca/e/WOUDC.htm). We also thank M. Samaali and J. Racine of the Canadian Meteorological Centre for assistance with back-trajectory analysis. KT is indebted to L. Kaleschke, T. L. Zhao, H. K. Roscoe, A. Dastoor, D. Durnford, T. Kikuchi, J. Inoue, J. Zhang and B. Johnson for useful comments and discussion. This study was supported by Canadian Foundation for Climate and Atmospheric Sciences, Ontario Ministry of the Environment, Canada Foundation for Innovation, Ontario Innovation Trust, and Natural Sciences and Engineering Research Council of Canada. Analysis of the GOME $\mathrm{BrO}$ data was funded by the University of Bremen and the European Union THALOZ project. The SLIMCAT modeling work at Leads was supported by the UK NCEO.

Edited by: J. W. Bottenheim

\section{References}

Abbatt, J.: Interactions of atmospheric trace gases with ice surfaces: Adsorption and reaction, Chem. Rev., 103, 4783-4800, 2003.

Abbatt, J., Oldridge, N., Symington, A., Chukalovskiy, V., McWhinney, R. D., Sjostedt, S., and Cox, R. A.: Release of gasphase halogens by photolytic generation of $\mathrm{OH}$ in frozen halidenitrate solutions: An active halogen formation mechanism?, J. Phys. Chem. A, 114, 6527-6533, 2010. 
Adams, J. W., Holmes, N. S., and Crowley, J. N.: Uptake and reaction of $\mathrm{HOBr}$ on frozen and dry $\mathrm{NaCl} / \mathrm{NaBr}$ surfaces between 253 and 233 K, Atmos. Chem. Phys., 2, 79-91, doi:10.5194/acp2-79-2002, 2002.

Albert, M. R., Grannas, A. M., Bottenheim, J., Shepson, P. B., and Perron, F. E.: Processes and properties of snow-air transfer in the high Arctic with application to interstitial ozone at Alert, Canada, Atmos. Environ., 36, 2779-2787, 2002.

Anastasio, C. and Jordan, A. L.: Photoformation of hydroxyl radical and hydrogen peroxide in aerosol particles from Alert, Nunavut: implications for aerosoland snowpack chemistry in the Arctic, Atmos. Environ., 38, 1153-1166, 2004.

Anastasio, C. and Mozurkewich, M.: Laboratory studies of bromide oxidation in the presence of ozone: Evidence for a glass-surface mediated reaction, J. Atmos. Chem., 41, 135-162, 2002.

Anastasio, C., Galbavy, E. S., Hutterli, M. A., Burkhart, J. F., and Friel, D. K.: Photoformation of hydroxyl radical on snow grains at Summit, Greenland, Atmos. Environ., 41, 5110-5121, 2007.

Anlauf, K. G., Mickle, R. E., and Trivett, N. B. A.: Measurement of ozone during Polar Sunrise Experiment 1992, J. Geophys. Res., 99, 25345-25353, 1994.

Ariya, P. A., Hopper, J. F., and Harris, G. W.: $\mathrm{C}_{2}-\mathrm{C}_{7}$ hydrocarbon concentrations in Arctic snowpack interstitial air: Potential presence of active $\mathrm{Br}$ within the snowpack, J. Atmos. Chem., 34, 55-64, 1999.

Atkinson, R., Baulch, D. L., Cox, R. A., Crowley, J. N., Hampson, R. F., Hynes, R. G., Jenkin, M. E., Rossi, M. J., Troe, J., and IUPAC Subcommittee: Evaluated kinetic and photochemical data for atmospheric chemistry: Volume II - gas phase reactions of organic species, Atmos. Chem. Phys., 6, 3625-4055, doi:10.5194/acp-6-3625-2006, 2006.

Atkinson, R., Baulch, D. L., Cox, R. A., Crowley, J. N., Hampson, R. F., Hynes, R. G., Jenkin, M. E., Rossi, M. J., and Troe, J.: Evaluated kinetic and photochemical data for atmospheric chemistry: Volume III - gas phase reactions of inorganic halogens, Atmos. Chem. Phys., 7, 981-1191, doi:10.5194/acp-7-981-2007, 2007.

Barrie, L. A., Bottenheim, J. W., Schnell, R. C., Crutzen, P. J., and Rasmussen, R. A.: Ozone destruction and photochemical reactions at polar sunrise in the lower Arctic troposphere, Nature, 334, 138-141, 1988.

Barrie, L. A., Li, S.-M., Toom, D. L., Landsberger, S., and Sturges, W.: Lower tropospheric measurements of halogens, nitrates, and sulphur oxides during Polar Sunrise Experiment 1992, J. Geophys. Res., 99, 25453-25467, 1994.

Bartlett, W. P. and Margerum, D. W.: Temperature dependencies of the Henry's law constant and the aqueous phase dissociation constant of bromine chloride, Environ. Sci. Technol., 33, 34103414, 1999.

Begoin, M., Richter, A., Weber, M., Kaleschke, L., Tian-Kunze, X., Stohl, A., Theys, N., and Burrows, J. P.: Satellite observations of long range transport of a large BrO plume in the Arctic, Atmos. Chem. Phys., 10, 6515-6526, doi:10.5194/acp-10-65152010, 2010.

Berg, W., Sperry, P., Rahn, K., and Gladney, E.: Atmospheric bromine in the Arctic, J. Geophys. Res., 88(C11), 6719-6736, 1983.

Bottenheim, J. W. and Chan, E.: A trajectory study into the origin of spring time Arctic boundary layer ozone depletion, J. Geophys.
Res., 111, D19301, doi:10.1029/2006JD007055, 2006.

Bottenheim, J. W., Gallant, A. G., and Brice, K. A.: Measurements of $\mathrm{NO}_{\mathrm{y}}$ species and $\mathrm{O}_{3}$ at $82^{\circ} \mathrm{N}$ latitude, Geophys. Res. Lett., 13, 113-116, 1986.

Bottenheim, J. W., Barrie, L. A., Atlas, E., Heidt, L. E., Niki, H., Rasmussen, R. A., and Shepson, P. B.: Depletion of lower tropospheric ozone during Arctic spring: The Polar Sunrise Experiment 1988, J. Geophys. Res., 95, 18555-18568, 1990.

Bottenheim, J. W., Fuentes, J. D., Tarasick, D. W., and Anlauf, K. G.: Ozone in the Arctic lower troposphere during winter and spring 2000 (ALERT2000), Atmos. Environ., 36, 2535-2544, 2002.

Bottenheim, J. W., Netcheva, S., Morin, S., and Nghiem, S. V.: Ozone in the boundary layer air over the Arctic Ocean: measurements during the TARA transpolar drift 2006-2008, Atmos. Chem. Phys., 9, 4545-4557, doi:10.5194/acp-9-4545-2009, 2009.

Brimblecombe, P. and Clegg, S. L.: The solubility and behaviour of acid gases in the marine aerosol, J. Atmos. Chem., 7, 1-18, 1988.

Brimblecombe, P. and Clegg, S. L.: Erratum, 8, p. 95, 1989.

Chance, K.: Analysis of BrO measurements from the Global Ozone Monitoring Experiment, Geophys. Res. Lett., 25, 3335-3338, 1998.

Chipperfield, M. P.: Multiannual simulations with a threedimensional chemical transport model, J. Geophys. Res., 104, 1781-1805, 1999.

Chipperfield, M. P.: New version of the TOMCAT/SLIMCAT offline chemical transport model: Intercomparison of stratospheric tracer experiments, Q. J. Roy. Meteorol. Soc., 132, 1179-1203, 2006.

Chipperfield, M. P., Feng, W., and Rex, M.: Arctic ozone loss and climate sensitivity: Updated three-dimensional model study, Geophys. Res. Lett., 32, L11813, doi:10.1029/2005GL022674, 2005.

Cho, H., Shepson, P. B., Barrie, L. A., Cowin, J. P., and Zaveri, R.: NMR investigation of the quasi-brine layer in ice/brine mixtures, J. Phys. Chem. B, 106, 11226-11232, 2002.

Christensen, J. H.: The Danish Eulerian hemispheric model - A three-dimensional air pollution model used for the Arctic, Atmos. Environ., 31, 4169-4191, 1997.

Chu, L. and Anastasio, C.: Quantum yields of hydroxyl radical and nitrogen dioxide from the photolysis of nitrate on ice, J. Phys. Chem. A, 107, 9594-9602, 2003.

Chu, L. and Anastasio, C.: Formation of hydroxyl radical from the photolysis of frozen hydrogen peroxide, J. Phys. Chem. A, 109, 6264-6271, 2005.

Côté, J., Gravel, S., Méhot, A., Patoine, A., Roch, M., and Staniforth, A.: The Operational CMC.MRB Global Environmental Multiscale (GEM) Model, Part I: Design Considerations and Formulation, Mon. Weather Rev., 126, 1373-1395, 1998.

Cunningham, J. and Waddington, E. D.: Air flow and dry deposition of non-sea salt sulfate in polar firn: Paleoclimatic implications, Atmos. Environ., 27A, 2943-2956, 1993.

Curry, J.: On the formation of continental polar air, J. Atmos. Sci., 40, 2278-2292, 1983.

DeMore, W. B., Sander, S. P., Golden, D. M., Hampson, R. F., Kurylo, M. J., Howard, C. J., Ravishankara, A. R., Kolb, C. E., and Molina, M. J.: Chemical Kinetics and Photochemical Data 
for Use in Stratospheric Modeling, Evaluation 12, JPL Publication 97-4, Jet Propulsion Laboratory, Pasadena, California, USA, 1997.

Dibb, J. E., Whitlow, S. I., and Arsenault, M.: Seasonal variations in the soluble ion content of snow at Summit. Greenland: Constraints from three years of daily surface snow samples, Atmos. Environ., 41, 5007-5019, 2007.

Dibb, J. E., Ziemba, L. D., Luxford, J., and Beckman, P.: Bromide and other ions in the snow, firn air, and atmospheric boundary layer at Summit during GSHOX, Atmos. Chem. Phys., 10, 99319942, doi:10.5194/acp-10-9931-2010, 2010.

Dieckmann, G. S., Nehrke, G., Uhlig, C., Göttlicher, J., Gerland, S., Granskog, M. A., and Thomas, D. N.: Brief Communication: Ikaite $\left(\mathrm{CaCO}_{3} \cdot 6 \mathrm{H}_{2} \mathrm{O}\right)$ discovered in Arctic sea ice, The Cryosphere, 4, 227-230, doi:10.5194/tc-4-227-2010, 2010.

Douglas, T. A. and Sturm, M.: Arctic haze, mercury and the chemical composition of snow across northwestern Alaska, Atmos. Environ., 38, 805-820, 2004.

Drobot, S. D. and Anderson, M. R.: Comparison of interannual snowmelt-onset dates with atmospheric conditions, Ann. Glaciol., 33, 79-84, 2001a.

Drobot, S. D. and Anderson, M. R.: An improved method for determining snowmelt onset dates over Arctic sea ice using scanning multichannel microwave radiometer and Special Sensor Microwave/Imager data, J. Geophys. Res., 106, 24033-24049, $2001 b$.

Dvortsov, V. L., Geller, M. A., Solomon, S., Schauffler, S. M., Atlas, E. L., and Blake, D. R.: Rethinking reactive halogen budgets in the midlatitude lower stratosphere, Geophys. Res. Lett., 26(12), 1699-1702, 1999.

Eicken, H., Krouse, H. R., Kadko, D., and Perovich, D. K.: Tracer studies of pathways and rates of meltwater transport through Arctic summer sea ice, J. Geophys. Res., 107(C10), 8046, doi:10.1029/2000JC000583, 2002.

Enami, S., Vecitis, C. D., Cheng, J., Hoffmann, M. R., and Colussi, A. J.: Global inorganic source of atmospheric bromine, J. Phys. Chem. A, 111, 8749-8752, 2007.

Fan, S.-M. and Jacob, D. J.: Surface ozone depletion in Arctic spring sustained by bromine reactions on aerosols, Nature, 359, 522-524, 1992.

Feng, W., Chipperfield, M. P., Dorf, M., Pfeilsticker, K., and Ricaud, P.: Mid-latitude ozone changes: studies with a 3-D CTM forced by ERA-40 analyses, Atmos. Chem. Phys., 7, 2357-2369, doi:10.5194/acp-7-2357-2007, 2007.

Fett, R. W., Burk, S. D., Thompson, W. T., and Kozo, T. L.: Environmental phenomena of the Beaufort Sea observed during the Leads Experiment, B. Am. Meteorol. Soc., 75, 2131-2145, 1994.

Fickert, S., Adams, J. W., and Crowley, J. N.: Activation of $\mathrm{Br}_{2}$ and $\mathrm{BrCl}$ via uptake of $\mathrm{HOBr}$ onto aqueous salt solutions, J. Geophys. Res., 104, 23719-23727, 1999.

Fitzenberger, R., Bosch, H., Camy-Peyret, C., Chipperfield, M. P., Harder, H., Platt, U., Sinnhuber, B.-M., Wagner, T., and Pfeilsticker, K.: First profile measurements of tropospheric BrO, Geophys. Res. Lett., 27, 2921-2924, 2000.

Foster, K. L., Plastridge, R. A., Bottenheim, J. W., Shepson, P. B., Finlayson-Pitts, B. J., and Spicer, C. W.: The role of $\mathrm{Br}_{2}$ and $\mathrm{BrCl}$ in surface ozone destruction at polar sunrise, Science, 291, 471-474, 2001.

Frenzel, A., Scheer, V., Sikorski, R., George, C., Behnke, W., and
Zetzsch, C.: Heterogeneous interconversion reactions of $\mathrm{BrNO}_{2}$, $\mathrm{ClNO}_{2}, \mathrm{Br}_{2}$, and $\mathrm{Cl}_{2}$, J. Phys. Chem. A, 102, 1329-1337, 1998.

Frieß, U., Wagner, T., Pundt, I., Pfeilsticker, K., and Platt, U.: Spectroscopic measurements of tropospheric iodine oxide at Neumayer Station, Antarctica, Geophys. Res. Lett., 28, 1941-1944, 2001.

Frieß, U., Hollwedel, J., Koönig-Langlo, G., Wagner, T., and Platt, U.: Dynamics and chemistry of tropospheric bromine explosion events in the Antarctic coastal region, J. Geophys. Res., 109, D06305, doi:10.1029/2003JD004133, 2004.

Gauthier, P., Charette, C., Fillion, L., Koclas, P., and Laroche, S.: Implementation of a 3-D assimilation system at the Canadian Meteorological Centre, Part I: The global analysis, Atmos.Ocean, 37, 103-156, 1999.

Gjessing, Y. T.: Episodic variations of snow contamination of an Arctic snowfield, Atmos. Environ., 11, 643-647, 1977.

Gong, S. L., Walmsley, J. L., Barrie, L. A., and Hopper, J. F.: Mechanisms for surface ozone depletion and recovery during polar sunrise, Atmos. Environ., 31, 969-981, 1997.

Gong, S. L., Barrie, L. A., Blanchet, J. P., von Salzen, K., Lohmann, U., Lesins, G., Spacek, L., Zhang, L. M., Girard, E., Lin, H., Leaitch, R., Leighton, H., Chylek, P., and Huang, P.: Canadian Aerosol Module: A size-segregated simulation of atmospheric aerosol processes for climate and air quality models 1, Module development, J. Geophys. Res., 108(D1), 4007, doi:10.1029/2001JD002002, 2003.

Grannas, A. M., Jones, A. E., Dibb, J., Ammann, M., Anastasio, C., Beine, H. J., Bergin, M., Bottenheim, J., Boxe, C. S., Carver, G., Chen, G., Crawford, J. H., Dominé, F., Frey, M. M., Guzmán, M. I., Heard, D. E., Helmig, D., Hoffmann, M. R., Honrath, R. E., Huey, L. G., Hutterli, M., Jacobi, H. W., Klán, P., Lefer, B., McConnell, J., Plane, J., Sander, R., Savarino, J., Shepson, P. B., Simpson, W. R., Sodeau, J. R., von Glasow, R., Weller, R., Wolff, E. W., and Zhu, T.: An overview of snow photochemistry: evidence, mechanisms and impacts, Atmos. Chem. Phys., 7, 4329-4373, doi:10.5194/acp-7-4329-2007, 2007.

Hausmann, M. and Platt, U.: Spectroscopic measurement of bromine oxide and ozone in the high Arctic during Polar Sunrise Experiment 1992, J. Geophys. Res., 99, 25399-25413, 1994.

Helmig, D., Boulter, J., David, D., Birks, J. W., Cullen, N. J., Steffen, K., Johnson, B. J., and Oltmans, S. J.: Ozone and meteorological boundary-layer conditions at Summit, Greenland, during 3-21 June 2000, Atmos. Environ., 36, 2595-2608, 2002.

Helmig, D., Bocquet, F., Cohen, L., and Oltmans, S. J.: Ozone uptake to the polar snowpack at Summit, Greenland, Atmos. Environ., 41, 5061-5076, 2007a.

Helmig, D., Ganzeveld, L., Butler, T., and Oltmans, S. J.: The role of ozone atmosphere-snow gas exchange on polar, boundarylayer tropospheric ozone - a review and sensitivity analysis, Atmos. Chem. Phys., 7, 15-30, doi:10.5194/acp-7-15-2007, $2007 \mathrm{~b}$.

Hendrick, F., Van Roozendael, M., Chipperfield, M. P., Dorf, M., Goutail, F., Yang, X., Fayt, C., Hermans, C., Pfeilsticker, K., Pommereau, J.-P., Pyle, J. A., Theys, N., and De Mazière, M.: Retrieval of stratospheric and tropospheric BrO profiles and columns using ground-based zenith-sky DOAS observations at Harestua, $60^{\circ} \mathrm{N}$, Atmos. Chem. Phys., 7, 4869-4885, doi:10.5194/acp-7-4869-2007, 2007.

Holt, B. and Digby, S. A.: Processes and Imagery of First-Year Fast Sea Ice During the Melt Season, J. Geophys. Res., 90, 5045- 
$5062,1985$.

Hopper, J. F. and Hart, W.: Meteorological aspects of the 1992 Polar Sunrise Experiment, J. Geophys. Res., 99, 25315-25328, 1994.

Hopper, J. F., Barrie, L. A., Silis, A., Hart, W., Gallant, A. J., and Dryfhout, H.: Ozone and meteorology during the 1994 Polar Sunrise Experiment, J. Geophys. Res., 103, 1481-1492, 1998.

Hossaini, R., Chipperfield, M. P., Monge-Sanz, B. M., Richards, N. A. D., Atlas, E., and Blake, D. R.: Bromoform and dibromomethane in the tropics: A 3D model study of chemistry and transport, Atmos. Chem. Phys., 10, 719-735, doi:10.5194/acp10-719-2010, 2010.

Huff, A. K. and Abbatt, J. P. D.: Kinetics and product yields in the heterogeneous reactions of $\mathrm{HOBr}$ with ice surfaces containing $\mathrm{NaBr}$ and $\mathrm{NaCl}$, J. Phys. Chem. A, 106(21), 5279-5287, 2002.

Impey, G. A., Shepson, P. B., Barrie, L. A., and Anlauf, K. G.: Measurements of photolyzable chlorine and bromine during the Polar Sunrise Experiment 1995, J. Geophys. Res., 102, 1600516010, 1997.

IUPAC: IUPAC Subcommittee on Gas Kinetic Data Evaluation, Data Sheet oBrOx15, 3rd July 2005, http://www.iupac-kinetic. ch.cam.ac.uk/, 2005.

Jacobi, H.-W., Morin, S., and Bottenheim, J. W.: Observation of widespread depletion of ozone in the springtime boundary layer of the central Arctic linked to mesoscale synoptic conditions, J. Geophys. Res., 115, D17302, doi:10.1029/2010JD013940, 2010.

Jobson, B. T., Niki, H., Yokouchi, Y., Bottenheim, J., Hopper, F., and Leaitch, R.: Measurements of $\mathrm{C}_{2}-\mathrm{C}_{6}$ hydrocarbons during the Polar Sunrise 1992 Experiment: Evidence for $\mathrm{Cl}$ atom and Br atom chemistry, J. Geophys. Res., 99, 25355-25368, 1994.

Jöckel, P., Tost, H., Pozzer, A., Brühl, C., Buchholz, J., Ganzeveld, L., Hoor, P., Kerkweg, A., Lawrence, M. G., Sander, R., Steil, B., Stiller, G., Tanarhte, M., Taraborrelli, D., van Aardenne, J., and Lelieveld, J.: The atmospheric chemistry general circulation model ECHAM5/MESSy1: consistent simulation of ozone from the surface to the mesosphere, Atmos. Chem. Phys., 6, 50675104, doi:10.5194/acp-6-5067-2006, 2006.

Jones, A. E., Anderson, P. S., Begoin, M., Brough, N., Hutterli, M. A., Marshall, G. J., Richter, A., Roscoe, H. K., and Wolff, E. W.: $\mathrm{BrO}$, blizzards, and drivers of polar tropospheric ozone depletion events, Atmos. Chem. Phys., 9, 4639-4652, doi:10.5194/acp-94639-2009, 2009.

Jones, A. E., Anderson, P. S., Wolff, E. W., Roscoe, H. K., Marshall, G. J., Richter, A., Brough, N., and Colwell, S. R.: Vertical structure of Antarctic tropospheric ozone depletion events: characteristics and broader implications, Atmos. Chem. Phys., 10, 7775-7794, doi:10.5194/acp-10-7775-2010, 2010.

Kaleschke, L., Richter, A., Burrows, J., Afe, O., Heygster, G., Notholt, J., Rankin, A. M., Roscoe, H. K., Hollwedel, J., Wagner, T., and Jacobi, H. W.: Frost flowers on sea ice as a source of sea salt and their influence on tropospheric halogen chemistry, Geophys. Res. Lett., 31, L16114, doi:10.1029/2004GL020655, 2004.

Kaminski, J. W., Neary, L., Struzewska, J., McConnell, J. C., Lupu, A., Jarosz, J., Toyota, K., Gong, S. L., Côté, J., Liu, X., Chance, K., and Richter, A.: GEM-AQ, an on-line global multiscale chemical weather modelling system: model description and evaluation of gas phase chemistry processes, Atmos. Chem. Phys., 8, 3255-3281, doi:10.5194/acp-8-3255-2008, 2008.

Kirchner, U., Benter, T. H., and Schindler, R. N.: Experimental ver- ification of gas phase bromine enrichment in reactions of $\mathrm{HOBr}$ with sea salt doped ice surfaces, Ber. Bunsenges. Phys. Chem., 101, 975-977, 1997.

Knepp, T. N., Bottenheim, J., Carlsen, M., Carlson, D., Donohoue, D., Friederich, G., Matrai, P. A., Netcheva, S., Perovich, D. K., Santini, R., Shepson, P. B., Simpson, W., Valentic, T., Williams, C., and Wyss, P. J.: Development of an autonomous sea ice tethered buoy for the study of ocean-atmosphere-sea ice-snow pack interactions: the O-buoy, Atmos. Meas. Tech., 3, 249-261, doi:10.5194/amt-3-249-2010, 2010.

Koop, T., Kapilashrami, A., Molina, L. T., and Molina, M. J.: Phase transitions of sea-salt/water mixtures at low temperatures: Implications for ozone chemistry in the polar marine boundary layer, J. Geophys. Res., 105, 26393-26402, 2000.

Kreher, K., Johnston, P. V., Wood, S. W., Nardi, B., and Platt, U.: Ground-based measurements of tropospheric and stratospheric $\mathrm{BrO}$ at Arrival Heights, Antarctica, Geophys. Res. Lett., 24, 3021-3024, 1997.

Kwok, R.: Annual cycles of multiyear sea ice coverage of the Arctic Ocean: 1999-2003, J. Geophys. Res., 109, C11004, doi:10.1029/2004JC002238, 2004.

Kwok, R.: Contrasts in sea ice deformation and production in the Arctic seasonal and perennial ice zones, J. Geophys. Res., 111, C11S22, doi:10.1029/2005JC003246, 2006.

Kwok, R., Cunningham, G. F., and Yueh, S.: Area balance of the Arctic Ocean perennial ice zone: October 1996 to April 1997, J. Geophys. Res., 104, 25747-25759, 1999.

Langner, J., Robertson, L., Persson, C., and Ullerstig, A.: Validation of the operational emergency response model at the Swedish Meteorological and Hydrological Institute using data from etex and the chernobyl accident, Atmos. Environ., 32, 4325-4333, 1998.

Lax, E.: Taschenbuch für Chemiker und Physiker, Springer Verlag, Berlin, 1969.

Lehrer, E., Wagenbach, D., and Platt, U.: Aerosol chemical composition during tropospheric ozone depletion at $\mathrm{Ny}$ Ålesund/Svalbard, Tellus, 49B, 486-495, 1997.

Lehrer, E., Hönninger, G., and Platt, U.: A one dimensional model study of the mechanism of halogen liberation and vertical transport in the polar troposphere, Atmos. Chem. Phys., 4, 2427 2440, doi:10.5194/acp-4-2427-2004, 2004.

Li, S.-M., Yokouchi, Y., Barrie, L. A., Muthuramu, K., Shepson, P. B., Bottenheim, J. W., Sturges, W. T., and Landsberger, S.: Organic and inorganic bromine compounds and their composition in the Arctic troposphere during polar sunrise, J. Geophys. Res., 99, 25415-25428, 1994.

Liang, Q., Stolarski, R. S., Kawa, S. R., Nielsen, J. E., Douglass, A. R., Rodriguez, J. M., Blake, D. R., Atlas, E. L., and Ott, L. E.: Finding the missing stratospheric Bry: a global modeling study of $\mathrm{CHBr}_{3}$ and $\mathrm{CH}_{2} \mathrm{Br}_{2}$, Atmos. Chem. Phys., 10, 2269-2286, doi:10.5194/acp-10-2269-2010, 2010.

Light, B., Maykut, G. A., and Grenfell, T. C.: Effects of temperature on the microstructure of first-year Arctic sea ice, J. Geophys. Res., 108(C2), 3051, doi:10.1029/2001JC000887, 2003.

Lupu, A., Kaminski, J. W., Neary, L., McConnell, J. C., Toyota, K., Rinsland, C. P., Bernath, P. F., Walker, K. A., Boone, C. D., Nagahama, Y., and Suzuki, K.: Hydrogen cyanide in the upper troposphere: GEM-AQ simulation and comparison with ACE-FTS observations, Atmos. Chem. Phys., 9, 4301-4313, doi:10.5194/acp-9-4301-2009, 2009. 
Mahajan, A. S., Shaw, M., Oetjen, H., Hornsby, K. E., Carpenter, L. J., Kaleschke, L., TianKunze, X., Lee, J. D., Moller, S. J., Edwards, P., Commane, R., Ingham, T., Heard, D. E., and Plane, J. M. C.: Evidence of reactive iodine chemistry in the Arctic boundary layer, J. Geophys. Res., 115, D20303, doi:10.1029/2009JD013665, 2010.

Martin, S., Yu, Y., and Drucker, R.: The temperature dependence of frost flower growth on laboratory sea ice and the effect of the flowers on infrared observations of the surface, J. Geophys. Res., 101(C5), 12111-12125, 1996.

McConnell, J. C., Henderson, G. S., Barrie, L., Bottenheim, J., Niki, H., Langford, C. H., and Templeton, E. M. J.: Photochemical bromine production implicated in Arctic boundary-layer ozone depletion, Nature, 355, 150-152, 1992.

McElroy, C. T., McLinden, C. A., and McConnell, J. C.: Evidence for bromine monoxide in the free troposphere during the Arctic polar sunrise, Nature, 397, 338-341, 1999.

McLinden, C. A., Olsen, S., Hannegan, B., Wild, O., Prather, M. J., and Sundet, J.: Stratospheric ozone in 3-D models: A simple chemistry and the cross-tropopause flux, J. Geophys. Res., 105, 14653-14665, 2000.

McLinden, C. A., McConnell, J. C., Griffioen, E., and McElroy, C. T.: A vector radiative transfer model for the Odin/OSIRIS project, Can. J. Phys., 80, 375-393, 2002.

McLinden, C. A., Haley, C. S., and Sioris, C. E.: Diurnal effects in limb scatter observations, J. Geophys. Res., 111, D14302, doi:10.1029/2005JD006628, 2006.

McLinden, C. A., Haley, C. S., Lloyd, N., Hendrick, F., Rozanov, A., Sinnhuber, B.-M., Goutail, F., Degenstein, D., Llewellyn, E., Sioris, C. E., Roozendael, M. V., Pommereau, J. P., Lotz, W., and Burrows, J. P.: Odin and OSIRIS observations of stratospheric BrO: Retrieval methodology, climatology, and inferred Bry, J. Geophys. Res., 115, D15308, doi:10.1029/2009JD012488, 2010.

Michalowski, B. A., Francisco, J. S., Li, S. M., Barrie, L. A., Bottenheim, J. W., and Shepson, P. B.: A computer model study of multiphase chemistry in the Arctic boundary layer during polar sunrise, J. Geophys. Res., 105, 15131-15145, 2000.

Millero, F. J., Feistel, R., Wright, D. G., and McDougall, T. J.: The composition of Standard Seawater and the definition of the Reference-Composition Salinity Scale, Deep-Sea Res. I, 55, 5072, 2008.

Monge-Sanz, B., Chipperfield, M. P., Simmons, A., and Uppala, S.: Mean age of air and transport in a CTM: Comparison of different ECMWF analyses, Geophys. Res. Lett., 34, L04801, doi:10.1029/2006GL028515, 2007.

Morin, S., Hönninger, G., Staebler, R. M., and Bottenheim, J. W.: A high time resolution study of boundary layer ozone chemistry and dynamics over the Arctic Ocean near Alert, Nunavut, Geophys. Res. Lett., 32, L08809, doi:10.1029/2004GL022098, 2005.

Morin, S., Marion, G. M., von Glasow, R., Voisin, D., Bouchez, J., and Savarino, J.: Precipitation of salts in freezing seawater and ozone depletion events: a status report, Atmos. Chem. Phys., 8, 7317-7324, doi:10.5194/acp-8-7317-2008, 2008.

Mozurkewich, M.: Mechanisms for the release of halogens from sea-salt particles by free radical reactions, J. Geophys. Res., 100, 14199-14207, 1995.

Murayama, S., Nakazawa, T., Tanaka, M., Aoki, S., and Kawaguchi, S.: Variations in tropospheric ozone concentration over Syowa Station, Antarctica, Tellus, 44B, 262-272, 1992.
Oldridge, N. W. and Abbatt, J. P. D.: Formation of gas-phase bromine from interaction of ozone with frozen and liquid $\mathrm{NaCl} / \mathrm{NaBr}$ solutions: Quantitative separation of surficial chemistry from bulk-phase reaction, J. Phys. Chem. A, 115, 25902598, doi:10.1021/jp200074u, 2011.

Oltmans, S. J.: Surface ozone measurements in clean air, J. Geophys. Res., 86, 1174-1180, 1981.

Oltmans, S. J., Schnell, R. C., Sheridan, P. J., Peterson, R. E., Li, S.-M., Winchester, J. W., Tans, P. P., Sturges, W. T., Kahl, J. D., and Barrie, L. A.: Seasonal surface ozone and filterable bromine relationship in the high Arctic, Atmos. Environ., 23, 2431-2441, 1989.

O’Neill, N. T., Campanelli, M., Lupu, A., Thulasiraman, S., Reid, J. S., Aubé, M., Neary, L., Kaminski, J. W., and McConnell, J. C.: Evaluation of the GEM-AQ air quality model during the Québec smoke event of 2002: Analysis of extensive and intensive optical disparities, Atmos. Environ., 40, 3737-3749, 2006.

Oum, K. W., Lakin, M. J., and Finlayson-Pitts, B. J.: Bromine activation in the troposphere by the dark reaction of $\mathrm{O}_{3}$ with seawater ice, Geophys. Res. Lett., 25, 3923-3926, 1998.

Overland, J. E. and Wang, M.: Future regional Arctic sea ice declines, Geophys. Res. Lett., 34, L17705, doi:10.1029/2007GL030808, 2007.

Perovich, D. K. and Richter-Menge, J. A.: Surface characteristics of lead ice, J. Geophys. Res., 99, 16341-16350, 1994.

Peterson, M. and Honrath, R.: Observations of rapid photochemical destruction of ozone in snowpack interstitial air, Geophys. Res. Lett., 28, 511-514, 2001.

Piot, M. and von Glasow, R.: The potential importance of frost flowers, recycling on snow, and open leads for ozone depletion events, Atmos. Chem. Phys., 8, 2437-2467, doi:10.5194/acp-82437-2008, 2008.

Pöhler, D., Vogel, L., Frieß, U., and Platt, U.: Observation of halogen species in the Amundsen Gulf, Arctic, by active long-path differential optical absorption spectroscopy, Proc. Nat. Acad. Sci., 107, 6582-6587, doi:10.1073/pnas.0912231107, 2010.

Ramacher, B., Rudolph, J., and Koppmann, R.: Hydrocarbon measurements during tropospheric ozone depletion events: Evidence for halogen atom chemistry, J. Geophys. Res., 104, 3633-3653, 1999.

Rankin, A. M., Wolff, E. W., and Martin, S.: Frost flowers: Implications for tropospheric chemistry and ice core interpretation, J. Geophys. Res., 107(D23), 4683, doi:10.1029/2002JD002492, 2002.

Richter, A.: GOME tropospheric BrO columns Version 1, available at: http://www.iup.uni-bremen.de/doas/gome_bro_data.htm, 2006.

Richter, A., Wittrock, F., Eisinger, M., and Burrows, J. P.: GOME observations of tropospheric $\mathrm{BrO}$ in northern hemispheric spring and summer 1997, Geophys. Res. Lett., 25, 2683-2686, 1998.

Richter, A., Wittrock, F., Ladstätter-Weißenmayer, A., and Burrows, J.: GOME measurements of stratospheric and tropospheric BrO, Adv. Space Res., 29, 1667-1672, 2002.

Richter-Menge, J. A. and Jones, K. F.: The tensible strength of firstyear sea ice, J. Glaciol., 39, 609-618, 1993.

Sadanaga, Y., Hirokawa, J., and Akimoto, H.: Formation of molecular chlorine in dark condition: Heterogeneous reaction of ozone with sea salt in the presence of ferric ion, Geophys. Res. Lett., 28, 4433-4436, 2001. 
Saiz-Lopez, A., Mahajan, A. S., Salmon, R. A., Bauguitte, S. J.-B., Jones, A. E., Roscoe, H. K., and Plane, J. M. C.: Boundary layer halogens in coastal Antarctica, Science, 317, 348-351, 2007.

Salawitch, R. J., Weisenstein, D. K., Kovalenko, L. J., Sioris, C. E., Wennberg, P. O., Chance, K., Ko, M. K. W., and McLinden, C. A.: Sensitivity of ozone to bromine in the lower stratosphere, Geophys. Res. Lett., 32, L05811, doi:10.1029/2004GL021504, 2005.

Salawitch, R. J., Canty, T., Kurosu, T., Chance, K., Liang, Q., da Silva, A., Pawson, S., Nielsen, J. E., Rodriguez, J., Bhartia, P., Liu, X., Huey, L., Liao, J., Stickel, R., Simpson, W., Donohoue, D., Weinheimer, A., Flocke, F., Knapp, D., Montzka, D., Neuman, J., Nowak, J., Ryerson, T., Oltmans, S., Blake, D., Atlas, E. L., Kinnison, D., Tilmes, S., Pan, L., Hendrick, F., Roozendael, M. V., Kreher, K., Johnston, P., Gao, R. S., Johnson, B., Bui, T., Chen, G., Pierce, R. B., Crawford, J. H., and Jacob, D. J.: A New Interpretation of Total Column BrO during Arctic Spring, Geophys. Res. Lett., 37, L21805, doi:10.1029/2010GL043798, 2010.

Sammonds, P. R., Murrell, S. A. F., and Rist, M. A.: Fracture of multiyear sea ice, J. Geophys. Res., 103, 21795-21815, 1998.

Sander, R. and Morin, S.: Introducing the bromide/alkalinity ratio for a follow-up discussion on "Precipitation of salts in freezing seawater and ozone depletion events: a status report", by Morin et al., published in Atmos. Chem. Phys., 8, 7317-7324, 2008, Atmos. Chem. Phys., 10, 7655-7658, doi:10.5194/acp-10-76552010, 2010.

Sander, R., Kerkweg, A., Jöckel, P., and Lelieveld, J.: Technical note: The new comprehensive atmospheric chemistry module MECCA, Atmos. Chem. Phys., 5, 445-450, doi:10.5194/acp-5445-2005, 2005.

Sander, R., Burrows, J., and Kaleschke, L.: Carbonate precipitation in brine - a potential trigger for tropospheric ozone depletion events, Atmos. Chem. Phys., 6, 4653-4658, doi:10.5194/acp-64653-2006, 2006.

Schoeberl, M. R., Douglass, A. R., Zhu, Z., and Pawson, S.: A comparison of the lower stratospheric age spectra derived from a general circulation model and two data assimilation systems, J. Geophys. Res., 108(D3), 4113, doi:10.1029/2002JD002652, 2003.

Schönhardt, A., Richter, A., Wittrock, F., Kirk, H., Oetjen, H., Roscoe, H. K., and Burrows, J. P.: Observations of iodine monoxide columns from satellite, Atmos. Chem. Phys., 8, 637653, doi:10.5194/acp-8-637-2008, 2008.

Semb, A., Brækkan, R., and Joranger, E.: Major ions in Spitsbergen snow samples, Geophys. Res. Lett., 11, 445-448, 1984.

Shupe, M. D., Matrosov, S. Y., and Uttal, T.: Arctic mixed-phase cloud properties derived from surface-based sensors at SHEBA, J. Atmos. Sci., 63, 697-711, 2006.

Simpson, W. R., Alvarez-Aviles, L., Douglas, T. A., Sturm, M., and Domine, F.: Halogens in the coastal snow pack near Barrow, Alaska: Evidence for active bromine air-snow chemistry during springtime, Geophys. Res. Lett., 32, L04811, doi:10.1029/2004GL021748, 2005.

Simpson, W. R., Carlson, D., Hönninger, G., Douglas, T. A., Sturm, M., Perovich, D., and Platt, U.: First-year sea-ice contact predicts bromine monoxide $(\mathrm{BrO})$ levels at Barrow, Alaska better than potential frost flower contact, Atmos. Chem. Phys., 7, 621-627, doi:10.5194/acp-7-621-2007, 2007a.
Simpson, W. R., von Glasow, R., Riedel, K., Anderson, P., Ariya, P., Bottenheim, J., Burrows, J., Carpenter, L., Frieß, U., Goodsite, M. E., Heard, D., Hutterli, M., Jacobi, H.-W., Kaleschke, L., Neff, B., Plane, J., Platt, U., Richter, A., Roscoe, H., Sander, R., Shepson, P., Sodeau, J., Steffen, A., Wagner, T., and Wolff, E.: Halogens and their role in polar boundary-layer ozone depletion, Atmos. Chem. Phys., 7, 4375-4418, 2007b.

Sioris, C. E., Kovalenko, L. J., McLinden, C. A., Salawitch, R. J., Roozendael, M. V., Goutail, F., Dorf, M., Pfeilsticker, K., Chance, K., von Savigny, C., Liu, X., Kurosu, T. P., Pommereau, J.-P., Bösch, H., and Frerick, J.: Latitudinal and vertical distribution of bromine monoxide in the lower stratosphere from Scanning Imaging Absorption Spectrometer for Atmospheric Chartography limb scattering measurements, J. Geophys. Res., 111, D14301, doi:10.1029/2005JD006479, 2006.

Sjostedt, S. J., Huey, L. G., Tanner, D. J., Peischl, J., Chen, G., Dibb, J. E., Lefer, B., Hutterli, M. A., Beyersdorf, A. J., Blake, N. J., Blake, D. R., Sueper, D., Ryerson, T., Burkhart, J., and Stohl, A.: Observations of hydroxyl and the sum of peroxy radicals at Summit, Greenland during summer 2003, Atmos. Environ., 41, 5122-5137, 2007.

Solberg, S., Schmidbauer, N., Semb, A., Stordal, F., and Hov, O.: Boundary-layer ozone depletion as seen in the Norwegian Arctic in spring, J. Atmos. Chem., 23, 301-332, 1996.

Spicer, C. W., Plastridge, R. A., Foster, K. L., Finlayson-Pitts, B. J., Bottenheim, J. W., Grannas, A. M., and Shepson, P. B.: Molecular halogens before and during ozone depletion events in the Arctic at polar sunrise: concentrations and sources, Atmos. Environ., 36, 2721-2731, 2002.

Steffen, A., Douglas, T., Amyot, M., Ariya, P., Aspmo, K., Berg, T., Bottenheim, J., Brooks, S., Cobbett, F., Dastoor, A., Dommergue, A., Ebinghaus, R., Ferrari, C., Gardfeldt, K., Goodsite, M. E., Lean, D., Poulain, A. J., Scherz, C., Skov, H., Sommar, J., and Temme, C.: A synthesis of atmospheric mercury depletion event chemistry in the atmosphere and snow, Atmos. Chem. Phys., 8, 1445-1482, doi:10.5194/acp-8-1445-2008, 2008.

Steffen, K. and DeMaria, T.: Surface energy fluxes of Arctic winter sea ice in Barrow Strait, J. Appl. Meteorol., 35, 2067-2079, 1996.

Steffen, K., Key, J., Cavalieri, D. J., Comiso, J., Gloersen, P., Germain, K. S., and Rubinstein, I.: The Estimation of Geophysical Parameters Using Passive Microwave Algorithms, in: Microwave Remote Sensing of Sea Ice, edited by: Carsey, F. D., vol. 68, chap. 10, Geophysical Monograph, American Geophysical Union, 1992.

Stockwell, W. R. and Lurmann, F. W.: Intercomparison of the ADOM and RADM Gas-Phase Chemistry Mechanisms, Report prepared for the Electric Power Research Institute, Electric Power Research Institute, Palo Alto, California, USA, 1989.

Stroeve, J., Markus, T., Meier, W. N., and Miller, J.: Recent changes in the Arctic melt season, Ann. Glaciol., 44, 367-374, 2006.

Strong, C., Fuentes, J. D., Davis, R. E., and Bottenheim, J. W.: Thermodynamic attributes of Arctic boundary layer ozone depletion, Atmos. Environ., 36, 2641-2652, 2002.

Struzewska, J. and Kaminski, J. W.: Formation and transport of photooxidants over Europe during the July 2006 heat wave observations and GEM-AQ model simulations, Atmos. Chem. Phys., 8, 721-736, doi:10.5194/acp-8-721-2008, 2008.

Sturges, W. T. and Barrie, L. A.: Chlorine, bromine and iodine in 
arctic aerosols, Atmos. Environ., 22, 1179-1194, 1988.

Tang, T. and McConnell, J. C.: Autocatalytic release of bromine from Arctic snow pack during polar sunrise, Geophys. Res. Lett., 23, 2633-2636, 1996.

Tarasick, D. W. and Bottenheim, J. W.: Surface ozone depletion episodes in the Arctic and Antarctic from historical ozonesonde records, Atmos. Chem. Phys., 2, 197-205, doi:10.5194/acp-2197-2002, 2002.

Theys, N., Van Roozendael, M., Errera, Q., Hendrick, F., Daerden, F., Chabrillat, S., Dorf, M., Pfeilsticker, K., Rozanov, A., Lotz, W., Burrows, J. P., Lambert, J.-C., Goutail, F., Roscoe, H. K., and De Mazière, M.: A global stratospheric bromine monoxide climatology based on the BASCOE chemical transport model, Atmos. Chem. Phys., 9, 831-848, doi:10.5194/acp-9-831-2009, 2009.

Thomas, J. L., Stutz, J., Lefer, B., Huey, L. G., Toyota, K., Dibb, J. E., and von Glasow, R.: Modeling chemistry in and above snow at Summit, Greenland Part 1: Model description and results, Atmos. Chem. Phys. Discuss., 10, 30 927-30970, doi:10.5194/acpd-10-30927-2010, 2010.

Tomasi, C., Vitale, V., Lupi, A., Carmine, C. D., Campanelli, M., Herber, A., Treffeisen, R., Stone, R. S., Andrews, E., Sharma, S., Radionov, V., von Hoyningen-Huene, W., Stebel, K., Hansen, G. H., Myhre, C. L., Wehrli, C., Aaltonen, V., Lihavainen, H., Virkkula, A., Hillamo, R., Ström, J., Toledano, C., Cachorro, V. E., Ortiz, P., de Frutos, A. M., Blindheim, S., Frioud, M., Gausa, M., Zielinski, T., Petelski, T., and Yamanouchi, T.: Aerosols in polar regions: A historical overview based on optical depth and in situ observations, J. Geophys. Res., 112, D16205, doi:10.1029/2007JD008432, 2007.

Toom-Sauntry, D. and Barrie, L. A.: Chemical composition of snowfall in the high Arctic: 1990-1994, Atmos. Envion., 36, 2683-2693, 2002.

Toyota, K., Kanaya, Y., Takahashi, M., and Akimoto, H.: A box model study on photochemical interactions between VOCs and reactive halogen species in the marine boundary layer, Atmos. Chem. Phys., 4, 1961-1987, doi:10.5194/acp-4-1961-2004, 2004.

Tuckermann, M., Ackermann, R., Göltz, C., Lorenzen-schmidt, H., Senne, T., Stutz, J., Trost, B., Unold, W., and Platt, U.: DOAS-observation of halogen radical-catalysed arctic boundary layer ozone destruction during the ARCTOC-campaigns 1995 and 1996 in Ny-Ålesund, Spitsbergen, Tellus, 49B, 533-555, 1997.

Vasilkov, A. P., Joiner, J., Haffner, D., Bhartia, P. K., and Spurr, R. J. D.: What do satellite backscatter ultraviolet and visible spectrometers see over snow and ice? A study of clouds and ozone using the A-train, Atmos. Meas. Tech., 3, 619-629, doi:10.5194/amt-3-619-2010, 2010.

Vogt, R., Crutzen, P. J., and Sander, R.: A mechanism for halogen release from sea-salt aerosol in the remote marine boundary layer, Nature, 383, 327-330, 1996.

Voulgarakis, A., Yang, X., and Pyle, J. A.: How different would tropospheric oxidation be over an ice-free Arctic?, Geophys. Res. Lett., 36, L23807, doi:10.1029/2009GL040541, 2009.

Wagner, T. and Platt, U.: Satellite mapping of enhanced BrO concentrations in the troposphere, Nature, 395, 486-490, 1998.

Wagner, T., Leue, C., Wenig, M., Pfeilsticker, K., and Platt, U.: Spatial and temporal distribution of enhanced boundary layer $\mathrm{BrO}$ concentrations measured by the GOME instrument aboard ERS2, J. Geophys. Res., 106, 24225-24235, 2001.

Wagner, T., Burrows, J. P., Deutschmann, T., Dix, B., von Friedeburg, C., Frieß, U., Hendrick, F., Heue, K.-P., Irie, H., Iwabuchi, H., Kanaya, Y., Keller, J., McLinden, C. A., Oetjen, H., Palazzi, E., Petritoli, A., Platt, U., Postylyakov, O., Pukite, J., Richter, A., van Roozendael, M., Rozanov, A., Rozanov, V., Sinreich, R., Sanghavi, S., and Wittrock, F.: Comparison of box-airmass-factors and radiances for Multiple-Axis Differential Optical Absorption Spectroscopy (MAX-DOAS) geometries calculated from different UV/visible radiative transfer models, Atmos. Chem. Phys., 7, 1809-1833, doi:10.5194/acp-7-1809-2007, 2007.

Wang, M. and Overland, J. E.: A sea ice free summer Arctic within 30 years?, Geophys. Res. Lett., 36, L07502, doi:10.1029/2009GL037820, 2009.

Wennberg, P.: Atmospheric chemistry - Bromine explosion, Nature, 397, 299-301, 1999.

Wesely, M. L.: Parameterization of surface resistances to gaseous dry deposition in regional-scale numerical models, Atmos. Environ., 23, 1293-1304, 1989.

Wessel, S., Aoki, S., Winkler, P., Weller, R., Herber, A., Gernandt, H., and Schrems, O.: Tropospheric ozone depletion in polar regions. A comparison of observations in the Arctic and Antarctic, Tellus, 50B, 34-50, 1998.

Wren, S. N., Kahan, T. F., Jumaa, K. B., and Donaldson, D. J.: Spectroscopic studies of the heterogeneous reaction between $\mathrm{O}_{3}(\mathrm{~g})$ and halides at the surface of frozen salt solutions, J. Geophys. Res., 115, D16309, doi:10.1029/2010JD013929, 2010.

Yang, X., Cox, R. A., Warwick, N. J., Pyle, J. A., Carver, G. D., O'Connor, F. M., and Savage, N. H.: Tropospheric bromine chemistry and its impacts on ozone: A model study, J. Geophys. Res., 110, D23311, doi:10.1029/2005JD006244, 2005.

Yang, X., Pyle, J. A., and Cox, R. A.: Sea salt aerosol production and bromine release: Role of snow on sea ice, Geophys. Res. Lett., 35, L16815, doi:10.1029/2008GL034536, 2008.

Yang, X., Pyle, J. A., Cox, R. A., Theys, N., and Van Roozendael, M.: Snow-sourced bromine and its implications for polar tropospheric ozone, Atmos. Chem. Phys., 10, 7763-7773, doi:10.5194/acp-10-7763-2010, 2010.

Yurganov, L. N.: Surface layer ozone above the Weddell Sea during the Antarctic spring, Antarctic Science, 2, 169-174, 1990.

Zeng, T., Wang, Y., Chance, K., Browell, E. V., Ridley, B. A., and Atlas, E. L.: Widespread persistent near-surface ozone depletion at northern high latitude in spring, Geophys. Res. Lett., 30(24), 2298, doi:10.1029/2003GL018587, 2003.

Zeng, T., Wang, Y., Chance, K., Blake, N., Blake, D., and Ridley, B.: Halogen-driven low-altitude $\mathrm{O}_{3}$ and hydrocarbon losses in spring at northern high latitudes, J. Geophys. Res., 111, D17313, doi:10.1029/2005JD006706, 2006.

Zhang, L., Moran, M. D., Makar, P. A., Brook, J. R., and Gong, S.: Modelling gaseous dry deposition in AURAMS: a unified regional air-quality modelling system, Atmos. Environ., 36, 537560, 2002.

Zhao, T. L., Gong, S., Bottenheim, J. W., McConnell, J. C., Sander, R., Kaleschke, L., Richter, A., Kerkweg, A., Toyota, K., and Barrie, L. A.: A three-dimensional model study on the production of $\mathrm{BrO}$ and Arctic boundary layer ozone depletion, J. Geophys. Res., 113, D24304, doi:10.1029/2008JD01063, 2008. 